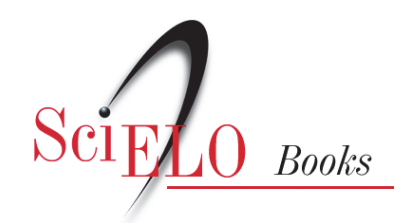

\title{
De portas abertas para o lazer
}

A cultura lúdica nas comunidades de bairro

\author{
Elaine Melo de Brito Costa Lemos \\ Eduardo Ribeiro Dantas \\ Cheng Hsin Nery Chao \\ orgs.
}

LEMOS, EMBC., DANTAS, ER., and CHAO, CHN., orgs. De portas abertas para o lazer: a cultura lúdica nas comunidades de Bairro [online]. Campina Grande: EDUEPB, 2009. 184 p. ISBN 978-85-

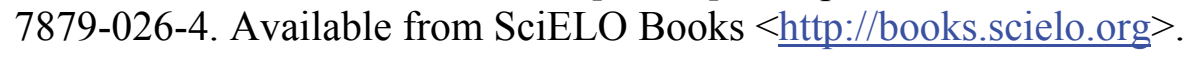

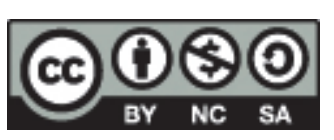

All the contents of this work, except where otherwise noted, is licensed under a Creative Commons Attribution-Non Commercial-ShareAlike 3.0 Unported.

Todo o conteúdo deste trabalho, exceto quando houver ressalva, é publicado sob a licença Creative Commons Atribuição Uso Não Comercial - Partilha nos Mesmos Termos 3.0 Não adaptada.

Todo el contenido de esta obra, excepto donde se indique lo contrario, está bajo licencia de la licencia Creative Commons Reconocimento-NoComercial-CompartirIgual 3.0 Unported. 


\section{De Portas Abertas para o Lazer}

A Cultura Lúdica nas
Comunidades de Bairro

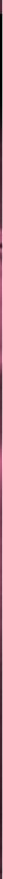

Elaine Melo de Brito Costa Lemos Eduardo Ribeiro Dantas Cheng 7 sin Nery Chao 


\section{De Portas \\ Abertas para o Lazer}

A Cultura Lúdica nas

Comunidades de Bairro 
Elaine Melo de Brito Costa Lemos

Eduardo Ribeiro Dantas

Cheng Hsin Nery Chao

(Organizadores)

\title{
De Portas \\ Abertas para o Lazer
}

A Cultura Lúdica nas Comunidades de Bairro

\author{
Seduepb \\ Campina Grande - PB \\ 2009
}




\title{
UNIVERSIDADE ESTADUAL DA PARAÍBA
}

\author{
Profa. Marlene Alves Sousa Luna \\ Reitora
}

Prof. Aldo Bezerra Maciel

Vice-Reitor

\section{Seduepb}

\section{Editora da Universidade Estadual da Paraíba}

\section{Diretor}

Cidoval Morais de Sousa

\section{Coordenação de Editoração \\ Arão de Azevedo Souza}

\section{Conselho Editorial}

Célia Marques Teles - UFBA

Dilma Maria Brito Melo Trovão - UEPB

Djane de Fátima Oliveira - UEPB

Gesinaldo Ataíde Cândido - UFCG

Inácia Sátiro Xavier de França - Ad hoc UEPB

José Lamartine da Costa Barbosa - UEPB

Joviana Quintes Avanci - FIOCRUZ

Rosilda Alves Bezerra - UEPB

Waleska Silveira Lira - UEPB

\author{
Editoração Eletrônica \\ Jefferson Ricardo Lima Araujo Nunes \\ Leonardo Ramos Araujo \\ Capa \\ Arão de Azevedo Souza \\ Comercialização e Divulgação \\ Júlio Cézar Gonçalves Porto \\ Zoraide Barbosa de Oliveira Pereira \\ Revisão Linguística \\ Elizete Amaral de Medeiros \\ Normalização Técnica \\ Elisabeth da Silva Araújo \\ Impressão \\ Center Gráfica Ltda.
}

Depósito legal na Biblioteca Nacional, conforme decreto nำ1.825, de 20 de dezembro de 1907. FICHA CATALOGRÁFICA ELABORADA PELA BIBLIOTECA CENTRAL - UEPB

306.481 .2

P842 De portas abertas para o lazer: a cultura lúdica nas comunidades de Bairro / Elaine Melo de Brito Costa Lemos, Eduardo Ribeiro Dantas, Cheng Hsin Nery Chao (Organizadores). - Campina Grande: EDUEPB, 2009.

184 p. : il.

ISBN - 978-85-7879-026-4

1. Lazer. 2. Campina Grande - Aspectos Sociais. 3. Campina Grande-Comunidades de Bairro. I. Lemos, Elaine Melo de Brito Costa. II. Dantas, Eduardo Ribeiro. III. Chao, Cheng Hsin Nery.

21. ed. CDD

EDITORA DA UNIVERSIDADE ESTADUAL DA PARAÍBA

Rua Baraúnas, 351 - Bodocongó - Bairro Universitário - Campina Grande-PB - CEP 58429-500

Fone/Fax: (83) 3315-3381 - http://eduepb.uepb.edu.br - email: eduepb@uepb.edu.br Todos os direitos reservados. A reprodução não-autorizada desta publicação, por qualquer meio, seja total ou parcial, constitui violação da Lei no 9.610/98.

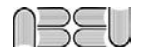

Editora filiada a ABEU 


\title{
Agradecimentos
}

\author{
Ao Ministério do Esporte \\ À Secretaria Nacional de Desenvolvimento \\ do Esporte e do Lazer \\ À Universidade Estadual da Paraíba \\ À Pró-Reitoria de Administração \\ À Pró-Reitoria de Finanças \\ À Editora Universitária \\ Aos membros do Grupo de Pesquisa Corpo, \\ Educação e Movimento
}




\section{Sumário}

Abrindo as portas da pesquisa: pressupostos teóricos e metodológicos

Elaine Melo de Brito Costa Lemos

A cultura lúdica enquanto estratégia de sobrevivência e resistência no bairro de

Apropriação e resignificação dos espaços nas

Pelo direito ao lazer: participação e mobilização social no bairro de Santa Rosa 
Estabelecendo relações entre as práticas e condições de lazer no bairro Jardim Borborema

Heluan Ruana Alves de Medeiros

Cheng Hsin Nery Chao

Tensões e contradições no cotidiano

lúdico do Catolé

Emília Amélia Pinto Costa da Silva

Eduardo Ribeiro Dantas

Pedregal, a dimensão educacional do lazer

165 contribuindo para uma nova perspectiva de vida

Tiago Lopes Bezerra

Cheng Hsin Nery Chao 


\title{
Abrindo as portas da pesquisa: Pressupostos teóricos e metodológicos
}

\author{
Elaine Melo de Brito Costa Lemos
}

O Ministério do Esporte a partir de sua Secretaria Nacional de Desenvolvimento do Esporte e do Lazer vem promovendo ações que visam a superar a carência de políticas públicas e sociais, no sentido de atender as crescentes necessidades e demandas da população por esporte recreativo e lazer, sobretudo daquelas em situações de vulnerabilidade social e econômica.

A Universidade Estadual da Paraíba - UEPB vem desde 2005, época em que se submeteu pela primeira vez ao Edital da Rede CEDES, apostando nos possíveis frutos desta parceria com o Governo Federal, através do Ministério do Esporte, que são vislumbrados a partir da consolidação de pesquisas, no campo do lazer, na Paraíba, que podem subsidiar diversas ações como, cursos de formação continuada e políticas de lazer que considerem a participação popular como um elemento de inovação em gestão pública.

Acompanhando a tendência de atenuação das condições de injustiça e exclusão social, a partir do esporte recreativo e do lazer, o Grupo de Pesquisa Corpo, Educação e Movimento - GCEM, do Departamento de Educação Física da Universidade Estadual da Paraíba - UEPB, propôs o desenvolvimento de uma investigação sobre a situação do lazer na cidade de Campina Grande - PB, considerando a Pesquisa de Infor- 
mações Básicas Municipais (MUNIC, 2003), a partir do universo das comunidades de bairro.

Neste processo, não podemos deixar de reconhecer a significativa participação dos professores do Departamento de Educação Física/ UEPB Eduardo Ribeiro Dantas, Maria Goretti da Cunha Lisboa e Jozilma de Medeiros Gonzaga que desde o início se dedicaram à construção do Projeto de Pesquisa e, posteriormente, em 2007, o Professor Cheng Hsin Nery Chao passou a integrar o Grupo de Pesquisa.

0 estudo entende comunidade de bairro o conjunto de entidades que abriga escolas, ONG's, as sociedades de bairro, etc, constituídas por atores sociais. Baseando-nos em Bauman (2003), a palavra comunidade não é compreendida pelo estudo de forma romântica no sentido da homogeneidade e do consenso, pois se constituída de seres humanos, a comunidade é por si mesma plural e paradoxal quando se trata dos interesses e necessidades individuais e coletivos.

A Prefeitura Municipal de Campina Grande possui uma regulação formal das demarcações dos bairros, porém os atores sociais, ou seja, os moradores constroem outras regulações, como serão abordadas nos capítulos, inclusive para o uso de espaços públicos de lazer, bem como, para incluir ou não moradores de outros segmentos territoriais dentro do próprio bairro para as decisões e reivindicações do mesmo.

As comunidades de bairro, no estudo, foram representadas, inicialmente, pela Associação Amigos de Bairro e a Escola Pública Municipal, e de acordo com a necessidade de cada bairro, outras entidades foram buscadas, como por exemplo, o Clube de Mães, Programa Saúde da Família, além dos próprios moradores. A nossa intenção de aproximarmos destas entidades comunitárias parte da percepção de que seus representantes, como presidentes, diretores e outros buscam em suas vivências dignificar a vida urbana com ações que traduzam o desenvolvimento do bairro, e consequentemente o desenvolvimento humano na experiência do lazer, educação, saúde e meio ambiente. Neste sentido, inspirados em Canclini (2008), compreendemos que as comunidades de bairro representam um lugar de elaboração de insatisfação, desejos e busca de comunicação com o poder público. 
Compreendendo o lazer como possibilidade de emancipação e desenvolvimento humano," ... ainda a participação cultural como uma das bases para a renovação democrática e humanista da cultura e da sociedade..." (Marcellino, 1995, p. 17) e o seu acesso, assim como ao esporte recreativo, como direito social, a pesquisa revelou-se um marco inicial das ações na Paraíba, do Centro de Desenvolvimento Científico e Tecnológico do Esporte e do Lazer, implantado na Universidade Estadual da Paraíba, construindo de um banco de dados referentes às temáticas do esporte e lazer que vislumbram a continuidade em pesquisas na área em foco, a exemplo, duas monografias de conclusão de curso, intituladas 'Lazer, trabalho e consumo na sociedade contemporânea' e 'A experiência estética da dança e os possíveis diálogos com as políticas públicas de lazer em Campina Grande-PB'. Além de duas pesquisas aprovadas com financiamento do Programa de Pesquisa - PROPESQ da Universidade Estadual da Paraíba intituladas 'Cultura de movimento em pauta: interfaces entre rádios comunitárias e políticas públicas de lazer' e 'A fruição estética da dança em diálogo com as políticas públicas de lazer na Paraíba'.

De acordo com a Política Nacional de Esporte - PNE, em consonância com a Política Nacional de Promoção de Saúde, o Esporte Recreativo e o lazer podem possibilitar experiências que ampliem a compreensão da saúde humana. Esta pesquisa, juntamente com as ações do Centro implantado, buscou estar em sintonia com tais políticas, ao criar um acervo de informações e documentações (depoimentos gravados em MP3 e em vídeos, entrevistas, fotografias, documentos oficiais) que caracterizam e podem conscientizar os diversos atores e entidades sociais sobre a importância das relações entre lazer, educação e saúde.

A cidade de Campina Grande não se destaca somente por seus eventos grandiosos como O Maior São João do Mundo, Micarande e Encontro da Consciência Cristã. É importante também situá-la como um pólo tecnológico reconhecido nacional e internacionalmente, tendo também duas Universidades públicas (Universidade Estadual da Paraíba - UEPB, Universidade Federal de Campina Grande - UFCG), Parque Tecnológico, bem como Universidades privadas, empresas como Alpargatas, Coteminas, dentre outras. 
Porém, Campina Grande vive problemas sócioculturais típicos de grandes metrópoles, como por exemplo, a ausência de incentivo à prática do esporte recreativo e do lazer no que se refere às políticas públicas para este fim, como também na sua relação com a educação e a saúde. Esse quadro foi confirmado pela Secretaria Municipal de Cultura, Esporte e Lazer, da cidade de Campina Grande-PB, ao mencionar que o Plano Participativo Orçamentário prevê uma verba destinada ao Esporte e Lazer, porém efetivamente não existindo perspectiva de nenhum repasse orçamentário para esta finalidade, de 2004 até 2006.

Numa discussão sobre gestão cultural da cidade, Coelho (2008, p. 9) é incisivo ao afirmar que a "cidade é a primeira e decisiva esfera cultural do ser humano", dentre suas justificativas estão a configuração da população mundial, onde mais da metade se localiza, vive em cidades. Da mesma forma, que nossas relações existenciais estão imbricadas na cidade, sejam elas de teor afetivo, social, econômico, lazer, dentre outras.

$\mathrm{O}$ autor segue ainda discutindo que a cidade possui um papel de destaque na definição das políticas públicas, e exemplifica com as ações da Agenda 21 para a Cultura e o Movimento Cidades e Governos Locais e Unidos. Afirma o autor, "nada mais é preciso para destacar o papel central da cidade na definição das políticas públicas” (2008, p. 9).

O que tem existido no Estado da Paraíba, especificamente, na cidade de Campina Grande, são ações isoladas que não caracterizam tampouco concretizam a compreensão e experiência ampla do lazer. Como trata Chemin (2008, p. 83), "a elaboração de políticas públicas de lazer requer uma interligação entre diversas outras áreas, entre elas a política urbana”. Para Canclini (2008), a urbanização torna-se desurbanizada para expandir-se irracionalmente e de forma especulativa trazendo consigo desequilíbrios e incertezas, sobretudo para aqueles socialmente menos favorecidos.

Perspectivando, então, ações mais amplas para o lazer, nosso estudo fundamentou-se também em Mascarenhas (2003), para quem o Lazer é compreendido "como fenômeno tipicamente moderno, resultante das tensões entre capital e trabalho, que se materializa como um tempo e espaço de vivências lúdicas, lugar de organização da cultura, perpassando por relações de hegemonia." 
A pesquisa apresentou como problemática central quais as interfaces entre lazer, educação e saúde reveladas no cotidiano das comunidades de bairro, na cidade de Campina Grande-PB? Foi estabelecido como Objetivo geral: diagnosticar e analisar as interfaces entre lazer, educação e saúde presentes no cotidiano das comunidades de bairro de Campina Grande/PB. Os objetivos específicos foram:

a) mapear os espaços e equipamentos de lazer nas comunidades de bairro, considerando aspectos quantitativos e qualitativos;

b) reconhecer e refletir sobre os eventos e as manifestações da cultura de movimento presentes nas comunidades de bairro, analisando a temporalidade da experiência do esporte recreativo e de lazer;

c) diagnosticar as condições ambientais no que se refere à prática do esporte recreativo e de lazer, focalizando sua relação com a saúde humana.

A relevância da pesquisa configura-se diante da necessidade e a urgência de estudos que revelem essas interfaces apontadas nos objetivos específicos, bem como, na relevância científica, tecnologia e de inovação em gestão pública, respectivamente, identifica-se na realização de uma investigação que considera o estudo desenvolvido pelo IBGE, através do MUNIC 2003. 0 estudo discute outras metodologias de ação e de gestão que podem ser elaboradas a partir dos resultados obtidos na vivência e o reconhecimento cotidiano das comunidades participantes do estudo. Consequentemente, o estudo aponta diferentes formas de gestão pública partindo de relatos, documentos e experiências dos atores sociais, e não somente de uma imposição ou ação linear governamental.

Quanto ao impacto social, pretendíamos a partir do Projeto justamente uma participação efetiva da comunidade no planejamento e execução de suas atividades de lazer. Isso corresponde dizer que se almeja, assim como Paulo Freire (2005), conscientizar os atores sociais tirando-os da opressão estrutural e de políticas assistencialistas.

Espera-se que a partir desta, ações possam ser delineadas no que se refere à orientação e promoção da prática do esporte recreativo e 
de lazer com vistas a uma educação em saúde, bem como resignificar os espaços de lazer nas comunidades de bairro, como também, a administração pública da cidade de Campina Grande possa se sensibilizar a uma gestão participativa com a sociedade no que se refere às políticas intersetoriais, especialmente as abordadas nesse estudo: urbana, educacional, saúde, lazer e cultura.

Almeja-se, ainda, que os atores sociais das comunidades de bairro investigadas, de áreas urbanas da cidade de Campina Grande, compreendam-se como participantes ativos das ações do seu cotidiano, exercendo sua cidadania no que diz respeito aos direitos e cuidados com o patrimônio público.

Considerando os resultados do IBGE a partir do MUNIC (2003), atingimos os seguintes resultados: 1 . identificadas e registradas a quantidade e a qualidade dos espaços e equipamentos de lazer existentes em sete comunidades de bairro, em Campina Grande/PB; 2. identificados e registrados os eventos de lazer, as manifestações da cultura de movimento, bem como a temporalidade em que ocorrem tais vivências nas sete comunidades de bairro; 3. identificadas e registradas as condições ambientais em que são realizadas as práticas do esporte recreativo e de lazer nas sete comunidades de bairro inseridas no estudo, considerando os indicadores de saúde pública da cidade.

No que se refere ao aspecto metodológico, a pesquisa caracterizouse como descritiva, d4o tipo estudo de campo, realizada em sete comunidades de bairro de Campina Grande-PB. 0 grupo investigado foi composto pelas comunidades associadas à Sociedade Amigos de Bairro - SAB dos seguintes bairros (Bodocongó, Catolé, Jardim Borborema, José Pinheiro, Malvinas, Pedregal e Santa Rosa) que abrigam escolas públicas municipais que oferecem ensino fundamental, tendo como base os dados do INEP.

Apesar de refletirmos, no estudo, parte do cotidiano dos bairros não estamos de forma alguma desconectando suas relações numa discussão ampla de políticas públicas intersetoriais na cidade de Campina Grande. 0 olhar particular, singular para cada um deles desponta a pluralidade da cidade, mas como trata Canclini (2008, p.21), não há 
saberes totalizadores, "nem o prefeito da cidade, nem o melhor especialista em planejamento urbano tem uma visão em profundidade do conjunto".

A escolha pela escola pública reflete uma opção política do Grupo de Pesquisa, por entendermos a responsabilidade social da pesquisa científica frente ao reconhecimento e valorização do espaço público. A delimitação do grupo investigado deve-se ao fato do município não oferecer ensino médio. Da mesma forma, entendemos que o público destas séries escolares, se comparado ao público da educação infantil, possuiria melhores condições de responder sobre o seu cotidiano, caso fosse necessário.

As pesquisas descritivas têm como objetivo principal a descrição das características de determinada população ou fenômeno, além do estabelecimento de relações entre determinadas variáveis (GIL, 2002). Compreendemos que uma pesquisa que busca revelar as interfaces entre Lazer, Saúde e Educação em comunidades de bairro de Campina Grande-PB, insere-se em tal classificação. Além disso, muitos estudos de campo podem ser classificados como pesquisas descritivas, como trata o autor supracitado.

A opção pelo estudo de campo se deu em virtude da pesquisa ser desenvolvida por meio de diferentes técnicas de coleta de dados, entre elas a observação direta das atividades do grupo investigado, assim como entrevistas com informantes para captar suas explicações e interpretações do que ocorre no grupo, além de outros procedimentos como a análise de documentos, a utilização de filmagens e fotografias. A ênfase é colocada na profundidade da descrição e não na sua precisão estatística, afirma Gil (2002).

De acordo ainda com Gil (2002), os Estudos de Campo iniciam-se, na maioria das vezes, com o plano de trabalho bem geral, levando em consideração muito mais o objetivo da pesquisa do que a definição de procedimentos. Mesmo assim, o autor sugere os seguintes procedimentos na coleta de dados: a) buscar apoio das lideranças locais; b) aliar-se a pessoas ou a grupos que tenham interesses na pesquisa; c) fornecer aos membros da comunidade as informações obtidas; d) preservar as identidades dos respondentes. 
Dessa forma, na coleta de dados dessa pesquisa, consideramos tais procedimentos metodológicos, a partir da adequação das diversas fases da pesquisa às etapas necessárias à implantação da infraestrutura física do Núcleo.

O estudo de campo requisitou a utilização de diversos instrumentos de pesquisa, como entrevista semiestruturada e escalas de observação. A análise dos dados na pesquisa de campo foi qualitativa, em decorrência da utilização das técnicas de coleta de dados. Baseando-nos em Gil (2002), o processo de análise qualitativa foi realizado através de uma sequência de atividades: $1^{\circ}$ - Redução dos dados; $2^{2}$ - Categorização e interpretação dos dados; $3^{\circ}$ - Redação do relatório final.

Considerando os aspectos de aplicabilidade, a pesquisa foi viável por partir de um banco de dados produzido pelo IBGE (MUNIC 2003) que aponta elementos quantitativos do cenário do esporte recreativo no Brasil. Considerando tal estudo, essa pesquisa apresenta desdobramentos principalmente no âmbito qualitativo e do ponto de vista da comunidade que podem ser utilizados na gestão de políticas públicas locais. Tal proposição remete-se às inovações em gestão pública, uma vez que, integra a comunidade nas discussões e decisões no campo do esporte recreativo e lazer.

A pesquisa foi efetivada a partir de: 1 . contatos com lideranças comunitárias, diretores de escolas, moradores de bairro, dentre outros a partir da singularidade da comunidade; 2. definição dos espaços significativos da vivência do esporte recreativo e de lazer em cada comunidade; 3. pesquisa de campo com envolvimento dos bolsistas de iniciação científica, juntamente com os professores pesquisadores, nas comunidades para realização de registro fotográfico, filmagens, entrevistas e levantamento documental.

Inspirados no cotidiano das comunidades de bairro que constituíram a pesquisa, a relação entre a cidade, cultura e lazer, em Campina Grande, dialogamos com Coelho (2008) para expressarmos que tal relação pode ser formulada numa perspectiva de reinventar o cotidiano considerando as experiências das comunidades de bairro que juntas configuram a cidade. Campina Grande precisa renovar e expandir seus recursos culturais e de lazer, sobretudo as danças, as festas, que são 
símbolos culturais da cidade, mas sendo fundamental que tais recursos tenham uma vivência cotidiana para que se crie uma malha cultura sólida, expressão do autor.

Uma estratégia possa ser uma ação/intervenção criativa que relacione cultura, lazer e os problemas urbanos a partir do potencial cultural de cada bairro, garantindo a população e ao turista, em geral, a apreciação das danças, nos ensaios das quadrilhas, dos bumba-meuboi, as visitas ao Museu de Futebol, as festas juninas, tornando-se sustentável o processo cultural sem perder de vista que toda a sociedade também tem seu papel em reorganizar o lazer e a cultura, na cidade de Campina Grande, para que se torne política pública de lazer, cultural e urbana de proximidade.

\section{Referências}

BAUMAN, Z. Comunidade: a busca por segurança no mundo atual. Rio de Janeiro: Jorge Zahar Ed., 2003.

CANCLINI, N. G. Imaginários culturais da cidade: conhecimento/espetáculo/desconhecimento. In: COELHO, T. (Org.). A cultura pela cidade. São Paulo: Iluminuras: Itaú Cultural, 2008.

CHEMIN, B. F. Políticas públicas do lazer: o papel dos municípios na sua implementação. Curitiba: Juruá, 2008.

COELHO, T, A cidade e os avatares da cultura. In: COELHO, T. (Org.). A cultura pela cidade. São Paulo: Iluminuras: Itaú Cultural, 2008.

FREIRE, P. Pedagogia do oprimido. 46. ed. Rio de Janeiro: Paz e Terra, 2005.

GIL, A. C. Pesquisa social. Cortez: São Paulo, 2002. 
MARCELLINO, N. C. A ação profissional no lazer, sua especificidade e seu caráter interdisciplinar. In: MARCELLINO, N. C. (Org). Lazer: Formação e atuação profissional. Campinas, SP: Papirus, 1995.

MASCARENHAS, F. O pedaço sitiado: cidade, cultura e lazer em tempos de globalização. Revista brasileira de ciências do esporte. Campinas, v. 24, n. 3, p. 7-210, maio 2003.

MUNIC - Pesquisa de Esporte 2003. Coordenação de População e Indicadores Sociais. Rio de Janeiro: IBGE, 2006. 


\title{
A cultura lúdica enquanto estratégia de sobrevivência e resistência no bairro de Bodocongó
}

\author{
Nayara Suênia de Oliveira \\ Eduardo Ribeiro Dantas
}

A intersetorialidade é um princípio de gestão pública que vem sendo bastante discutido e incentivado hoje em dia, principalmente quando a intervenção do Estado se dá em campos multidisciplinares como o do lazer. Prova disso, são os resultados da pesquisa que ora apresentamos, frutos de uma Chamada Pública do Ministério do Esporte, cujo objetivo maior foi estimular a produção do conhecimento no campo da gestão esportiva, tendo como um de seus eixos principais, a integração de políticas públicas de esporte recreativo e de lazer a outras políticas de desenvolvimento social, numa perspectiva de gestão intersetorial.

Do ponto de vista jurídico-administrativo, a gestão intersetorial do lazer vem sendo abordada por autores como Chemin (2007), para quem a efetivação do direito ao lazer à população brasileira, não depende apenas de uma política específica promovida pelo Estado, mas da elaboração e consolidação de diversas políticas públicas em áreas correlatas, tais como o desenvolvimento urbano.

Cada vez mais debatida no âmbito acadêmico e social, a importância do espaço urbano para o lazer vem sendo discutida já, há algum tempo, na Educação Física brasileira. Marcellino (2002), por exemplo, ao tratar de questões que envolvem a democratização cultural no país, afirma que para democratizarmos o lazer, precisamos antes de qual- 
quer coisa, democratizar o espaço urbano, já que no cotidiano da população, o espaço para o lazer é necessariamente o espaço da cidade.

Espaço este, que vem sendo vitimado pelo crescimento urbano desordenado e pela especulação imobiliária, o que na visão do autor, reduz não só os locais para a vivência dos interesses físicos do lazer, como também, compromete a estética e as possibilidades de contemplação da cidade (MARCELLINO, 2002).

Diante desse quadro, o planejamento das cidades brasileiras emerge tanto como uma necessidade da população, no tocante às possibilidades de experiências lúdicas, quanto um desafio a ser enfrentado pelo poder público, quando pensamos especificamente em políticas públicas de esporte recreativo e de lazer.

Necessidade, pelo fato da experiência do lazer está intimamente relacionada à experiência da cidade e, consequentemente, ao seu planejamento. Desafio, porque as cidades brasileiras têm como característica histórica, justamente a falta de planejamento, razão de muitos de seus problemas atuais (CHEMIN, 2007).

Um outro aspecto que gostaríamos de destacar no momento, em relação ao planejamento de nossas cidades, é a possibilidade de nos depararmos com certos modelos de urbanismo, que não possibilitam a apropriação corporal dos espaços urbanos, por parte da população em geral. Ou, quando assim não o fazem, favorecem a redução das possibilidades de experiência corporal dos cidadãos, às vivências do esporte institucionalizado, o que, no nosso entendimento, torna-se tão problemático quanto a primeira hipótese.

Em síntese, o que acontece nesses casos, é que, quando a cidade se oferece à nossa apropriação corporal, não sendo apenas mais um cenário para o olhar do turista, o faz na perspectiva da lógica esportiva, onde o que importa é o rendimento e a utilidade da gestualidade humana.

Partilhando da ideia discutida por Soares (2001), para quem a arquitetura é um caso particular de linguagem e uma possibilidade concreta de materialização de discursos, questionamos não só a falta de planejamento urbano por parte do poder público, em relação à vivên- 
cia da cultura lúdica da população, mas também, um tipo de planejamento que não leva em conta os desejos e as práticas diárias dos moradores das cidades brasileiras, negando a experiência corporal urbana em nome da estética do espetáculo ${ }^{1}$, ou privilegiando os códigos padronizados do esporte performance, em detrimento das mais diversas manifestações culturais, vividas em ruas e esquinas de todo o país.

Compreendemos que as políticas públicas intersetoriais de lazer e desenvolvimento urbano, devem rever alguns conceitos quanto ao planejamento das cidades, principalmente no tocante às possibilidades de experiências corporais da população. Um primeiro ponto, a ser levado em conta, é o processo de espetacularização das cidades contemporâneas, que está diretamente relacionado ao empobrecimento da experiência urbana corporal.

A redução da ação urbana, ou seja, o empobrecimento da experiência urbana pelo espetáculo leva a uma perda da corporeidade, os espaços urbanos se tornam simples cenários, sem corpo, espaços desencarnados (BRITO; JACQUES, 2008, p. 80).

0 urbanismo atual, pensado a partir de uma política pública intersetorial de lazer, não pode perder de vista a condição corporal do cidadão. A separação do espaço urbano do seu caráter experiencial e corporal pode torná-lo uma experiência desastrosa (BRITO; JACQUES, 2008).

Acontece que aqueles que pensam a cidade, que projetam e implementam políticas públicas urbanas, vêm desconsiderando sua dimensão de espaço público, destinada ao encontro e ao convívio social, efetivados nas relações corporais dos cidadãos. Desse modo, as diversas formas de habitar o espaço e viver o tempo das cidades, que as caracterizam e as constituem simultaneamente, tornam-se invisíveis, ou melhor, são invisibilizadas pelos processos hegemônicos de regulação e administração urbana (SILVA; FONSECA, 2007).

1 Processo denunciado nos anos 60, por um grupo de ativistas políticos, artistas e intelectuais, como Guy Debord, que criticavam um certo tipo de planejamento urbano, definido previamente sem a participação ativa dos cidadãos. Planejamento este, que estático, levava as cidades a se tornarem verdadeiros espetáculos para turistas, reduzindo com isso, sua apropriação por parte dos moradores (JACQUES, 2003). 
Entendemos que maiores possibilidades de apropriação corporal da cidade podem gerar não só novas formas de uso da mesma, por parte da população, mas reverterem-se também, em novas reflexões e intervenções políticas do poder público, mais próximas aos interesses dos cidadãos.

A cidade, portanto, não só deixa de ser cenário quando é praticada mas, mais do que isso, ela ganha corpo, e tornando-se "outro" corpo. Dessa relação entre o corpo do cidadão e esse "outro corpo urbano" pode surgir uma outra forma de apreensão urbana, e, consequentemente, de reflexão e de intervenção na cidade contemporânea (BRITO; JACQUES, 2008, p. 81).

Por isso, é importante questionarmos as apropriações corporais efetivadas no cotidiano lúdico das nossas cidades, de forma a identificarmos caminhos alternativos traçados pelos corpos dos cidadãos, que resistindo ${ }^{2}$ tanto ao processo de espetacularização, quanto à homogeneização esportiva dos tempos e espaços urbanos - segundo ponto da nossa problemática - possam ser considerados pelos gestores públicos, enquanto elementos necessários à formulação e consolidação de políticas participativas de lazer.

Em Bodocongó, bairro da cidade de Campina Grande, situado no interior da Paraíba, a apropriação do espaço urbano, nas experiências lúdicas dos seus moradores, se dá em meio a condições ambientais muitas vezes adversas, revelando a necessidade de políticas públicas que realmente efetivem o direito ao lazer e não apenas ofereçam estratégias de sobrevivência à população ${ }^{3}$.

2 No sentido conferido por Certeau (1998), quando discute a ideia de "tática", enquanto prática antidisciplinar que subverte as estratégias de poder, responsáveis pelo controle e organização do espaço social.

3 Novamente nos inspiramos nas ideias de Certeau (1998), para quem a noção de "estratégia" remete ao conjunto de operações utilizadas para organizar e controlar o espaço social. Quando falamos em "estratégias de sobrevivência", relacionadas às políticas públicas de esporte recreativo e de lazer, estamos nos referindo a intervenções do tipo "pão e circo", recorrentes nas administrações públicas brasileiras, que ao invés de políticas sociais concretas, agem maquiando os problemas existentes. 


\section{Bodocongó: a vida ao redor do açude}

O bairro de Bodocongó tem como principal referência o açude do qual recebe o nome, construído em 1917 por conta da escassez de água, na região, uma vez que outros açudes da cidade já não estavam suprindo as necessidades da população. Imortalizado na letra da música de Humberto Teixeira e Cícero Nunes e popularizado pelas vozes de Helena de Lima e Elba Ramalho, o açude de Bodocongó vive hoje uma dura realidade, já que se encontra bastante poluído, em virtude do lançamento de esgoto doméstico, industrial e hospitalar em suas águas, além da utilização agressiva da própria população ${ }^{4}$.

Ao seu redor, o bairro continua crescendo, muitas vezes de forma desordenada. Segundo dados do Instituto Brasileiro de Geografia e Estatística - IBGE (2002), Bodocongó é um dos maiores bairros periféricos de Campina Grande, tendo uma população que ultrapassa atualmente a quantidade de 13 mil habitantes.

O crescimento desordenado do bairro faz com que os seus limites territoriais sejam confusos até mesmo para a população que o habita, visto que através de nossa pesquisa de campo, pudemos identificar visões distintas sobre sua área geográfica.

A presidente da Sociedade Amigos do Bairro - SAB Bodocongó, por exemplo, não reconhece a "Vila dos Teimosos" ${ }^{5}$, como sendo parte do bairro. Diferentemente de moradores dessa comunidade que, quando questionados sobre a que bairro pertenciam, não hesitaram em apontar o bairro de Bodocongó.

Se levarmos em conta a lei municipal de divisão de bairros $\mathrm{n}^{\mathrm{o}}$. 1.542/87, a "Vila dos Teimosos" se encontra nos limites do bairro de

4 Apesar de ser objeto de preocupação e investimentos tanto do poder público quanto da sociedade civil organizada, o açude de Bodocongó encontra-se hoje em uma situação delicada. Segundo recente pesquisa, as águas do açude de Bodocongó não atendem aos padrões da Resolução 357/05 do Conselho Nacional do Meio Ambiente - CONAMA, revelando-se impróprias para usos múltiplos, como irrigação e lazer. Segundo os autores do estudo, as principais fontes de poluição de suas águas são: lançamento de esgoto, águas de lavagem de carros, matadouro clandestino e disposição inadequada de resíduos sólidos (CARVALHO; MORAES NETO; LIMA, et al, 2008).

5 Comunidade ribeirinha que recebeu este nome justamente por ignorar as possibilidades de aumento do nível das águas do açude Bodocongó, preferindo permanecer no local mesmo com o risco de inundações. 
Bodocongó, com os bairros Novo Bodocongó e Universitário, sendo que, por estarem situadas às margens do açude, boa parte de suas moradias encontram-se dentro dos limites territoriais de Bodocongó.

Prova de que um mapa urbano, mesmo que oficial, não pode ser tomado como única referência na determinação de uma comunidade, já que não corresponde, de forma absoluta, às diversas dinâmicas territoriais e sociais presentes no local que representa. Em Bodocongó, bairro constituído através da incorporação de conjuntos e invasões, a questão territorial se apresenta como um dos primeiros desafios na elaboração de políticas sociais que atendam aos interesses de sua população.

Isso porque os canais institucionais que a representam, como a SAB Bodocongó, muitas vezes, utilizam critérios territoriais para essa função, de forma que qualquer entendimento diferente sobre onde começa e termina o bairro, pode fazer com que parte dos seus moradores fiquem desassistidos, ou, na melhor das hipóteses, tenham outra representação.

No caso da "Vila dos Teimosos", por exemplo, o não reconhecimento da presidente da SAB local, em relação ao seu pertencimento ao bairro de Bodocongó, faz com que os moradores daquela comunidade não possam reivindicar melhorias para sua área, a partir deste canal institucional, já que só participam das suas reuniões, os moradores que, na visão dos gestores, fazem parte do bairro.

No nosso entendimento, qualquer ideia de divisão dentro do bairro, seja ela territorial ou social, não favorece em nenhum momento a implantação de políticas públicas de esporte recreativo e de lazer para a comunidade, já que diminui as possibilidades de participação e organização popular, além de aumentar os conflitos internos, reduzindo a força de reivindicação da população.

Considerando a falta de saneamento básico e as péssimas condições de moradia dessa comunidade, essa situação só torna ainda mais difícil a vida às margens do açude Bodocongó. Sem um sistema de esgotamento sanitário adequado e ruas calçadas para um melhor acesso do sistema de coleta de lixo, entre outros problemas estruturais semelhantes, soa utópico para muitos do próprio local, a reivindicação de 
políticas públicas de esporte recreativo e lazer para os moradores da "Vila dos Teimosos".

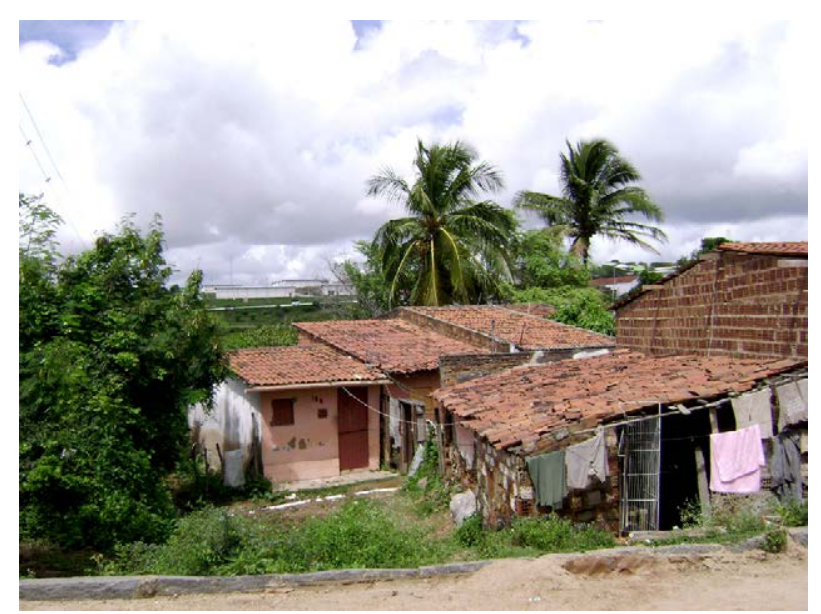

Imagem 01: "Vila dos Teimosos": sobrevivência às margens do açude de Bodocongó

Fonte: Arquivos do GCEM

Apesar disso, a comunidade vem sendo atendida, juntamente aos demais moradores do bairro, por políticas sociais de esporte e lazer, como a da Universidade Estadual da Paraíba - UEPB. Através de programas e projetos que atendem principalmente crianças e idosos da região, de forma gratuita, a UEPB vem suprindo algumas carências no tocante ao esporte recreativo e ao lazer.

Somente um de seus projetos, atende cerca de 340 pessoas de toda a cidade, sendo que em razão da UEPB estar localizada em Bodocongó, o número de moradores desse bairro corresponde a aproximadamente um terço dos participantes, o que significa uma boa frequência dos moradores de Bodocongó em relação à população dos demais bairros, mas ainda assim, é insuficiente frente a quantidade de moradores dessa área.

A Universidade Federal de Campina Grande - UFCG, outra instituição educacional situada próxima a Bodocongó, também já chegou 
a oferecer ações de esporte e lazer para a comunidade, o que favorecia os moradores do bairro. Atualmente, porém, ela não dispõe de nenhum projeto ou programa do tipo, abertos à comunidade em geral, pois tudo é voltado para a comunidade acadêmica.

Alega-se, por parte da administração do setor, existirem poucos equipamentos e muitos discentes na instituição, o que inviabiliza a divisão do espaço. Compreendemos que pela sua localização privilegiada e sua função social junto à sociedade brasileira, as universidades públicas citadas, constituem-se em ótimas possibilidades para que a população de Bodocongó possa ter efetivado o seu direito ao lazer.

É preciso, porém, que essas instituições tornem-se mais acessíveis à comunidade em geral, não se fechando em um academicismo perverso, que vê o mundo fora das universidades apenas como laboratório de pesquisas ou campo de estágios para seus professores e alunos.

Uma outra ação que atinge os moradores do bairro, é o Programa de Erradicação do Trabalho Infantil - PETI, desenvolvido pela Secretaria Municipal de Ação Social - SEMAS. O PETI atende crianças e adolescentes com idade escolar entre 7 a 15 anos, oferecendo a prática de atividades esportivas em horário contrário ao das aulas. Assim como no projeto existente na UEPB, estar matriculado e frequentar a escola são critérios utilizados para a entrada e permanência dos alunos no programa.

O lazer, tido como direito social, é entendido por nós como meio para o alcance da cidadania. Mas, para que possamos ter efetivamente o lazer como direito constituído, são necessárias políticas públicas que, além da gratuidade e qualidade, não estabeleçam tantas barreiras para a participação da população, tornando-se mais acessíveis.

Entendemos que a criação de critérios positivos para essa participação, como a otimização da vivência escolar, são ações intersetoriais necessárias à educação da população. Queremos alertar, porém, para a necessidade de pensarmos em políticas públicas de esporte recreativo e lazer que estejam ao alcance daqueles que não se encontram no processo de escolarização, já que estes são fenômenos, também, importantes para a educação da população. 
Programas gratuitos, como o "Campina Bem-Estar”, da Prefeitura Municipal de Campina Grande, que funcionava no bairro, realizando um trabalho de aferição da pressão arterial, peso e altura, das pessoas que caminhavam próximo ao açude. Programa este, que foi suspenso há pouco tempo, já que segundo uma de nossas entrevistadas, pessoas da própria comunidade danificaram o ponto de apoio que servia para a sua realização.

De acordo com Suassuna, Almeida, Freire e Roquete (2007), para que o desenvolvimento de ações sociais nos municípios ocorra, fazse necessário estabelecer políticas públicas não só de governo, mas principalmente de Estado, que não venham a acabar nas mudanças de gestão. Consideramos, ainda, que a participação popular é de extrema importância para que isso ocorra, seja colaborando com a elaboração e efetivação de novas propostas, ou pelo menos respeitando o patrimônio público.

No caso da participação da SAB e de outros grupos da sociedade organizada de Bodocongó, é importante o reconhecimento das ações que se desenvolvem no bairro, para que se possa orientar a população e exigir políticas públicas de qualidade, que possibilitem a transformação social e não estejam dentro da lógica do "pão e circo", enquanto estratégias de controle da população.

Situação que no caso de Bodocongó se mostrou mais complicada, como veremos a seguir, já que os gestores entrevistados não reconheceram nenhuma das ações e espaços públicos citados anteriormente, enquanto possibilidades de experiências de lazer dos moradores do bairro.

\section{Participação e organização popular em Bodocongó}

O movimento comunitário começa a surgir de forma mais organizada em Campina Grande, no ano de 1958, quando uma espécie de Conselho Comunitário é criado, tendo como objetivo conscientizar a comunidade dos seus problemas cotidianos. A partir daí, as Sociedades de Amigos de Bairro - SABs, são criadas e se proliferam, inspiradas 
na experiência organizacional de estados como São Paulo, onde a participação política comunitária vinha tendo sucesso (SOUSA, 2006).

Tendo como objetivo reivindicar do poder público melhorias em seus bairros, as SABs de Campina Grande passam a ser coordenadas em 1964, em pleno regime militar, pela União Campinense de Equipes Sociais - UCES, órgão que ainda hoje coordena, orienta e fiscaliza as atividades das entidades a ele associadas, no intuito de facilitar a reivindicação popular na cidade.

Dentro desta visão, a união das SABs constituiu-se num instrumento poderoso de reivindicação popular, exigindo uma equidade social para todos os subúrbios, desde o Bairro das Nações até a recém-nascida Vila dos Teimosos em Bodocongó (SOUSA, 2006).

Em Bodocongó, uma das principais instituições representantes da comunidade, junto à esfera pública, é a SAB local. Fundada há mais de trinta anos, possui atualmente cerca de 600 sócios, participantes da entidade.

Segundo seu estatuto geral (UCES, 2009), as SABs não devem ter preconceito de raça, cor, opção sexual, credos religiosos, nem tampouco, favorecer partidarismos políticos. Acontece, porém, que seguindo a tradição histórica de sua constituição no país, onde muitas vezes eram transformadas em currais eleitorais de políticos populistas, as SABs de Campina Grande ainda deixam as questões político-partidárias se sobreporem aos interesses comunitários.

Vê-se, em todos os recantos do município, um atrelamento dos movimentos comunitários com as autoridades municipais, através de empreguismo ou qualquer tipo de dependência, tirando a característica principal de um movimento independente (SOUSA, 2006).

No bairro de Bodocongó, as questões político-partidárias fizeram com que o campeonato de futebol promovido pela sua $\mathrm{SAB}$, fosse levado para outro local. Esse campeonato era um dos mais bem sucedidos projetos de esporte e lazer desenvolvidos para a comunidade, que 
com a sua retirada, ficou sem nenhum evento do tipo, cuja participação masculina era muito forte.

Segundo Sousa (2006), as questões políticas fazem com que muitas vezes o desejo de ser membro de uma SAB, seja fruto de uma maior facilidade em conseguir um emprego para si ou para os seus familiares. Ainda de acordo com o autor, o trabalho de gestão das SABs deveria ser remunerado, para diminuir a vinculação e, consequentemente, a dependência política dessas instituições junto aos órgãos públicos.

E não são só os gestores das SABs que frequentemente desconsideram a independência política do trabalho comunitário. Questionada sobre a parceria com o Clube de Mães, situado ao lado da SAB Bodocongó, sua vice-presidente revela como as questões político-partidárias podem atrapalhar, ou não, o funcionamento dessas entidades.

Bem é só vizinho, mas quando elas vêm pedir alguma coisa que a gente pode servir, a gente contribui da mesma forma. Agora, o pessoal assim... o pessoal geralmente tem um entendimento político diferenciado, coisa que a gente não faz. A gente não faz diferença política. Mas sempre a presidente de lá tinha uma rixa política, mas a gente nunca teve não, porque a gente tá aqui para servir (Vice-presidente da $S A B$ Bodocongó).

Outro fator que pode comprometer o bom funcionamento dessas instituições, é a falta de envolvimento da população. Segundo Sousa (2006), as assembleias das SABs só conseguem reunir muita gente, quando o debatedor é uma "estrela". De acordo com o autor, a participação da comunidade nas SABs é muitas vezes comprometida, pelo pensamento de que ela é uma prestadora de serviços gratuitos da comunidade, de responsabilidade única de sua direção. Entendemos que somente com a participação de todos, é que há força para reivindicação junto aos governos.

A população deve se conscientizar de que o trabalho da SAB é um trabalho que deve ser executado por todos e não especificamente pelos seus Diretores, pois todos juntos constituem-se os organizadores do movimento. A SAB é intermediária entre as rei- 
vindicações comunitárias e os órgãos públicos e não se devem assumir determinadas tarefas que a comunidade não delegou poderes para poder resolvê-las (SOUSA, 2006).

Enquanto instituições mediadoras entre a população e o poder público, as SABs devem defender os interesses de suas comunidades. Em Campina Grande, um espaço onde isso pode ocorrer de forma mais efetiva, são as reuniões do Orçamento Participativo, que segundo Pinto (2008), constitui-se numa estratégia fundamental para as políticas sociais, já que reflete as reais prioridades dos municípios.

Através do Orçamento Participativo, por exemplo, as principais reivindicações dos moradores de Bodocongó, com relação ao esporte recreativo e ao lazer, chegaram às mãos da administração pública, via requerimentos intermediados pela $\mathrm{SAB}$ do bairro. Dentre as reivindicações mais recorrentes, podemos encontrar uma pista de caminhada e um campinho de areia, além de aulas de dança de salão.

É bem verdade que a participação popular e as reivindicações via Orçamento Participativo não são garantias de que as demandas da população venham a ser atendidas. A gestora da SAB local, alega já ter procurado o setor público para fazer algumas reivindicações, mas que nada foi atendido. É preciso então, que acompanhando a organização popular, haja mais "vontade política" para que as questões do esporte recreativo e do lazer sejam atendidas.

Na Escola Municipal de Ensino Fundamental Padre Antonino, outra instituição visitada por nós, que existe desde 1989 e possui, hoje em dia, um número de 518 alunos, as intervenções do poder público também são limitadas. Assim como ocorre com a SAB local, suas parcerias são feitas em grande parte com moradores do bairro, que voluntariamente ajudam em suas atividades ou fazem doações. Em relação ao esporte recreativo e ao lazer, existe um professor voluntário, na escola, que ministra aulas de capoeira para os alunos.

É interessante notarmos que suas reivindicações são de certa forma atendidas pela administração pública, menos no caso da quadra da escola, que segundo sua diretora, encontra-se abandonada pelo poder público. 
Nós só temos aí um esqueleto de quadra. É uma quadra de areia, mas de tanto... Há tanto tempo que tá aí e não foi mais preenchida que tá cheia de buracos. Eu já pedi pra secretaria vim preencher, mas até agora nada (Diretora da Escola Padre Antonino).

A ausência ou mesmo as limitações do poder público em atender as demandas lúdicas da população do bairro, fazem com que os seus moradores procurem outras alternativas para a vivência do esporte recreativo e do lazer. Vivências estas, nem sempre realizadas em locais adequados, do ponto de vista da integridade e da dignidade do ser humano, mas certamente vividas com muito prazer e alegria.

\section{"Felizes em Bodocongó": a cultura lúdica e a apropriação do espaço urbano}

A experiência lúdica vivida em Bodocongó, cantada nos versos da música que mencionamos anteriormente sobre o açude, mostra-nos que a vivência do esporte recreativo e do lazer, não depende da quantidade ou mesmo da qualidade de espaços e equipamentos específicos, construídos para este fim.

Eu fui feliz lá no bodocongó

Com meu barquinho de um remo só

Quando era lua

Com meu bem

Remava à toa

Ai ai ai que coisa boa

Lá no meu Bodocongó

(BODOCONGó - Humberto Teixeira e Cícero Nunes)

Não queremos com isso, desautorizar ou defender um espontaneísmo na formulação de políticas sociais de esporte recreativo e de lazer, que envolvem a infraestrutura do local. Estamos apenas alertando que, nem sempre a construção de certos equipamentos específicos, 
como quadras e ginásios esportivos, resolve os problemas da população neste setor, funcionando, em muitos casos, mais como propaganda de governo.

Até mesmo porque, a cidade é apropriada pelos seus moradores de formas distintas ao que foi planejada, tornando-se o que Certeau (1998) chamaria de "lugar praticado", organizado pelas "táticas" cotidianas, ou seja, o espaço criado por movimentos que fogem ao controle total das estratégias de poder ${ }^{6}$.

Um exemplo mais prosaico, mas que talvez facilite $o$ entendimento da dinâmica descrita por Certeau, é a relação de um morador com sua moradia. Esta, planejada em algum escritório de arquitetura, prevê um ambiente, conforme as intenções do arquiteto, com uma sala, dois quartos, uma cozinha e um banheiro. Contudo, o habitar do morador é um fator de ambigüidade. Ali onde se previu uma sala eventualmente se organiza um outro aposento; o quarto talvez se transforme em um espaço para práticas religiosas, um escritório, uma "sala da bagunça das crianças", dentre outras tantas formas possíveis de habitar o lugar. De fato, esses novos sentidos dependem da construção que precede o habitar do domicílio. Contudo, o sentido dado pelo morador não é apenas estruturado pelo projeto arquitetônico, mas também estruturante daquele espaço (JOSGRILBERG, 2005, p. 24).

Em Bodocongó, a população subverte os usos oficiais da cidade fenômeno que sempre irá ocorrer, por mais que se planejem e implementem políticas sociais de lazer - de modo que defendemos, antes de qualquer coisa, uma intervenção urbana que deixe a cidade mais limpa e segura, de forma a dar condições dos seus moradores a vivenciarem sem maiores riscos.

6 Mesmo que, concordando com alguns dos seus críticos, tenhamos que entender que essas táticas, muitas vezes, venham a utilizar o sistema, sem necessariamente confrontá-lo. 


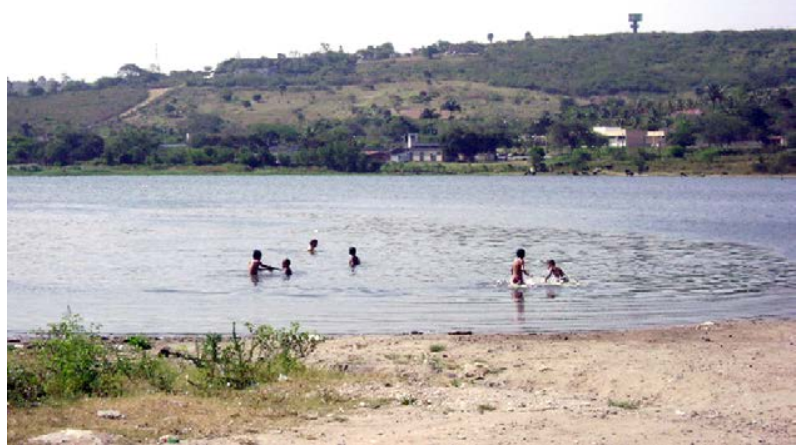

Imagem 02: Açude de Bodocongó: o lúdico convivendo com a tristeza da poluição

Fonte: Arquivos do GCEM

No açude, já não vemos tantos barquinhos compondo a paisagem urbana, mas a alegria da experiência lúdica permanece no local, mesmo em meio à poluição de suas águas, podendo ser vista nos rostos das crianças que brincam por lá, dividindo o espaço com a lavagem de carros e de animais, entre outras práticas dos moradores, que tiram o seu sustento do açude.

Outro local do bairro, onde as crianças gostam de brincar, é o canal que corta a cidade, transportando lixo e água das chuvas. Mesmo nestes locais mais inóspitos, encontramos a alegria da experiência lúdica, coexistindo com a falta de uma estrutura urbana adequada, o que faz com que as crianças do bairro apresentem diversos problemas de saúde, como micoses e verminoses acentuadas.

Entre as inúmeras idas a campo, a fim de compreendermos melhor o cotidiano do bairro, pudemos observar uma movimentação em particular, de quatro crianças no referido canal. Três delas se encontravam na parte interna, ou seja, dentro do canal, enquanto a outra apenas as observava do lado de fora. Indagamos a esta o que estava acontecendo e ela nos respondeu que havia um cachorrinho preso dentro de um buraco na parede do canal, sendo que ele não estava conseguindo sair 
porque estava com medo de cair. Questionada se gostava de brincar no canal, ela respondeu, se afastando-se dos demais, que não, que só quem brincava ali eram eles, os meninos que estavam dentro do canal. Justificando-se, disse que era porque ali era sujo, podia-se pegar doenças.

Percebemos logo as diferenças não só de comportamento, entre aqueles que brincavam e o que apenas assistia. Trajado de farda escolar, enquanto os outros estavam "mauvestidos", ele parecia um pouco triste por não participar do "resgate", enquanto os demais se divertiam bastante com a história do cachorro, mesmo expostos a uma situação na qual poderiam contrair alguma doença. Sabemos que todas elas residiam no mesmo bairro, o que revela as diferenças existentes entre os moradores de uma mesma localidade, parte de um processo sociocultural visível em toda parte, mesmo em se tratando de um bairro periférico como Bodocongó.

Outra brincadeira comum, no bairro de Bodocongó, é a de empinar pipas, que frequentemente enrolam-se nos fios de alta tensão, trazendo riscos para as crianças que as confeccionam. Uma rápida olhada para o céu que cobre o bairro, dá-nos uma ideia da quantidade de pipas que diariamente se perdem no cotidiano lúdico das crianças de Bodocongó.

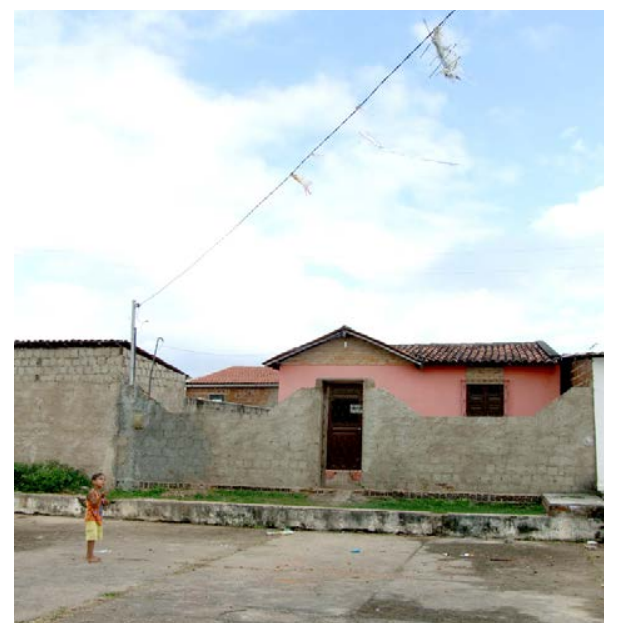

Imagem 03: Pipas: fontes de perigo e alegria em Bodocongó

Fonte: Arquivos do GCE 
Em se tratando do esporte recreativo dos moradores de Bodocongó, pudemos observar a presença constante do futebol, que ora disputando espaço com os carros, nas ruas movimentadas do bairro, ora convivendo com animais de diversos tipos e condições de saúde, insiste em se perpetuar, principalmente nos campos improvisados que ainda existem no local.

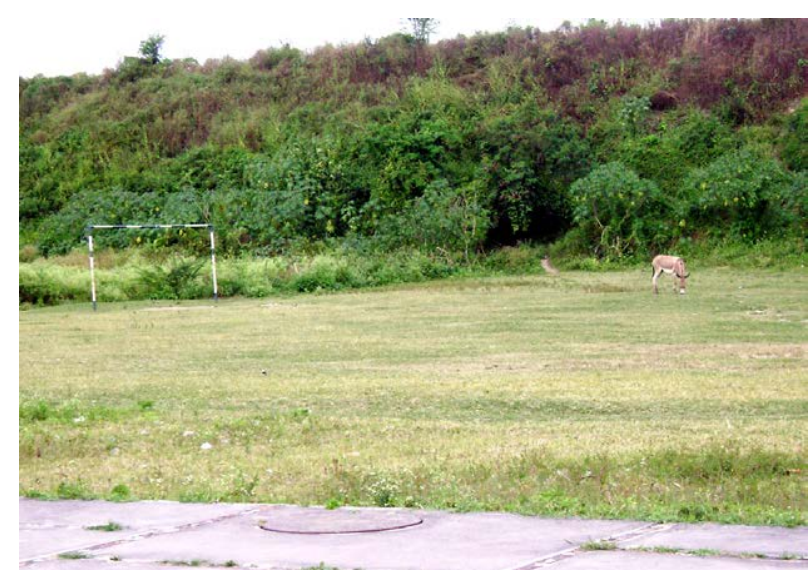

Imagem 04: Campos improvisados: opção de lazer disputada por todas as espécies

Fonte: Arquivos do GCEM

Mas não são apenas esses espaços ou manifestações que têm vez em Bodocongó. Os quadros, a seguir, mostram a riqueza de possibilidades lúdicas encontradas no bairro. Mesmo que possivelmente não retratem, de forma absoluta, a realidade existente em Bodocongó, já que sua grande extensão não nos permitiu uma varredura territorial completa, esses quadros trazem elementos significativos para pensarmos as políticas públicas de esporte recreativo e de lazer do bairro. 0 quadro 1, por exemplo, descreve os principais equipamentos e espaços de lazer identificados em Bodocongó, através dos discursos dos nossos entrevistados ou das nossas idas a campo. 


\begin{tabular}{|c|c|c|c|}
\hline Local & Tipo & Quantidade & Condições de uso \\
\hline UEPB & $\begin{array}{l}\text { Complexo esporti- } \\
\text { vo da UEPB }\end{array}$ & 1 & $\begin{array}{l}\text { Sem problemas } \\
\text { aparentes }\end{array}$ \\
\hline \multirow{3}{*}{$\begin{array}{l}\text { Açude de } \\
\text { Bodocongó }\end{array}$} & Ciclovia & 1 & $\begin{array}{l}\text { Com buracos em } \\
\text { alguns pontos }\end{array}$ \\
\hline & $\begin{array}{l}\text { Pista de cami- } \\
\text { nhada }\end{array}$ & 1 & $\begin{array}{l}\text { Com buracos em } \\
\text { alguns pontos }\end{array}$ \\
\hline & Açude & 1 & Poluído \\
\hline \multirow{5}{*}{$\begin{array}{c}\text { Bairro de } \\
\text { Bodocongó }\end{array}$} & Ruas & - & Trânsito de leve a intenso \\
\hline & Esquinas & - & $\begin{array}{l}\text { Sem problemas } \\
\text { aparentes }\end{array}$ \\
\hline & $\begin{array}{l}\text { Campos improvi- } \\
\text { sados }\end{array}$ & - & $\begin{array}{l}\text { Geralmente com mato e } \\
\text { animais presentes }\end{array}$ \\
\hline & $\begin{array}{l}\text { Antigo terreno do } \\
\text { matadouro }\end{array}$ & 1 & Não observado \\
\hline & Canal & 1 & Poluído \\
\hline $\begin{array}{c}\text { SAB } \\
\text { Bodocongó }\end{array}$ & Quadra & 1 & $\begin{array}{l}\text { Sem iluminação e com } \\
\text { problemas no piso }\end{array}$ \\
\hline \multirow{5}{*}{$\begin{array}{l}\text { Escola Padre } \\
\text { Antonino }\end{array}$} & Pátio & 1 & $\begin{array}{l}\text { Sem problemas } \\
\text { aparentes }\end{array}$ \\
\hline & Espaços livres & - & $\begin{array}{l}\text { Sem problemas } \\
\text { aparentes }\end{array}$ \\
\hline & Quadra & 1 & $\begin{array}{l}\text { Desnivelada, com } \\
\text { quinas à mostra }\end{array}$ \\
\hline & Sala de leitura & 1 & $\begin{array}{c}\text { Sem problemas } \\
\text { aparentes }\end{array}$ \\
\hline & $\begin{array}{c}\text { Espaço atrás da } \\
\text { escola }\end{array}$ & 1 & Não observado \\
\hline
\end{tabular}

Quadro 1 - Espaços e equipamentos para o esporte recreativo e o lazer, existentes no bairro de Bodocongó 
Podemos observar através deste quadro, a existência de espaços e equipamentos planejados para a prática do esporte recreativo e do lazer em Bodocongó, mesmo que em alguns casos, não estejam em boas condições de utilização. 0 maior problema desses espaços e equipamentos, porém, é que eles não se encontram, em sua maioria, disponíveis à população do bairro, já que possuem regras específicas de uso, como aqueles localizados nas escolas públicas.

É o caso da Escola Municipal de Ensino Fundamental Padre Antonino, que através da instalação de segurança eletrônica em seu prédio, fez com que a possibilidade de utilização da mesma nos finais de semana acabasse, já que não havia mais seguranças na escola, que pudessem desligar o alarme para a entrada da comunidade.

Segundo Stucchi (1997), todo equipamento de lazer deve estar situado, de alguma maneira, próximo aos setores residenciais, para que determinada população usufrua de suas instalações. Muito embora, percebemos em Bodocongó, a falta de espaços e equipamentos específicos, adequados e acessíveis para a utilização da comunidade.

De acordo com os nossos dados, a SAB local é um dos principais espaços de lazer existentes no bairro. Sem praça pública que possa ser utilizada como um espaço seguro e agradável para o convívio social, os adultos de Bodocongó costumam se deslocar para bairros vizinhos, como o Centenário, para vivenciarem o esporte recreativo e o lazer.

Segundo visto em nossa pesquisa, uma das únicas práticas de lazer existentes para a comunidade adulta atualmente, é o jogo de dominó nas esquinas, além da caminhada na pista ao lado do açude e o futebol no terreno do antigo matadouro. É importante reforçar a necessidade de que os espaços e equipamentos existentes estejam sempre em manutenção, ou seja, em bom estado de conservação, para o bom aproveitamento de quem os utiliza, pois caso isso não ocorra, eles não serão mais utilizados ou poderão trazer prejuízos à população. 


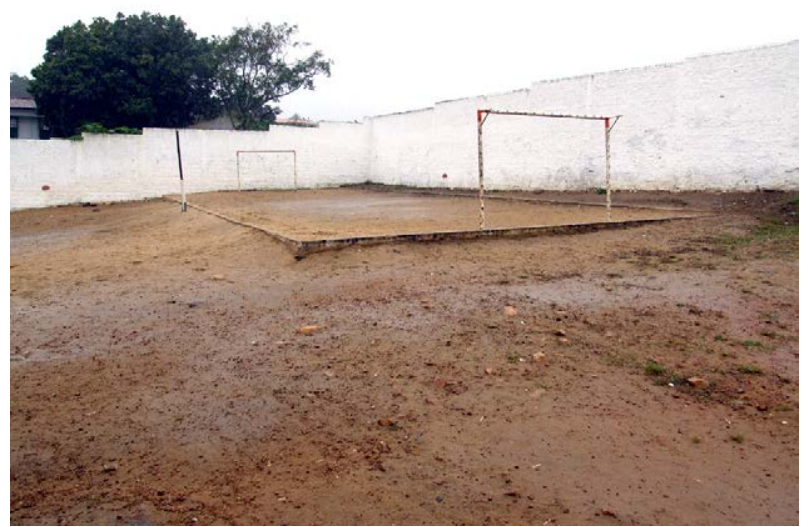

Imagem 05: Quadra da escola: regras específicas e má conservação

Fonte: Arquivos do GCEM

Os eventos, realizados no bairro, revelam uma série de manifestações culturais existentes em Bodocongó, como podemos observar no quadro a seguir, que precisam de uma maior atenção do poder público, no sentido de serem preservadas, já que muitas vezes, carregam consigo a memória e a identidade cultural do bairro. 


\begin{tabular}{|c|c|c|}
\hline $\begin{array}{c}\text { Manifestações culturais } \\
\text { e eventos }\end{array}$ & $\begin{array}{l}\text { Formas de } \\
\text { vivência }\end{array}$ & Temporalidade \\
\hline \multirow{3}{*}{ Futebol } & $\begin{array}{l}\text { Jogos recreativos dos } \\
\text { jovens }\end{array}$ & Diariamente \\
\hline & $\begin{array}{l}\text { Partidas entre os times } \\
\text { dos adultos }\end{array}$ & Finais de semana \\
\hline & Aulas & Semanalmente \\
\hline $\begin{array}{l}\text { Dia das mães, dos pais, } \\
\text { dos avós, dos estudantes } \\
\text { e da criança }\end{array}$ & Festividades & Uma vez por ano \\
\hline $\begin{array}{l}\text { Mostras culturais } \\
\text { e gincanas }\end{array}$ & Festividades & Eventualmente \\
\hline $\begin{array}{l}\text { Pega-varetas; dominó; } \\
\text { damas e xadrez }\end{array}$ & Brincadeiras & Diariamente \\
\hline $\begin{array}{l}\text { Pipa; bila; baleada; pega-pega } \\
\text { e polícia e ladrão }\end{array}$ & Brincadeiras & Diariamente \\
\hline Quadrilhas juninas & Ensaios & $\begin{array}{l}\text { Primeiro semestre do } \\
\text { ano }\end{array}$ \\
\hline \multirow{3}{*}{ Capoeira } & Aulas & Período escolar \\
\hline & Treinos & Semanalmente \\
\hline & Exercícios & Diariamente \\
\hline Bingo & Festividade & Eventualmente \\
\hline Serestas e "louvorsões" & Festividades & Eventualmente \\
\hline Festa de São João & Festividade & Uma vez por ano \\
\hline Aniversários e festas de casamento & Festividades & Eventualmente \\
\hline Bandas & Ensaios & Semanalmente \\
\hline Dança & Vivência & Semanalmente \\
\hline Atividade Física & Vivência & Diariamente \\
\hline Corrida Volta do Bodocongó & Competição & Anualmente \\
\hline $\begin{array}{l}\text { Dança, basquetebol, futsal, voleibol, } \\
\text { natação, judô, handebol, tae kwon } \\
\text { do e ginástica de academia }\end{array}$ & Aulas & Semanalmente \\
\hline
\end{tabular}

Quadro 2 - Manifestações culturais e eventos existentes no bairro de Bodocongó 
Um evento que gostaríamos de destacar no momento, pelo fato de unir educação, saúde e lazer em uma mesma iniciativa, é a corrida "Volta do Bodocongó" que, em 2009, chegou a seu terceiro ano consecutivo. Promovida pela UEPB em parceria com a SAB do bairro, este evento teve o intuito de conscientizar a população sobre a importância da preservação e revitalização do açude.

A corrida contou com o apoio da população de Bodocongó, que durante o evento, recebeu quinhentas mudas de diversas árvores, originárias da escola agrícola da UEPB. Ao final do evento, houve comemoração com festa dançante às margens do açude, animada por um conjunto musical do próprio bairro.

Assim como os espaços apropriados pela população do bairro de Bodocongó, em sua experiência lúdica do lazer, não se limitam aos equipamentos construídos para este fim, as manifestações culturais e os eventos vivenciados no bairro, na maioria das vezes, não fazem parte do calendário oficial de festividades da cidade.

Consideramos importante então, que numa perspectiva intersetorial, o poder público estabeleça políticas culturais capazes de reconhecerem em Bodocongó, eventos e manifestações que traduzem a memória e a identidade cultural de sua população, de forma que elas não desapareçam do cotidiano lúdico do bairro.

\section{Considerações finais}

De acordo com o que apresentamos ao longo deste texto, podemos notar a fragilidade dos espaços e equipamentos específicos de lazer existentes no bairro de Bodocongó, quando focalizamos especificamente suas condições de uso, o que reforça a necessidade de políticas públicas que realmente efetivem o direito ao lazer e não apenas ofereçam estratégias de sobrevivência à população.

Muito embora tenhamos escrito em lei, que todo cidadão tem direito ao lazer de forma digna, o que vemos por lá, é a apropriação corporal dos espaços urbanos, acontecendo em muitos casos, em condi- 
ções ambientais precárias. Fato este que não impede a emergência do lúdico em todos os cantos do bairro, mesmo naqueles mais humildes, como é o caso da "Vila dos Teimosos".

Até porque, como pudemos observar, a experiência lúdica não depende exclusivamente do aporte financeiro que se tem, sendo encontrada, em Bodocongó, no futebol que se joga no meio da rua ou no jogo de dominó das esquinas, entre outras manifestações culturais encontradas.

Como os espaços urbanos vêm se tornando objetos de decoração das grandes cidades, não sendo projetados para serem apropriados corporalmente, como podemos ver até mesmo em Bodocongó, através do "girador"7 que leva a população ao bairro, os moradores veem-se obrigados a se adequar a uma cidade mal planejada, e ainda, a se submeter às diversas formas de violência contidas nela.

Retomando a questão das políticas intersetoriais de lazer, especificamente na interface do lúdico com o desenvolvimento urbano, alertamos para a necessidade de um planejamento que considere o vivido da população, ou seja, que parta e termine na apropriação corporal do espaço urbano, tendo em vista as resistências efetuadas no cotidiano da população.

Planejamento este, que não se limite à construção de cidades "cenográficas" ou mesmo "esportivizadas", mas que, acima de tudo, invista na integridade de seus habitantes, para que eles possam vivenciar o espaço urbano sem maiores riscos e continuar cantando, assim como em Bodocongó, como foram felizes por lá.

\section{Referências}

BRITO, F. D.; JACQUES, P. B. Cenografias e corpografias urbanas: um diálogo sobre as relações entre corpo e cidade. CADERNOS PPG-AU/ FAUFBA, Salvador, v.7, 2008. Edição Especial.

7 Elemento organizador da malha viária, comum na cidade de Campina Grande, que cercado por trânsito intenso, apresenta-se pouco acessível à presença da população. 
CARVAlHO, A. P.; MORAES NETO, J. M.; LIMA, V. L. A.; et al. Aspectos qualitativos da água do açude de Bodocongó em Campina Grande - PB. Engenharia Ambiental, v. 5, n. 2, 2008.

CERTEAU, M. A invenção do cotidiano: artes de fazer. Petrópolis: Vozes, 1998.

CHEMIN, B. F. Políticas públicas de lazer: o papel dos municípios na sua implementação. Curitiba: Juruá, 2007.

IBGE - Instituto Brasileiro de Geografia e Estatística.Censos Demográficos 1991/2000. 2002.

JACQUES, P. B. (Org.). Apologia da deriva: escritos situacionistas sobre a cidade. Rio de Janeiro: Casa da palavra, 2003.

JOSGRILBERG, F. B. Cotidiano e invenção: os espaços de Michel de Certeau. São Paulo: Escrituras Editora, 2005.

MARCELLINO, N. C. Estudos do lazer: uma introdução. Campinas: Autores Associados, 2002.

PINTO, L. M. S. M. Estado e sociedade na construção de inovações nas políticas públicas sociais de lazer no Brasil. In: MARCELLINO, N. C. (Org.). Políticas públicas de lazer. Campinas: Alínea, 2008.

SILVA, R. H. A.; FONSECA, C. G. Cartografias urbanas: lugares, espaços e fluxos comunicativos. In: Encontro da Compós, 16, 2007, Curitiba. Anais... Curitiba, 2007.

SOARES, C. L. Cultura de movimento. In: SESC. Corpo, prazer e movimento. São Paulo: SESC-SP, 2007.

SOUSA, L. G. Economia, política e sociedade. 2006. Disponível em: <http://www.eumed.net>. Acesso em: 14 abr 2009. 
STUCCHI, S. Espaços e equipamentos de recreação e lazer. In: BRUHNS, H. T. (Org.). Introdução aos estudos do lazer. Campinas: Editora da Unicamp, 1997.

SUASSUNA, D.; ALMEIDA, A. J. M.; FREIRE, J. O.; ROQUETE; P. C. O Ministério do Esporte e a definição de políticas para o esporte e lazer. In: SUASSUNA, D.; AZEVEDO, A. A. (Orgs.). Política e lazer: interfaces e perspectivas. Brasília: Thesaurus, 2007.

UNIÃO CAMPINENSE DAS EQUIPES SOCIAIS. Estatuto. Campina Grande, 2006. Disponível em: <http://www.ucescg.com.br/estatutos. html>. Acesso em: 14 abr. 2009. 



\title{
Bairro José Pinheiro: uma história de lazer e cultura popular limitada pela violência
}

\author{
Priscilla Pinto Costa da Silva \\ Cheng Hsin Nery Chao
}

\section{Introdução}

O bairro José Pinheiro, localiza-se na Zona Leste da cidade de Campina Grande/PB. Sua população atinge 17.048 habitantes, segundo dados do Instituto Brasileiro de Geografia e Estatística - IBGE (2000). Considerado um dos bairros mais antigos e populares da cidade, caracteriza-se por ter o segundo maior comércio do município, além de várias empresas calçadistas, o que oportuniza empregos para a própria população do bairro. A renda per capita é de aproximadamente R\$ 385,55 de acordo com o Censo Demográfico do IBGE (2000).

Lembranças do bairro José Pinheiro são trazidas através de músicas como Saudades de Campina Grande e Forró em Campina, compostas por Rosil Cavalcanti e Jackson do Pandeiro, respectivamente. Fatos históricos do bairro, também, podem ser recordados por meio do filme Os Balões de 74, dirigido por Luciano Mariz, que trata de uma tragédia deste bairro, onde um cilindro de gás explode em um parque de diversão instalado no bairro, no dia de Natal em 1974, matando 8 pessoas e deixando vários feridos.

Para o desenvolvimento do estudo, contamos com apoio dos representantes da Sociedade Amigos do Bairro do José Pinheiro, de alguns 
moradores, de coordenadores de programas sociais ${ }^{1}$, de autores e diretores de estudos que abordam o bairro, além do referencial teórico encontrado nas fontes de informações visitadas ${ }^{2}$.

Além das pesquisas supracitadas, utilizou-se ainda o Suplemento de Esporte da Pesquisa de Informações Básicas Municipais - MUNIC 2003, no qual foi um material de suma importância para traçar o perfil de alguns aspectos referentes ao esporte, comparando-os com a atualidade. O MUNIC 2003, juntamente com o IBGE em parceria com o Ministério do Esporte, investigou diversos temas relacionados à gestão do esporte nos municípios brasileiros, mas necessitava de complementações que tentamos desenvolver através desta pesquisa.

\section{Espaços e equipamentos como possibilidade de interfaces entre educação, lazer e saúde}

A SAB do José Pinheiro "procura defender... os mais humildes no bairro e nas suas dificuldades", segundo declara o presidente. Para ele, esta organização é um instrumento de reivindicação, assim, a sociedade pode participar dos planejamentos e construções de benefícios para o bairro. Seguindo as ideias de Pinto (1998), os desejos de avanço e democratização aos trabalhos do Estado em busca do saber, da saúde, das ações socioculturais para a construção, e condições básicas de vida cotidianas, levam as novas expectativas dos sujeitos mais marginalizados.

Uma das principais reivindicações atendidas no bairro do José Pinheiro, foi a revitalização ${ }^{3}$ do Complexo Desportivo Plínio Lemos que, segundo os moradores, encontrava-se em condições precárias e estava sendo utilizada como um dos pontos de tráfico de drogas do bairro. Segundo o MUNIC 2003, na cidade de Campina Grande, não havia ações, projetos e programas no Esporte e Lazer para comunidades carentes.

1 Programa Pró-Jovem, Diretor da Vila Olímpica Plínio Lemos - escolhidos devido à importância dos mesmos para a formação e integração social dos jovens do bairro.

2 Livros, teses, dissertações, artigos nacionais e internacionais, revistas magazines, jornais da cidade, filmes, sites da internet e blogs.

3 Anteriormente era um pequeno estádio de futebol, que foi totalmente reestruturado. 
Com este novo espaço, há possibilidade de promover diversas atividades visando benefícios à comunidade carente do bairro.

O Complexo Desportivo Plínio Lemos, reinaugurado em março de 2008, proporciona diversas atividades e abrange a comunidade, seja criança, jovem, adulto ou idoso, como enfatiza a entrevista com o coordenador da instituição. 0 complexo esportivo oferece uma estrutura inovadora para a região, com o Museu do Futebol, Coordenação do Pró-Jovem, Unidade do Programa de Saúde da Família; em seus equipamentos há um campo de futebol, uma pista de atletismo, quadras de vôlei e futebol de areia, um ginásio poliesportivo, uma piscina coberta para uso terapêutico e atividades lúdicas, sala para artes marciais e playground. Ainda há uma estrutura de uma pista para atividades radicais, como o skate e patins in line. Este tipo de prática corporal é bastante popular entre os adolescentes do bairro do José Pinheiro, e as características mais fortes destas práticas são os sentimentos de risco e a emoção, embora pareçam ser paradoxos, estes aspectos estão interligados aos praticantes.

Para manter o funcionamento do Complexo Desportivo Plínio Lemos, além da prefeitura, que é responsável pela manutenção da estrutura física e o pagamento dos funcionários, o espaço ainda conta com o apoio do Instituto Alpargatas que financia o material desportivo e uniformes. As ações sociais desenvolvidas, neste espaço, visam a melhoria da qualidade de vida da sociedade, contando com atividades como iniciação à natação, futsal, dança, aeróbica, e outras, além de promover torneios esportivos, eventos em datas comemorativas, festa mix ${ }^{4}$, oficinas de teatro.

4 Festas para a juventude com Dj's e Street Dance. 


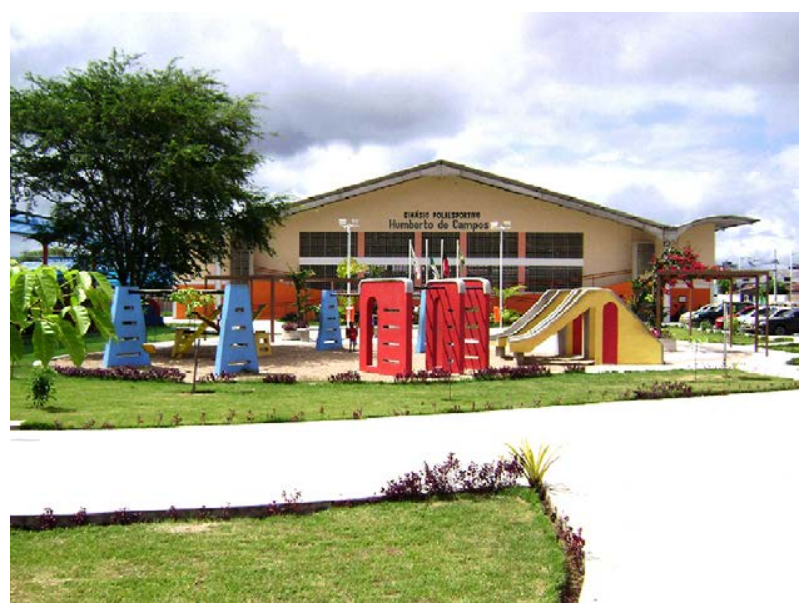

Imagem 01: Playground e Ginásio Poliesportivo Fonte: Arquivo GCEM

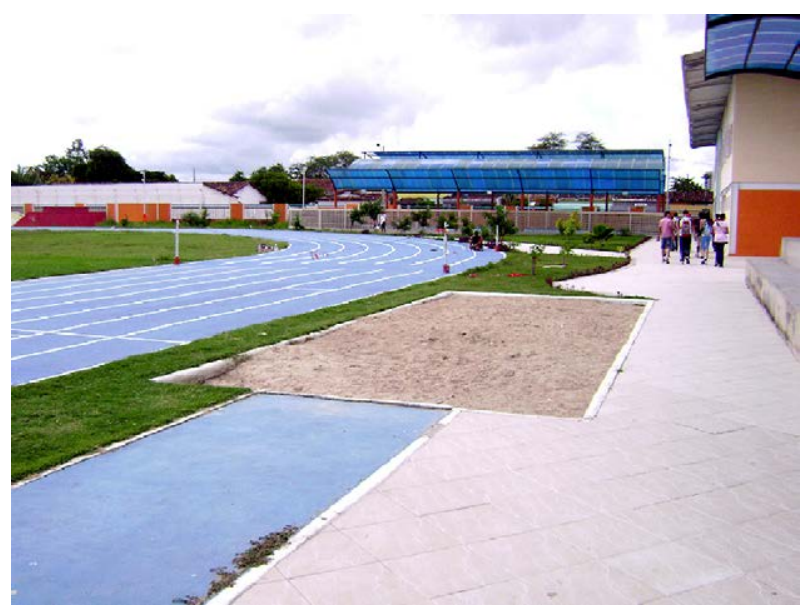

Imagem 02: Pista de atletismo, caixa de areia e piscina coberta ao fundo

Fonte: Arquivo GCEM 
Há projetos desenvolvidos em parceria com outras entidades, como o Projeto Futebol Cidadão que realiza aulas periodicamente na instituição. Segundo o diretor, o futebol é um esporte tão forte, na cultura do bairro, que acaba sendo a modalidade mais procurada.

O Programa Esporte e Lazer da Cidade (PELC) ${ }^{5}$, incluía uma unidade nas instalações do Complexo Desportivo Plínio Lemos. Segundo Relatório do SESI (2009), promovia ações voltadas à saúde (nutrição, odontologia) e atividades físico-desportivas. Funcionou no período de março/2008 a março/2009, quando teve suas atividades encerradas devido ao fim do convênio com o Ministério do Esporte.

No Complexo Desportivo Plínio Lemos funciona programas para as diferentes faixas estárias, promovendo a socialização e conhecimentos que permitem oferecer o esporte e o lazer tratados como direito de todo cidadão. Na entrevista, o coordenador do Complexo Desportivo Plínio Lemos aponta que o objetivo central "é tirar crianças da rua e "jogar" aqui dentro. A gente não tem objetivo de formar atletas, e sim formar cidadãos, nosso objetivo aqui é de iniciação desportiva. Se o cara se destaca, alguém encaminha pra outro setor". São cerca de 12 mil pessoas beneficiadas por estas ações comunitárias.

O esporte e o lazer possibilitam promover transformações sociais para o cidadão por meio de atividades lúdicas, como aponta Costa (1999, p. 114): “o que é fundamental na atividade lúdica parece ser o trabalho de transformação simbólica a que se submete o ator, elaborando a fantasia na experiência corporal lúdica", assim percebe-se o imaginário proporcionado pelas vivências no esporte e lazer no sentido de mudança social do indivíduo. Caillois (1990), vê o jogador, neste caso o sujeito participante, adotar as características de um ator na vivência lúdica.

As políticas públicas que promovem o esporte e o lazer incentivam, através deste sentido, a formação consciente do cidadão. Nesta perspectiva, o bairro José Pinheiro, por meio destes objetivos, pode diminuir o índice de violência, visto que o bairro é considerado um dos mais violentos da cidade, fator de preocupação para toda a sociedade.

5 Promovido pela Secretaria Nacional de Desenvolvimento de Esporte e de Lazer (SNDEL) do Ministério do Esporte, em parceria com SESI-PB nas cidades de Campina Grande e João Pessoa. 
Acompanhando este pensar, Elias (1993) preocupou-se em estudar o controle da violência, visto que esta problemática é um aspecto do processo civilizador. $O$ autor relaciona a civilização e a violência como um processo de longa duração, ou seja, o exemplo de análise sociológica reflete na interdisciplinaridade dos processos sociais, baseado na experiência de fenômenos sociais, situando-se em fatos históricos.

Acredita-se que por meio das políticas públicas de esporte e lazer, seja possível colaborar para reverter este quadro de violência do atual momento do bairro José Pinheiro, reforçado pelos moradores durante a pesquisa de campo. Espera-se que estas ações possam agir de forma transformadora nos indivíduos participantes e atuantes destas políticas.

Neste sentido, é importante mencionar os estudos de Gonçalves (2003, p. 53), em que ressalta os aspectos da promoção do esporte e lazer e a violência em comunidades, nos quais frisa

\begin{abstract}
as tentativas de desenvolvimento de um 'etos civilizador' que afaste o jovem dessa realidade hostil, permitindo a implementação de práticas sociais que propiciem uma sociabilidade afirmativa e ampliem as possibilidades de participação desse jovem na sociedade, contribuem para a construção de uma cidadania plena, garantindo assim a saúde da coletividade.
\end{abstract}

A violência pode ser um fator que interfere em outros aspectos como, por exemplo, a promoção da atividade física e saúde, em que os sujeitos sentem-se impedidos em explorar os espaços e equipamentos públicos pela falta de segurança que comumente encontra-se nestes ambientes. Segundo o presidente da SAB, há quadrilhas de traficantes de drogas e marginais que utilizam as praças e quadras e não permitem o livre acesso dos moradores.

Assim, é necessário ressaltar, neste momento, que as políticas públicas de esporte e lazer são insuficientes por si só de transformar completamente o indivíduo, no entanto, são práticas de iniciação à transformação social do cidadão a partir de projetos de ação social comunitária. É necessário que outros setores como educação, saúde 
se integrem, criem novas possibilidades que consigam integrar esses indivíduos tirando-os da marginalidade.

Além de projetos voltados ao esporte e lazer, o Complexo Desportivo Plínio Lemos ainda oferece, em seus estabelecimentos, centro de capacitação profissional para a população, qualificando sujeitos para possibilitar o acesso às oportunidades e iniciarem uma profissão e/ ou serem inseridos no mercado de trabalho. Um desses projetos que merece destaque é o Pró-Jovem Adolescente, um projeto a nível nacional, promovido pela prefeitura em parceria com o Governo Federal, que atende aproximadamente 3 mil adolescentes na cidade de Campina Grande, distribuídos em vários bairros, adolescentes entre 15 a 17 anos de idade, em que visa oportunizar aos adolescentes qualificar-se para o primeiro emprego, os cursos oferecidos são: computação, técnicas de vendas, garçom..., eletricista, hotelaria, temos vários cursos e oficinas também, relata um dos funcionários do programa, em entrevista. O Pró-Jovem funciona há um ano substituindo o Agente Jovem, que era o programa antigo... que só tinha 350 adolescentes. Esse programa também faz articulações com a SAB e o Clube de Mães da cidade em determinados eventos promovidos.

Estes adolescentes têm oportunidade de estagiar, para adquirirem experiências, para inserir ao campo de trabalho, há parcerias com várias instituições que abrem espaço para o estágio, com acompanhamento supervisionado, além disso, há o acompanhamento com a família, realizado pelo Centro de Referência de Assistência Social - CRAS, assim o Pró-Jovem está inserido no CRAS para promover essa ligação do adolescente em uma formação profissional e em uma assistência familiar por meio de órgãos públicos, contando com o apoio de 54 orientadores sociais.

Outro fator interessante a ser destacado, neste estudo, são as instalações das Unidades Básicas do Programa de Saúde da Família (UBSF), que funciona também no Complexo Desportivo Plínio Lemos, o qual oferece serviços médicos, enfermagem, odontológicos, imunização atingindo os segmentos mais vulneráveis da sociedade, promovendo, assim, a saúde e melhor qualidade de vida aos sujeitos do bairro José Pinheiro. A promoção da saúde, por meio das políticas públicas, é uma estratégia de orientação e assistência à sociedade para suprir suas ca- 
rências, atendendo as famílias em um contexto social, estabelecendo vínculos de democratização, contribuindo e beneficiando a saúde. E ainda há a base de polícia comunitária e uma cozinha popular.

O Bairro José Pinheiro dispõe ainda de uma farmácia popular que oferece medicamentos com preços mais acessíveis à comunidade e a atenção de um farmacêutico, o qual ajuda aos usuários esclarecendo dúvidas entre outros atendimentos farmacêuticos.

No entanto, a sociedade ainda recorre a SAB quanto às questões da saúde e reivindica um posto de saúde, com ambulância, como afirma o presidente da SAB do José Pinheiro, embora os pedidos já solicitados, esta reivindicação ainda não foi atendida. Observa-se que um posto de saúde para uma comunidade de um bairro bastante populoso, é de grande importância para atender as necessidades dos cidadãos que precisam de cuidados médicos mais urgentes.

Recentemente a comunidade do bairro José Pinheiro foi beneficiada com o espaço para abrigar o Clube de Mães, visto que o clube existe há 44 anos, e não tinha um local próprio. Em parceria com o Governo do Estado, as reivindicações da população foram atendidas e agora o Clube de Mães tem sua própria sede, que disponibiliza salas para realização de atividades e cursos que favorecerão as mães do bairro. 0 Clube de Mães do José Pinheiro dispõe de 10 salas, onde são desenvolvidos cursos de capacitação como o de costureira, cabeleireira, além de atividades com o grupo da terceira idade, e ações educacionais com os filhos das mães associadas. 0 bairro José Pinheiro ganha mais um espaço, para promover outras ações de cidadania que beneficiarão diretamente os participantes.

Outras reivindicações da comunidade do bairro José Pinheiro destacadas pelo presidente "são uma agência de Correios...o povo queria um museu do futebol paraibano em Campina Grande, no José Pinheiro", está montado no Complexo Desportivo Plínio Lemos ${ }^{6}$ - o prazer pelo futebol é uma forte característica dos moradores. Outra solicitação da comunidade que o presidente da SAB cita é que "nós precisamos de um velório, pois quando morre gente pobre, aí vem aqui vai pedir ajuda a

6 Percebe-se que o Complexo Desportivo Plínio Lemos, conhecido como Vila Olímpica Plínio Lemos, concentra lazer, saúde, educação e cultura, sendo um modelo de instituição diferenciado e de grande influência positiva para a sociedade. 
mim pra botar... uma pessoa aqui que morreu". A comunidade reivindica "um velório em José Pinheiro para servir ao povo, porque a maioria, quando morre, fica a metade dentro de casa e a outra metade do lado de fora". Existe até um local nas proximidades da SAB que o presidente sugere a construção do velório ao declarar que "aqui atrás temos um pedacinho de campo que dá pra fazer".

As praças, as ruas e a quadra são apontadas pelos moradores como necessitadas de manutenção e segurança, pois crianças e jovens brincam, nestes espaços, que se encontram depredados. Na maior praça do bairro, Praça Joana D’Arc, encontra-se um playground, em que as crianças brincam no escorregador, pois os outros equipamentos, como a gangorra e os balanços estão quebrados por falta de manutenção.

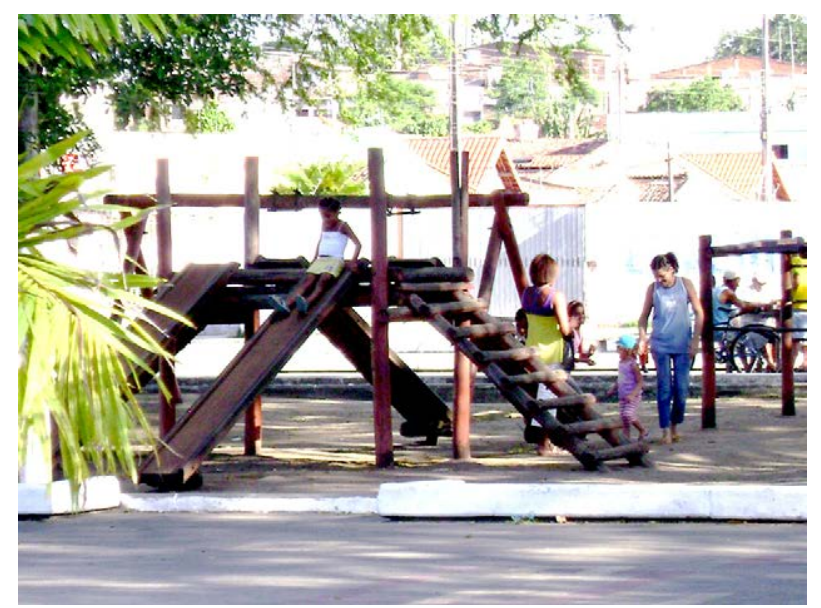

Imagem 03: Praça Joana D’Arc - playgroud Fonte: Arquivo GCEM

As praças são equipamento de grande importância para uma comunidade, pois parafraseando Robba e Macedo (2003, p. 17) as "praças são espaços livres públicos urbanos destinados ao lazer e ao convívio da população, acessíveis aos cidadãos e livres de veículos". Percebe-se que as praças são equipamentos públicos que caracterizam como espaço de lazer e sociabilização. 


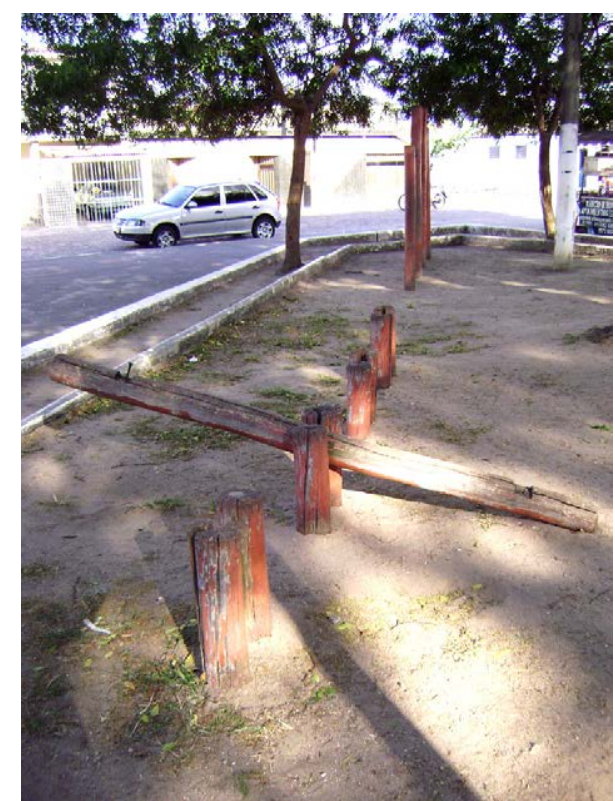

Imagem 04: Praça Joana D’Arc - playground, brinquedos depredados.

Fonte: Arquivo GCEM

No bairro José Pinheiro, é possível observar, nas praças e nas ruas, crianças brincando de pega-pega, empinando pipa, jogando bola ou até mesmo conversando. Para Zacarias (1999) a rua é um cenário para os mais diversos acontecimentos, é na rua que se compartilham aprendizagens e interage entre si, um intercâmbio de informações e conhecimentos de brincadeiras lúdicas.

Segundo Chemin (2007), o poder público não pode omitir os aspectos que abrangem a promoção do lazer, deve proporcionar acesso à cultura e ao entretenimento. Embora estes equipamentos estejam em condições precárias, crianças e adolescentes dividem estes espaços para o desenvolvimento de brincadeiras com o lixo espalhado pelo local, o que torna um risco à saúde da comunidade. 0 lixo é outra reivindicação que a sociedade protesta, para não tornar um agente disseminador de doenças na comunidade. 
Observa-se que algumas reivindicações da comunidade já foram acatadas, no entanto ainda há exigência da comunidade para serem atendidas, requisições para as políticas públicas que precisam de urgência, para um melhor funcionamento harmonioso da cidade.

\section{Educação e lazer na comunidade}

Além de ser um instrumento de reivindicação da comunidade, a SAB do José Pinheiro promove diversas atividades de interesse para a população, promovendo palestras de diversas temáticas, atividades lúdicas, inclusão de pessoas deficientes, reuniões para prevenção ao uso das drogas, para toda a sociedade que se interessa em participar destas promoções. Para a realização destas atividades, a SAB conta com o apoio de vários voluntários da cidade que desenvolvem e organizam sistematicamente ações que objetivam melhorar e promover o conhecimento da sociedade.

Um fato lamentável destacado pelo presidente da SAB foi a extinção de uma escola que funcionava nas instalações da SAB, por motivos de desentendimento político, o presidente declara que:

... ele achou que devia tirar a escola daqui. E lutou, lutou, lutou, e como ele era o secretário do município tirou a escola daqui. Mas nós tínhamos cento e oitenta e cinco alunos, o povo gostava da $S A B$, merendava de primeira grandeza, tinha porque, nós recebíamos o dinheiro da merenda e comprávamos a merenda... agora, inclusive os funcionários eram loucos para trabalhar comigo, porque aqui nós tínhamos seis professores, quatro serventes, oito vigilantes, era todo...todo mundo te envaidecia e eu me sentia feliz.

Alunos e funcionários foram atingidos com a desativação da 'Escola Municipal da SAB do José Pinheiro', embora a organização da escola ainda tenha reivindicado a volta do funcionamento, ela não foi atendida, como explica o presidente da SAB "lutamos... e não foi possível a gente reabrir a escola". Apesar de ser procurado posteriormente para reativar a escola, o presidente informou que não desejava mais a re- 
vitalização, como confessa em suas palavras “... quero mais não, quero mais não, já perde, a gente perde aquele estímulo".

O bairro José Pinheiro conta atualmente com o funcionamento de quatro escolas municipais que oferecem educação escolar do pré ao fundamental II, distribuídas pelo bairro, que promovem a educação de crianças, jovens e adultos, o que colabora para a diminuição do índice de analfabetismo do bairro. Algumas escolas encontram-se em situações problemáticas, mesmo assim, estão ativadas, outras precisam apenas de atenção e manutenção em seus equipamentos, além de recursos materiais para dar continuidade as suas atividades.

Compartilhando com o pensamento de Almeida (2003), também entendemos que a escola possa disponibilizar espaços para lazer e para prática de atividades físicas. Estes espaços são importantes para o desenvolvimento educacional, psicomotor, afetivo e social de crianças e jovens no período que se encontram nas escolas, como aponta Almeida (2003) o lazer, na escola, "possibilita acesso a novas linguagens e experiências pedagógicas favorecendo olhares diferenciados em relação ao conhecimento".

A busca pelo lazer da comunidade do bairro José Pinheiro, além da quadra, das praças, ruas ou nas escolas, como foi mencionado, há ainda o comércio do tipo bodegas como opção de lazer, é o que destaca Diniz (2004, p.11) em sua dissertação As bodegas da cidade de Campina Grande: objetos de permanência e transformação do pequeno comércio no bairro de José Pinheiro. Neste estudo, bodega é entendida por "uma pequena unidade familiar comercial, constitui um tipo de comércio muito popular e antigo da região". 


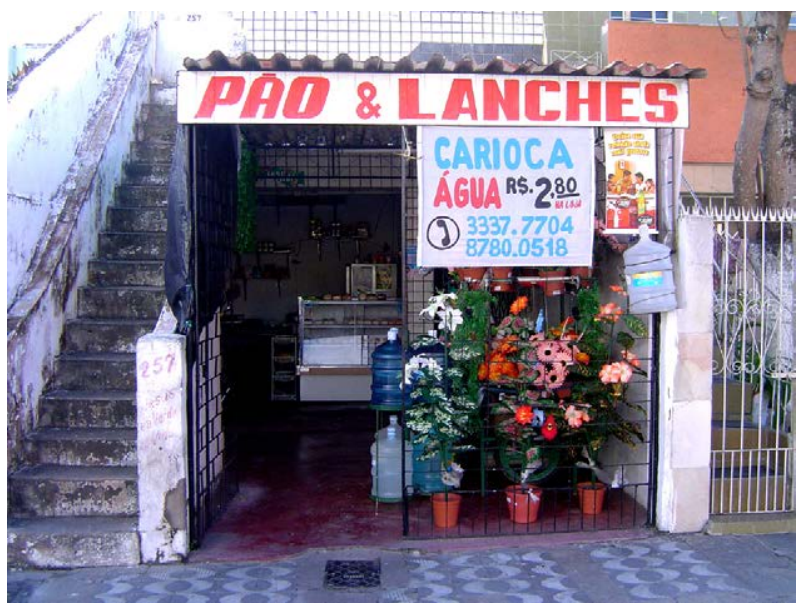

Imagem 05: Bodega do bairro

Fonte: Arquivo GCEM

Segundo Diniz (2004, p. 14), a formação deste tipo de comércio foi fundamental para a formação e desenvolvimento do bairro José Pinheiro, parafraseando o autor "a importância da bodega na vida deste bairro remonta desde as origens do lugar, onde sempre desempenhou uma função social e econômica importante entre os seus moradores, contribuindo, deste modo, na construção do seu espaço".

A função social das bodegas, apresentada pelo autor, é observada na quantidade de pessoas que as frequentam no bairro José Pinheiro, estes sujeitos nem sempre vão para realizar algum tipo de compra, mas para se encontrar com amigos, estes estabelecimentos tornaramse pontos de encontros, proporcionando o convívio entre as pessoas. Concordando com as ideias de Diniz (2004, p. 151), as bodegas "proporcionam um amistoso ambiente de convívio social onde, como de costume, ocorrem com frequência encontros de moradores conhecidos das vizinhanças".

De acordo com os estudos de Diniz (2004), cerca de 44\% das bodegas oferecem em seus estabelecimentos vários tipos de bebidas alcoólicas, em pequenas doses para facilitar a compra pelos consumidores. Esta tradição de venda de bebidas já apresentou uma percentagem 
maior, no entanto, segundo o autor enfatiza, muitos comerciantes estão deixando de vender bebidas, alegando o alto índice de violência, no bairro, provocando assaltos, brigas, assassinatos entre outros aspectos criminais.

Os problemas gerados pela violência, no bairro, têm preocupado a comunidade local e a muitos sujeitos da cidade de Campina Grande, que buscam soluções para abolir esta dificuldade que vem tornando frequente ações contra os moradores. Este é um aspecto existente, no bairro, que precisa ser revertido com urgência, para que, em harmonia, os espaços públicos e privados de lazer, como o exemplo das bodegas retratado por Diniz, possam funcionar e trazer para a população melhor qualidade no sentido do bem-estar na promoção do lazer.

Em visita a algumas bodegas, pôde-se perceber um espaço de convívio onde as próprias lutas da comunidade são discutidas, desta forma, é notória a influência na formação da opinião da comunidade, não deixando apenas para a escola e instituições comunitárias esse caráter formativo.

\section{Manifestações de ontem e manifestações de hoje}

A cultura é uma construção histórica que exerce um papel fundamental no processo de desenvolvimento do fenômeno sociocultural decorrente de valores individuais e sociais. Fazendo menção aos estudos de Santos (2005, p. 50), entende-se cultura como:

[...] dimensão da sociedade que inclui todo o conhecimento num sentido ampliado e todas as maneiras como esse conhecimento é expresso. É uma dimensão dinâmica, criadora, ela mesma em processo, uma dimensão fundamental das sociedades contemporâneas.

A cidade de Campina Grande possui uma pluralidade de manifestações culturais, os eventos que mais se destacam são: O Maior São João do Mundo, Micarande, Festival de Inverno e o Encontro da Nova Consciência. $\mathrm{O}$ bairro José Pinheiro é bastante participativo nas manifesta- 
ções culturais da cidade, é por meio delas que as pessoas expressam-se individualmente ou em grupos explanando seus conhecimentos e valores populares. Segundo Nascimento e Lemos (2006, p. 14), “a cultura popular está centrada na raiz de uma população, cuja nascente está no desejo de expressão a partir de sua bagagem histórica". Desta forma, a população local busca comemorar os festejos culturais com alegria em um sentido de celebrar a cultura popular, resgatando seus traços históricos.

Ainda seguindo os pensamentos das autoras, o bairro José Pinheiro "é apontado como o eixo das batucadas de Campina Grande, sendo possuidor de uma vasta fonte de cultura" (NASCIMENTO; LEMOS 2006, p. 44). No estudo, as autoras expõem a riqueza cultural existente neste bairro, que traz em suas manifestações o pastoril, bumba-meuboi, ala-ursa, tribo de índio, além da quadrilha como foi mencionada pelo presidente da SAB.

O bairro conta com a participação de alguns bumba-meu-boi, no período carnavalesco, que desfilam pelas ruas da cidade, acompanhados por outros participantes que tocam alguns instrumentos musicais e seguidos por cantigas folclóricas. Há ainda uma personagem que chama a atenção da comunidade que é conhecida como a "Veia da Bundona", em que usa vestidos bastante colorido de armação, improvisado com balaio, para facilitar o seu rebolado. Ela sai juntamente com o bumba-meu-boi e tem a função de pedir dinheiro ao público que assiste ao desfile. Ao final, o dinheiro arrecadado é dividido entre os participantes.

A construção do bumba-meu-boi é realizada pela própria comunidade com a participação de crianças, jovens e adultos. Geralmente são utilizados para a fabricação do bumba-meu-boi materiais recicláveis, como o papelão, e cobertos por tecidos estampados, deixando-o bastante colorido. 0 bumba-meu-boi faz a alegria das crianças, as quais não deixam morrer esta tradição regional. A vivência neste tipo de manifestação representa características populares por meio da música, expressões, cores, danças, festejando, assim, as recordações e conhecimentos de uma população. 
Durante o período carnavalesco, ainda conta com a participação de duas escolas de samba no bairro, como afirma o presidente da SAB. Estas escolas de samba desfilam no Carnaval dos que Ficam ${ }^{7}$, que conta com o apoio de um vereador da cidade para a organização da festa (CÂMARA MUNICIPAL DE CAMPINA GRANDE, 2008). Apesar dos poucos recursos financeiros, a população invade a avenida com muita alegria e animação, trazendo o samba-enredo, frevo e a energia do povo campinense. Ainda se apresentam, neste evento, os bumba-meu-boi e ala-ursas que contagiam o povo com suas performances e agitação.

0 pastoril também foi mencionado pelo presidente da $\mathrm{SAB}$, como uma manifestação lembrada pelo povo. Côrtez et. al. (2004) aponta que o pastoril busca homenagear o nascimento de Jesus Cristo, através de uma dança simbólica.

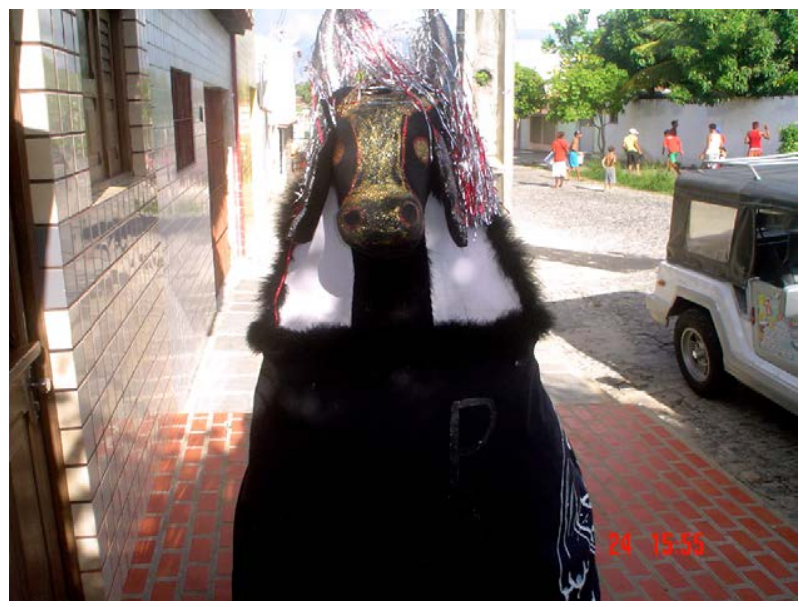

Imagem 06: Apresentação do Boi Pantera no Carnaval dos que Ficam

Fonte: Arquivo GCEM

Outra manifestação cultural presente, no bairro e em toda a cidade, é a quadrilha. Acredita-se que a quadrilha é uma das manifestações populares mais vivenciadas pela população campinense, podendo justifi-

7 Evento realizado anualmente em Campina Grande no período carnavalesco (NASCIMENTO; LEMOS, 2006) cujo nome remete-se àqueles que ficam, na cidade, durante o período, uma vez que, a maioria da população viaja para o litoral. 
car pelo fato de ser vivenciada no mês de junho, o qual comemora-se o São João, e a cidade sedia "O Maior São João do Mundo", festa realizada no Parque do Povo (MENDONÇA et. al., 2008). As quadrilhas do José Pinheiro são organizadas e ensaiadas pelas ruas, praças, quadras, importantes espaços de lazer e palcos que retratam a vivência cultural e arte produzida no bairro.

Os ensaios ocorrem, também, nas casas de alguns integrantes da quadrilha, são meses de preparação, planejamento do figurino, fabricação das vestimentas, uma imensa dedicação que chamam a atenção pelos estilos, podendo ser estilizadas ou tradicionais.

Além do Parque do Povo, as quadrilhas são apresentadas nas ruas dos bairros, praças, em shoppings, nas escolas e outros estabelecimentos públicos ou privados, que disseminam esta tradição. As quadrilhas juninas disputam pela cidade mostrando suas belezas, criatividade, cores, simpatias e coreografias, que através de um campeonato realizado comumente, no Parque do Povo, a comissão julgadora avalia várias categorias propostas pelas quadrilhas dos bairros e até de outras cidades que vêm participar do evento.

0 presidente da SAB ainda contribui para este estudo, declarando que antigamente a SAB do José Pinheiro era mais participativa nas manifestações culturais, promovendo festas populares para a comunidade. No entanto, infelizmente estas promoções foram diminuindo, pois como explica o presidente da SAB

hoje se deixa de se fazer, porque hoje todo mundo anda com uma peixeira, ou um revólver na cintura, hoje o caba com dezessete ano é maior do que eu e pinta e borda, então todo mundo foi acabando com as festas, ficam com medo... mas de primeiro tinha festa... se promovia o São João, se promovia pastoril, se promovia a festa de São José...

Estas festas foram promovidas até por volta de 1980, como ressalta o presidente da SAB "funcionou até 1980, de 80 pra cá as coisas se modificaram..." Ele ainda afirma que a $S A B$ "promovia festa, promovia demais, quadrilha, nós promovemos muita quadrilha, mais o negócio é que nós fomos sentindo que não tinha segurança". 
Retornando aos estudos de Diniz (2004, p. 7), o autor afirma que "no passado, o bairro representava um espaço da cultura popular local, como lugar de festejos". Todavia as celebrações destas festas populares estão sendo atingidas pela violência, trazendo risco, até mesmo de vida, as pessoas que buscam festejar e preservar a cultura popular, fragilizando, desta forma, as vivências das manifestações populares.

Segundo o gestor da SAB, as comemorações no bairro "estão chegando ao fim ou não existem mais. Os motivos que causam essa triste realidade são: a violência no bairro e a falta de políticas públicas". A segurança, nas ruas, é um grande problema social vivenciado nas cidades, e é através das políticas públicas que se reverte esta situação, para a sociedade sentir-se mais segura e as tradições populares não perderem suas características.

As manifestações populares são de suma importância para a sociedade conhecer sua história, resgatando suas tradições, as quais não se podem deixar apagar os traços culturais existentes em cada povo. Os aspectos socioculturais de uma sociedade que, através de anos e até séculos, foram construídos, e culturalmente modificados são descrições de uma cultura contemporânea.

As manifestações culturais são riquezas que devem ser preservadas e vivenciadas pela população. Correlacionando a realidade atual vivenciada pelos moradores do bairro José Pinheiro e a dimensão entre o lazer e as manifestações culturais, percebe-se uma delicada realidade que a comunidade vivencia em consequência da violência que, muitas vezes, é provocada pela própria população do bairro.

\section{Considerações e sugestões}

0 recorte deste estudo focaliza um bairro que se diferencia pela sua história, suas conquistas e, em especial, seu povo. Com fortes características em suas manifestações culturais, que resgatam acontecimentos históricos e são celebrados pelas ruas da cidade. 0 bairro José Pinheiro destaca-se ainda, pelo amplo comércio existente, onde também são pontos de sociabilização desta comunidade. Contudo, existe 
um viés que está colocando em risco tanto a própria população, como a lembrança da cultura popular da região: a violência.

Torna-se necessário refletir a cerca desta problemática vivenciada por esta comunidade, e tentar compreender a complexidade concernente a este aspecto que vem incomodando muitos moradores. Não obstante, é notória a deficiência da segurança pública, neste bairro, que precisa urgentemente ser solucionada.

Percebe-se que o bairro José Pinheiro, há pouco tempo, foi contemplado com alguns espaços e equipamentos públicos de esporte e lazer, o Complexo Desportivo Plínio Lemos, a nova sede do Clube de Mães. Frutos de uma luta constante da comunidade através de sua SAB e outras instituições representativas, o que pode ser instrumento de transformação social para esta população. Vê-se que o art.29 de nossa Constituição Federal é exercido nesse bairro, pois as associações representativas têm cooperado, ao longo dos anos, com o planejamento municipal e conquistado melhorias para o bairro.

Mesmo assim, diante da realidade apresentada neste estudo, observa-se que as ações concernentes as políticas públicas precisam ser refletidas e continuadas. Como lembra Marcellino (2006), os poderes públicos, no âmbito municipal, estadual e federal necessitam de relações existentes entre as associações locais, assim oportunizando aos sujeitos vivências e ações que podem oferecer possibilidades de práticas que democratizem diversos âmbitos ao compromisso e desenvolvimento social.

O bairro José Pinheiro tem alguns privilégios em relação a outros bairros estudados. No entanto, percebe-se uma urgente necessidade de manutenção, construção e reconstrução de vários equipamentos, como praças, quadras esportivas e playgrounds que estão mal conservados e podendo provocar acidentes aos usuários.

Alguns programas de governo têm um período limitado, como foi observado o caso do PELC, com duração de apenas um ano, interrompendo suas atividades para a comunidade, que necessita de uma continuidade destes tipos de programas. É necessário o amadurecimento e evolução destas iniciativas para políticas de Estado, que se perpetuem. 
Observa-se que o acesso à educação por meio das políticas públicas, como o Pró-Jovem, promovem ações que oportunizam aos adolescentes adquirir novos conhecimentos, podendo desenvolver uma visão crítica do mundo e alcançar uma formação técnica qualificada, viabilizando ainda serem inseridos no mercado de trabalho.

\section{Referências}

ALMEIDA, Alex Pina. Lazer, Escola e Animação Cultural: reflexões. In: Simpósio em Educação Física da EEFD, 1., 2003, Rio de Janeiro. Anais... Rio de Janeiro, 2003. CD-ROM.

AMARAL, Sílvia Cristina Franco. Verbete Políticas Públicas. In: GOMES, Christianne Luce (Org.) Dicionário Crítico do Lazer. Belo Horizonte: Autêntica, 2004.

CÂMARA MUNICIPAL DE CAMPINA GRANDE. Disponível em: <http:// www.camaracg.com.br/joia.php>. Acesso em: o3 fev 2009.

CAILLOIS, Roger. Os jogos e os Homens: a máscara e a vertigem. Lisboa: Cotovia, 1990.

CORRÊA, Roberto Lobato. O espaço urbano. São Paulo: Ática, 1989.

CÔRTEZ, Gustavo Pereira. et. al. Gerais de Minas: A Expressão Popular nas Manifestações Culturais. In: Encontro de Extensão da Universidade Federal de Minas Gerais, 7., 2004, Belo Horizonte, Anais... Belo Horizonte, 2004. CD-ROM.

CHEMIN, Beatris Francisca. Políticas públicas de lazer: o papel dos municípios na sua implementação. Curitiba: Juruá, 2007.

COSTA, Vera Lúcia M. Esportes da natureza e risco na montanha: uma trajetória de jogo com limites e incertezas. Tese (Doutorado). Universidade Gama Filho, Rio de Janeiro, 1999. 
DINIZ, Lincoln da Silva. As bodegas da cidade de Campina Grande: objetos de permanência e transformação do pequeno comércio no bairro de José Pinheiro. Dissertação (Mestrado). Universidade Federal de Pernambuco. Recife, 2004.

ELIAS, Norbert. O processo civilizador - formação do Estado e Civilização. Rio de Janeiro: Jorge Zahar, v. 2, 1993.

FREIRE, Paulo. Pedagogia da Autonomia: Saberes Necessários à Prática Educativa. São Paulo: Paz e Terra, 1996.

GONÇALVES, Maria Alice Rezende. A Vila Olímpica da Rosa e Verde. Rio de Janeiro: FGV, 2003.

IBGE - Instituto Brasileiro de Geografia e Estatística. Censos Demográficos 1991/2000. 2002.

MARCELLINO, Nelson Carvalho. Lazer e Educação. 12. ed. Campinas: Papirus, 2007.

O Lazer e os Espaços da Cidade. In: ISAYAMA, Helder; LINHARES, Meily Assbu (Org.). Sobre Lazer e Políticas: maneiras de ver, maneiras de fazer. Belo Horizonte: Editora UFMG, 2006.

MENDONÇA, Luiz César Pereira; et. al. Forró como Prática Corporal para a Terceira Idade: lazer e socialização. In: Anais do XX Encontro Nacional de Recreação e Lazer. São Paulo, 2008.

NASCIMENTO, Samara Queiroz; LEMOS, Elaine Melo de Brito Costa. $A$ Dança Popular nas Comunidades de Bairro: conhecendo a arte dançante em Campina Grande. Campina Grande: PIBIC/CNPq/UEPB, 2006.

PINTO, Leila Mirtes Santos de Magalhães. Políticas públicas de esporte e lazer: caminhos participativos. Revista Motrivivência: Políticas públicas: educação física/ esporte/ lazer. v. 10. n. 11 - setembro. Florianópolis, 1998 . 
ROBBA, F; MACEDO, S.S. Praças Brasileiras. 2.ed. São Paulo: Editora da USP: Imprensa Oficial do Estado de São Paulo, 2003.

SANTOS, José Luiz dos. O que é cultura. 14. ed. São Paulo: Brasiliense, 1994.

SECRETARIA NACIONAL DE DESENVOLVIMENTO DE ESPORTE E DE LAZER - SNDEL. PELC Catálogo - 2007-2008: Esporte e Lazer da Cidade. Brasília, 2008.

ZACARIAS, Lídia dos Santos. Crianças no Mundo da Rua: Socialização, cultura e Gênero. Dissertação (Mestrado) - Universidade Estadual de Campinas, Faculdade de Ed. Física. Campinas, 1999. 


\title{
Apropriação e resignificação dos espaços nas Malvinas: reflexões sobre a experiência do lazer
}

\author{
Denise Guimarães dos Santos \\ Elaine Melo de Brito Costa Lemos
}

\section{O surgimento da comunidade Malvinas}

O antigo Conjunto Álvaro Gaudêncio, hoje denominado bairro das Malvinas, é uma das comunidades mais populosas de Campina Grande, que segundo IBGE (2002) apresenta um número superior a $36 \mathrm{mil}$ habitantes. Localiza-se na zona oeste do município, e faz fronteira com as comunidades Dinamérica, Tambor e Ramadinha.

O modo como o bairro nasceu e a forma como se deu seu crescimento é um importante fator a ser localizado para o entendimento e a identificação dos problemas sociais e estruturais encontrados hoje no bairro Malvinas, bem como a relação que a comunidade tem com o lazer e o convívio social. O lazer apresenta como um de seus promotores o processo de urbanização estando intimamente relacionados, onde sua inclusão na observação da dinâmica cultural da sociedade precisa ser parâmetro para sua análise (BRUHNS, 1997). Reforçando essa discussão apresentada pela autora, Almeida (2008, p. 23) afirma que "a urbanização é um dos elementos chave para compreender o lazer. O lazer tem um amplo desenvolvimento na urbanização, absorvendo elementos da cultura, das artes e das relações sociais". 
O processo urbanístico apresenta estreita relação com o espaço e o tempo, onde suas características e nuances adquirem novos significados a cada momento temporal e espacial. Nesta dinâmica, Pellegrin (1999) inclui o indivíduo e a sociedade como um todo, que diante do tempo dialoga com esse espaço, estabelecendo além da interação uma apropriação do mesmo. A autora ainda discorre que:

Trava-se, pois, um diálogo entre seres humanos e espaços, através da História, impregnado de valores sócioculturais. A relação que se estabelece entre ser humano e espaço caracteriza-se por uma movimentação constante, algo assim como uma discussão infinita, onde permeiam os valores e os momentos de uma determinada sociedade.

Nessa perspectiva, os espaços utilizados, na comunidade, adquirem, para seus moradores, um significado próprio, revelando o sentimento de luta e conquista presente nos integrantes do bairro Malvinas. Para Rechia (2003, p.14), a existência dos espaços públicos depende do significado que a comunidade lhe concede, o qual "muitas vezes está relacionado com as formas de apropriação e o uso no plano da vida cotidiana, gerados ao longo do tempo, tornando-se referencial para o lugar".

Esse referencial delineia a forma como os moradores do bairro em foco agem em busca de seus ideais coletivos reivindicando seus direitos. Tal postura tornou-se motivo de orgulho e identidade para os moradores das Malvinas, o que fica bem representado nos spectos simbólicos ${ }^{1}$ de sua bandeira (Imagem 1) criada a partir de um concurso realizado nas escolas da comunidade, e na letra de seu hino, que existe desde 1987, com um trecho destacado a seguir:

1 Significado dos cinco pontos simbólicos na bandeira das Malvinas

- Escadas: representam as duas porteiras que fechavam o conjunto, que apresentava duas saídas vigiadas por policiais para impedir a saída e entrada de qualquer um dos invasores.

- Muro: falta de interesse dos políticos em resolver a situação.

- Escudo: proteção, organização dos moradores.

- Ferramentas: ter acesso e fazer a limpeza das casas.

- Mão: fé em Deus. 


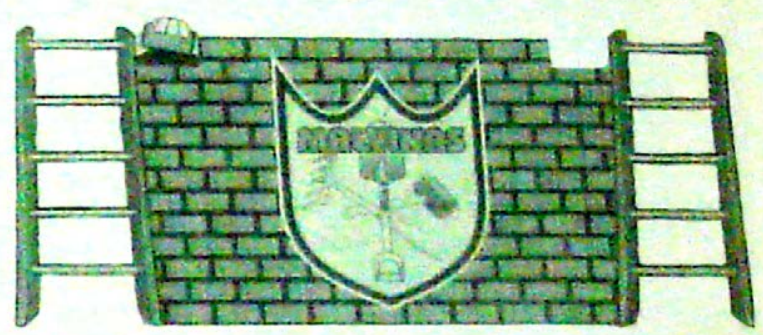

Imagem 01: Bandeira das Malvinas

Minha Malvinas querida
Relembro a sua invasão
Onde um povo bravo e unido
Conquistou sua habitação(...)
Muito lutou esse povo
Na época da invasão
Faltava luz, água e muito mais
Faltava no povo a paz
Hoje há paz, respeito e união(...)
Oh! Malvinas querida
Tu és fruto de um povo herói (...)

(Trechos do Hino do bairro das Malvinas)

O bairro Malvinas surgiu a partir de um conjunto de casas construídas pela CEHAP (Companhia Estadual de Habitação Popular) na década de 80. Esse conjunto era destinado aos servidores estaduais, porém quando foram concluídas as construções, em 1983, faltava infraestrutura mínima para habitação como água, energia e rede de esgoto. As casas não foram entregues aos servidores, e mediante a falta de providências dos órgãos competentes para a conclusão definitiva da obra, em 23 de março do mesmo ano, aconteceu a invasão deste conjunto habitacional.

A invasão foi realizada por famílias que afirmavam não ter onde morar; o processo de ocupação levou três dias com resistência a investidas do governo e cercos policiais, como visualiza-se na Imagem 
2. O conjunto continha 3.300 casas abandonadas, dispostas em uma área de 18 mil metros quadrados divididos em cinco conjuntos, Bodocongó I, II, III, IV e V; essas residências foram ocupadas por sem-tetos provenientes dos bairros de Santa Rosa, Bodocongó, Centenário, José Pinheiro, Pedregal e Cruzeiro. (MIGUEL; SILVA, 2007).

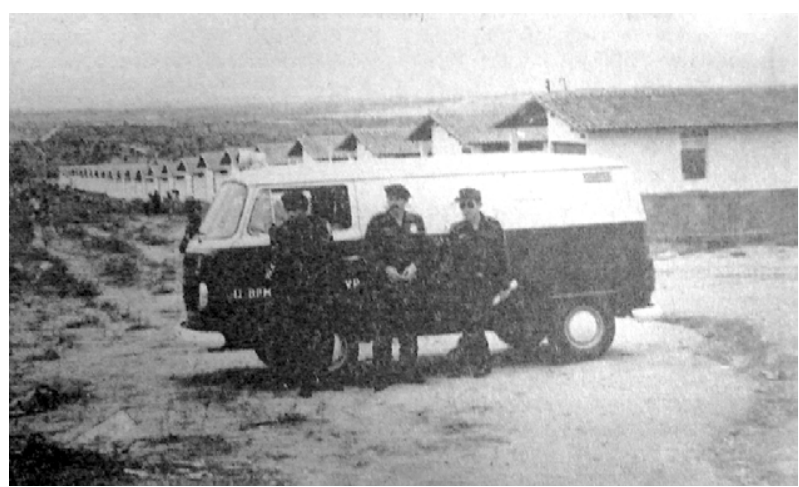

Imagem 02: Policiamento em uma das saídas do Conjunto Álvaro Gaudêncio.

Fonte: Gazeta do Sertão (1983)

As décadas, entre os anos 60 e 80, foram um período bastante marcado pelas invasões em Campina Grande, sobretudo em virtude de uma grande área da malha urbana (31\%) estar sob domínio de apenas 20 pessoas, sem desempenhar qualquer função social, além do grande déficit habitacional (MELO, 1988). O surgimento de movimentos por melhores condições de vida no que se refere a questões urbanas, como habitação e saneamento, nesse período citado e principalmente nos anos 80, é consequência da inexistência de uma política nacional capaz de observar os aspectos do desenvolvimento urbano. (NETO; CASTRO, 2007, p. 157)

Tais movimentos, gerados de forma espontânea ou planejada, foram movidos diante da extrema necessidade da população; ainda assim, conforme Melo (1988), existiam também os aproveitadores que tiravam vantagem do momento para obtenção de benefício próprio mediante a especulação imobiliária, mas essa foi uma situação não muito representativa, a qual era denunciada pelos próprios invasores. 
Outra forma de especulação imobiliária, em nosso entendimento, foi o fato de famílias, no momento da invasão, dividirem-se em busca de um maior número possível de casas; assim o pai ficava em uma, a mãe em outra, o filho em mais uma. Dessa forma seguiu até o momento da regularização das casas que só foi permitido o registro de uma residência por família; com isso as famílias foram obrigadas a se desfazerem das outras casas, e como não queriam perder nada as vendiam por valores irrisórios. Isso foi identificado na fala de um antigo morador do bairro, que segundo relato, sua própria casa foi adquirida em troca de uma bicicleta.

Após alguns meses de conflito, o governo cedeu o direito das casas às famílias mediante pagamento das prestações das mesmas. No momento de regularização, foi constatado que a maioria dos ocupantes não teria condição para quitar as casas simplesmente pelo fato de serem moradores de rua e não terem nenhuma renda.

Somente cinco anos depois, já no segundo mandato do governo responsável pela construção do conjunto, que a infra-estrutura mínima para atender aos moradores começou a ser implantada (MELO, 1988). O mesmo passou a ser bairro em 1987, através da Lei Municipal número 1.542, sancionada pelo prefeito da época.

O nome Malvinas veio do conflito militar, que ocorria na mesma época da invasão, o das Ilhas Falkland, popularmente conhecidas como Ilhas Malvinas, localizadas ao extremo sul da América Latina. Daí por diante, o bairro só fez crescer, e desordenadamente, refletindo numa ausência de política urbana, mesmo com parcerias na construção civil da CEHAP, Caixa Econômica, etc.

A comunidade cresceu, e atualmente o bairro apresenta oito conjuntos habitacionais (cinco da CEHAP e três da Caixa Econômica Federal), além de um loteamento particular (Grande Campina) com mais de 300 casas habitadas - os quais apresentam organizações comunitárias próprias; consequência disso foi a dificuldade para nossa pesquisa contactar as organizações que pudessem expor com mais detalhes a realidade do bairro como um todo. 0 bairro possui oito escolas (seis estaduais e duas municipais), cinco creches, cinco $^{2}$ centros de saúde,

2 Cinco centros de saúde que contemplam dez equipes de saúde; dado atualizado com a 
uma delegacia, uma rádio comunitária e muitos estabelecimentos comerciais. (MIGUEL; SILVA, 2007)

\section{Resignificações dos espaços para a vivência do lazer}

Atualmente a comunidade "concentra um número considerável de residência, a maioria das ruas é calçada, não há praças, nem sistemas aquáticos, há carência de árvores e os resíduos sólidos são descartados em terrenos baldios, apesar da coleta regular realizada pela prefeitura" (OLIVEIRA e SILVA, 2007, p. 218). Hoje analisando a estrutura física da comunidade percebe-se a despreocupação, por parte do poder público, com áreas específicas para a convivência social.

Considerando os discursos da direção da Escola Lafayete Cavalcanti, entrevista e pesquisa de campo, percebeu-se, nas Malvinas, essa carência de espaços e equipamentos destinados ao lazer dos moradores, e a maioria dos que existem não apresenta estrutura satisfatória para a experiência plena do lazer. A partir dessa percepção e dos dados coletados em campo, obteve-se o levantamento dos seguintes espaços e equipamentos de lazer:

\begin{tabular}{|c|c|c|c|}
\hline & Quant:" & Estado & Identificação do Espaço \\
\hline $\begin{array}{l}\text { Terrenos } \\
\text { Baldios }\end{array}$ & -- & $\begin{array}{c}\text { Espaços desnivelados, apresentando } \\
\text { mato, utilizados para criação de animais. } \\
\text { Há também os espaços de terra batida. } \\
\text { Há pontos com lixo }\end{array}$ & $\begin{array}{l}\text { Espaço identificado } \\
\text { pela gestora da escola e } \\
\text { pelos pesquisadores }\end{array}$ \\
\hline Ruas & -- & $\begin{array}{l}\text { As ruas, em sua maioria, são calçadas } \\
\text { ou asfaltadas. Algumas ruas de terra } \\
\text { apresentam esgoto a céu aberto }\end{array}$ & $\begin{array}{l}\text { Espaço identificado } \\
\text { pela gestora da escola e } \\
\text { pelos pesquisadores }\end{array}$ \\
\hline $\begin{array}{l}\text { Área da } \\
\text { escola }\end{array}$ & 1 & $\begin{array}{c}\text { Grande espaço livre com pátio em bom } \\
\text { estado de conservação. Contém um } \\
\text { tanque de cimento que as crianças pulam } \\
\text { de cima. }\end{array}$ & $\begin{array}{l}\text { Espaço identificado pela } \\
\text { gestora da escola }\end{array}$ \\
\hline
\end{tabular}

pesquisa de campo. Na época da publicação, 2007, existia apenas um centro de saúde. 


\begin{tabular}{|c|c|c|c|}
\hline $\begin{array}{l}\text { Giradouro } \\
\text { (Avenida } \\
\text { Floriano } \\
\text { Peixoto) }\end{array}$ & 1 & $\begin{array}{l}\text { Obra recente para organização da malha } \\
\text { viária local. Contém uma estrutura deco- } \\
\text { rativa e plantas ornamentais }\end{array}$ & $\begin{array}{c}\text { Espaço observado pelos } \\
\text { pesquisadores }\end{array}$ \\
\hline $\begin{array}{l}\text { Mercado } \\
\text { das Malvi- } \\
\quad \text { nas }\end{array}$ & 1 & $\begin{array}{l}\text { Espaço recentemente reformado, apre- } \\
\text { senta toda parte estrutural conservada }\end{array}$ & $\begin{array}{l}\text { Espaço observado pelos } \\
\text { pesquisadores }\end{array}$ \\
\hline $\begin{array}{l}\text { Lan-houses } \\
\text { e casas de } \\
\text { jogos ele- } \\
\text { trônicos }\end{array}$ & -- & Espaços privados & $\begin{array}{l}\text { Espaço identificado pela } \\
\text { gestora da escola }\end{array}$ \\
\hline $\begin{array}{l}\text { Rede de } \\
\text { canais } \\
\text { coletores }\end{array}$ & 1 & $\begin{array}{l}\text { A pista para caminhada apresenta gran- } \\
\text { des buracos para o esgoto, o que faz os } \\
\text { usuários caminharem no asfalto próximo } \\
\text { aos carros. }\end{array}$ & $\begin{array}{l}\text { Equipamento observa- } \\
\text { do pelos pesquisadores }\end{array}$ \\
\hline $\begin{array}{l}\text { Campos de } \\
\text { futebol }\end{array}$ & 9 & $\begin{array}{l}\text { Alguns apresentam traves, demarcações e } \\
\text { gramado. Outros apresentam apenas tra- } \\
\text { ves; existem também os espaços que não } \\
\text { têm nenhum elemento que identifique, } \\
\text { mas são utilizados pelos moradores como } \\
\text { campos de futebol }\end{array}$ & $\begin{array}{l}\text { Equipamento identifica- } \\
\text { do pela gestora da esco- } \\
\text { la e pelos pesquisadores }\end{array}$ \\
\hline $\begin{array}{l}\text { Campos e } \\
\text { quadras } \\
\text { de futebol } \\
\text { particu- } \\
\text { lares } \\
\end{array}$ & -- & $\begin{array}{c}\text { Apresentam toda a estrutura necessária } \\
\text { para a modalidade, com refletores e } \\
\text { campo gramado }\end{array}$ & $\begin{array}{l}\text { Equipamento identi- } \\
\text { ficado pela gestora da } \\
\text { escola }\end{array}$ \\
\hline $\begin{array}{l}\text { Quadra } \\
\text { de areia } \\
\text { presente } \\
\text { na escola }\end{array}$ & 1 & Com pouca areia e sem traves & $\begin{array}{l}\text { Equipamento identi- } \\
\text { ficado pela gestora da } \\
\text { escola }\end{array}$ \\
\hline $\begin{array}{l}\text { Ginásio po- } \\
\text { liesportivo } \\
\text { (CAIC) }\end{array}$ & 1 & $\begin{array}{c}\text { A cobertura do Ginásio apresenta } \\
\text { buracos pela degradação e sua estrutura } \\
\text { está enferrujanda. Em torno do ginásio } \\
\text { há grande quantidade de mato e alguns } \\
\text { pontos com lixo }\end{array}$ & $\begin{array}{l}\text { Equipamento observa- } \\
\text { do pelos pesquisadores }\end{array}$ \\
\hline $\begin{array}{l}\text { Canal do } \\
\text { Bodocongó } \\
\text { (trecho } \\
\text { final que } \\
\text { limita pe- } \\
\text { quena área } \\
\text { do bairro) }\end{array}$ & 1 & $\begin{array}{c}\text { Obra recente encontra-se em bom estado } \\
\text { de conservação. Apresenta pista de } \\
\text { caminhada e ciclovia }\end{array}$ & $\begin{array}{l}\text { Equipamento observa- } \\
\text { do pelos pesquisadores }\end{array}$ \\
\hline
\end{tabular}

Quadro 01 - Espaços e Equipamentos de Lazer: Quantidade e Qualidade

* Considerando a extensão territorial do bairro das Malvinas não foi possível quantificar alguns espaços utilizados pelos moradores em momentos livres, como por exemplo, as ruas. 
Focalizamos, nesse instante, pontos de reflexão sobre os espaços e equipamento de lazer destacando alguns deles. Iniciemos, então, pelo relato da Diretora da Escola Municipal:

Não existem áreas de lazer no bairro, embora não more aqui, mas eu conheço o bairro em todas as suas dimensões e sei que tem muitos problemas, então um dos grandes problemas do bairro das Malvinas é a questão da área de lazer, nós não temos no bairro uma praça, nós não temos um parque, nós não temos uma quadra, eles jogam assim nos campos, sem nenhuma estrutura.

É perceptível, neste discurso, a menção da praça e dos parques como espaços que remetem o desenvolvimento das relações sociais e do espírito de comunidade, como trata Gastal (2005), a praça se mantém como fixa, pois está solidamente consolidada no imaginário urbano e se configura como elemento central da cidade. Diante da inexistência da praça, os moradores criaram estratégias que promovam interações entre os sujeitos na comunidade Malvinas. Percebemos, então, a apropriação e resignificação das encostas dos canais como espaço de encontro onde sentam, conversam e andam de bicicleta, como é observado na Imagem 03, usufruindo de alguns aspectos que por definição uma praça pode oferecer, como por exemplo, conversas, encontros, discussões ou simplesmente para passar o tempo, conforme trata Sousa (2004).

Mesmo identificando que os moradores atribuíram outros significados a tais encostas de canais, o estudo defende a existência de um espaço específico, urbanizado para a finalidade da praça ou do parque, considerando sobretudo os anseios daqueles que irão desfrutá-los. Entendemos a urgência de potencializar a experiência de divertimento, de descanso, de desenvolvimento humano a partir da ação do poder público em parceria com o privado, o terceiro setor e a comunidade, pois como enfatiza a mesma imagem 03, esse convívio humano que acontece embaixo das árvores é um canteiro que divide duas pistas asfaltadas que pressupõe movimentação constante de veículos, colocando em risco a segurança dos que ali compartilham suas vivências. 


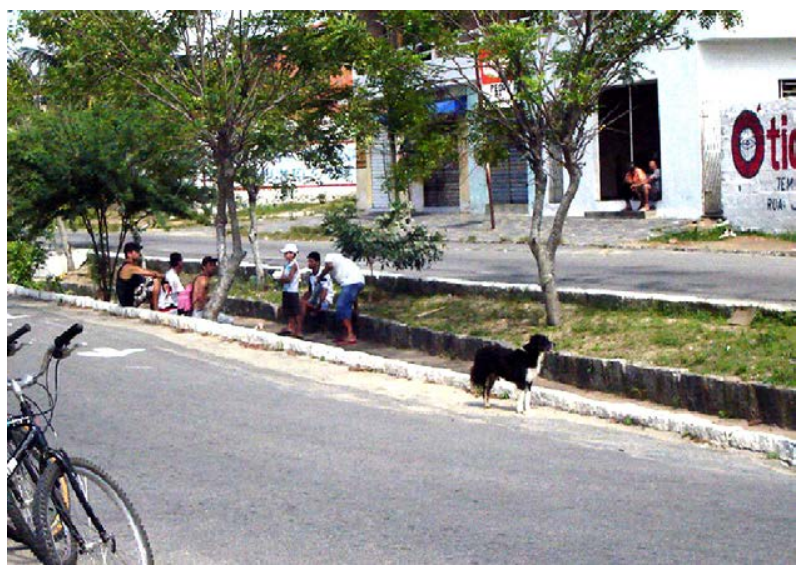

Imagem 03: Moradores sentados nas encostas do canal.

Fonte: Arquivo GCEM

O Mercado das Malvinas também foi resignificado pelos moradores do bairro, configurando-se como um espaço para além do ato de compra e venda de mercadorias, ao promover o convívio social, manifestações culturais e palestras sobre educação, saúde e serviços sociais públicos. Afirmamos, então, que, com base em Marcellino et. al. (2008), o Mercado das Malvinas trata-se de um caso de adaptação ou de novo uso pelos moradores, de um espaço planejado para um fim diferente do qual é utilizado. Esse espaço concebido para o aspecto comercial é também um espaço de lazer e de prestação de serviços públicos ligados à saúde e educação. É um espaço multifuncional. Apesar disso, não se diminui a necessidade de espaços e equipamentos de lazer para o bairro, viabilizados por políticas públicas.

Persiste então a discussão sobre espaço de lazer ideal e o que acontece, no cotidiano da comunidade, o espaço de lazer real. Nas Malvinas, não existem tantos espaços projetados para o lazer, no entanto o lazer é vivenciado seja na extensa rede de canais que integram o espaço público, nos descampados utilizados de diversas formas, ou no Mercado das Malvinas onde pequenos shows são promovidos. Ainda assim não se descarta a obrigação do poder público e suas parcerias em propiciar melhores condições de lazer, o espaço ideal; como por exemplo, o aproveitamento dos espaços que são utilizados para os momentos 
livres, os quais já são compreendidos pelos indivíduos como tal, para a construção de quadras, parques e praças.

Os espaços e equipamentos de lazer são importantes por proporcionarem diferentes formas de uso favorecendo a interação dos indivíduos. No entanto, percebe-se que essas dimensões do lazer não se configuram como prioridade nas ações de políticas públicas da cidade de Campina Grande.

Os espaços públicos não são pensados para se tornarem locais de permanência e convívio social, os quais, conforme argumenta Lima (2006) em sua tese, são especulados pelo poder público para a ampliação de espaços de passagem ou circulação, como ruas de acesso e alargamento de avenidas. Quando são planejados para o fim de interação social e lazer, esses espaços geralmente não apresentam estruturas necessárias para tal uso, como "bancos, fontes de água e bebedouros, ou arborização, quadras poliesportivas, etc. Nessas condições, não se tornam áreas convidativas à permanência e, consequentemente, à convivência social" (p. 86).

As quadras e campos de futebol bem como os terrenos baldios existentes, no bairro, ainda não sofreram intervenção do poder público, sendo mantidos pela própria população para seu uso da forma possível. Nesses espaços, ocorrem os torneios de futebol das Malvinas, como também as brincadeiras populares observadas pela pesquisa de campo.

Essas brincadeiras foram citadas pela Diretora da escola como atividades que as crianças exerciam dentro da escola, como destacadas no trecho a seguir:

...brincam no pátio, brincam de corda, brincam de bola, brincam de bolinhas de gude... sem nenhuma orientação... futebol é o preferido deles. E tem outros joguinhos que eles gostam muito que eles chamam de jogo de prego, é como se fosse um campinho, um tabuleirozinho, todo marcadinho com pregos.

Com as visitas à comunidade, observou-se que essas brincadeiras também eram vivenciadas pelas crianças nas ruas, como destacado na 
Imagem 04. Assim, as atividades que ocorrem dentro da escola citadas pela Diretora, refletem a vivência destas crianças em outros momentos fora do ambiente escolar, apesar da mesma alegar que, quando fora de horário escolar, as crianças não têm nenhuma outra ocupação senão as casas de jogos e lan-houses ou assistir televisão em casa, observado na seguinte afirmação:

Eu acredito que nesse tempo livre estão nas lanhouses ou nos mini-games ou não sei o que elas fazem, talvez diante de uma televisão... lamentavelmente as crianças não dispõe de nenhuma área de lazer.

Considerando importante essa troca de experiências da criança, acreditamos que a escola possui uma função social e pedagógica no sentido de reconhecer o cotidiano lúdico e transformá-lo em conhecimento que forme, eduque a criança para o lazer numa perspectiva de desenvolvimento humano.

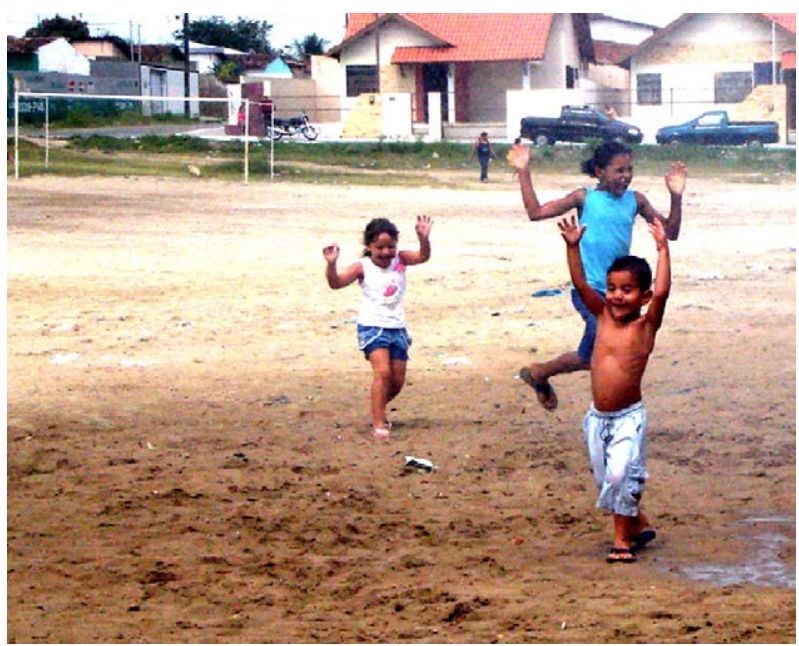

Imagem 04: Crianças brincando: a ambivalência do riso.

Fonte: Arquivo GCEM 
Rechia (2006) em seu estudo que trata o jogo dentro do ambiente escolar, discorre que a escola representa também um espaço de recriação das práticas sociais, e o jogo, vivenciado também fora da escola, potencializa as relações pessoais, possibilitando condições significativas para a formação humana. A autora ainda destaca que...

...essas práticas são oriundas da cultura popular, as quais são conseqüências de um processo histórico, provindo da experiência do brincar, jogar e divertirse com o próprio corpo em tempo/espaços diversificados. As crianças demonstram-se criativas, inventivas e autônomas e repassam aos colegas jogos e brincadeiras vividos fora da escola, ou seja, na rua, na praça, na própria casa.

Ainda inspirando-se na imagem 04, não podemos passar despercebidos quanto às condições deste equipamento de lazer: extensa área, trave de futebol, pedras, buracos, lama no exato local onde as crianças brincam. De um lado, a alegria, o prazer, a vivência do lúdico de forma aparentemente inquestionável; do outro, os riscos do terreno acidentado e com lama, podendo trazer danos à saúde e à segurança. Essa imagem nos remete à ambivalência do riso discutida por Bauman (2003) baseando-se em Milan Kundera na qual trazemos para a vivência do lazer. 0 riso destas crianças pode representar o lado mau, em função daquele espaço e equipamento não serem "componentes dinâmicos de uma política pública de lazer" (Marcellino et. al., 2008) ideais e confiáveis como talvez gostariam que fossem, mas há, também no mesmo riso, um lado bom, no sentido em que tal espaço e equipamento permitirem o brincar com o outro, tornando-se menos problemáticos quanto parecem.

O Giradouro localizado, no trecho final do Canal de Bodocongó (imagem 5) juntamente com a extensa rede de canais coletores do bairro (imagem 6), configuram-se como umas das poucas ações do poder público, nas Malvinas, no que se refere à organização da malha viária e à saúde pública. 0 objetivo principal foi a revitalização dos canais pelo desenvolvimento urbanístico trazendo benefícios no aspecto da saúde coletiva. Esses locais foram apropriados e resignificados pelos moradores sendo muito utilizados para atividades de caminhadas e 
passeios de bicicleta, bem como brincadeiras infantis, e também ponto de encontro para momentos de descontração.

Outro espaço identificado, no bairro, e bastante utilizado pelos moradores, mesmo diante de sua precária conservação, é o Centro de Atenção Integral à Criança, o CAIC, que apresenta uma estrutura considerável contemplando um ginásio poliesportivo, uma quadra de areia e um espaço utilizado como pista de skate. O CAIC é um espaço utilizado para realizações de eventos do bairro como copas de futsal, movimentos religiosos e manifestações de cunho público, como palestras educativas e prestações de serviços promovidos pelo poder público.

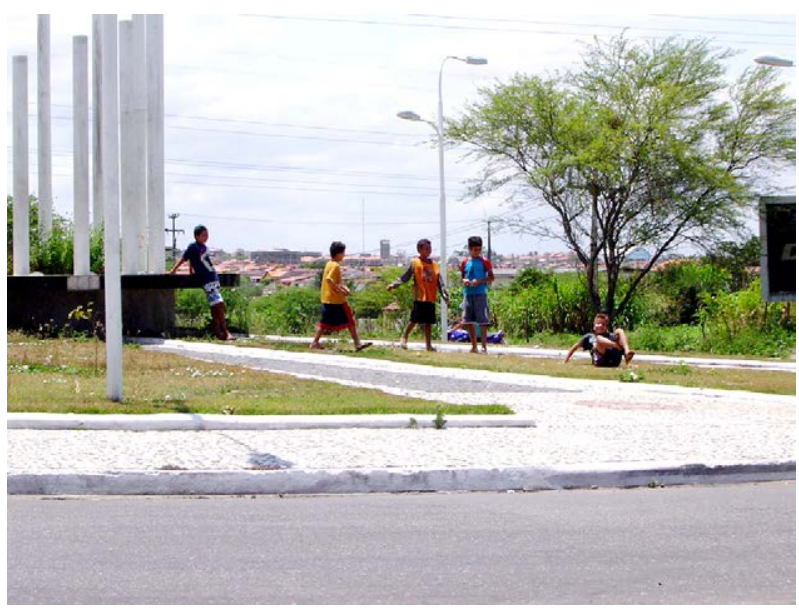

Imagem 05: Crianças brincando no giradouro

Fonte: Arquivo GCEM 


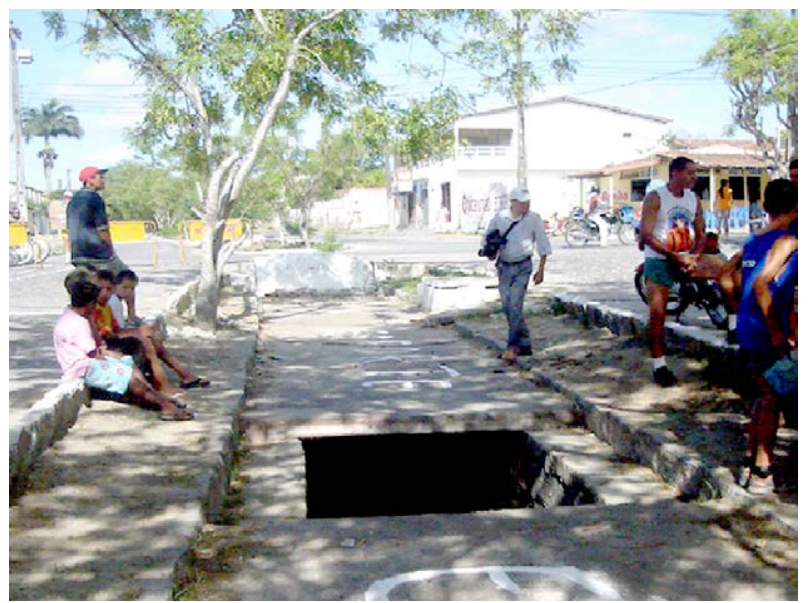

Imagem 06: Trecho do canal deteriorado: o convívio social em meio ao perigo e ao mau cheiro.

Fonte: Arquivo GCEM

Com exceção do Canal do Bodocongó, do Giradouro e do Mercado das Malvinas, é possível observar a má conservação dos demais espaços e equipamentos, mesmo aqueles que tiveram, em algum momento, intervenção do poder público, como é o caso da rede de canais coletores do bairro.

A manutenção desses espaços em estado precário não se configura como uma ação ativa por parte do poder público; prova disso é a situação da rede de canais que apresenta vários trechos de sua extensão danificados com exposição do córrego que passa por baixo da pista para caminhar, como é visualizado na Imagem 06 , o que pode causar acidentes com adultos e crianças bem como expor a população a condições de pouca higiene. Outro exemplo bem significativo é o CAIC, que além de apresentar toda sua estrutura deteriorada, apresenta seus arredores com um extenso matagal e pontos de lixo acumulado, demonstrando estado de abandono. Diante desses dois exemplos apresentados, destaca-se a obrigatoriedade do poder público em agir objetivando o reverter essas situações; como também o dever da população com tais espaços e equipamentos, entendendo que por serem públicos, trata-se de bens coletivos, caracterizando como obrigação de todos (poder público, setor privado e sociedade) o cuidado com os mesmos. 
Não poderíamos deixar de refletir sobre a importância do espaço e equipamento fundamentando-nos, nesse instante, em Marcellino et. al. (2008), como sendo componentes dinâmicos de política pública de lazer em diálogo permanente com a política urbana. Um dos eixos norteadores relacionados a tais componentes é a sua democratização e a participação das comunidades na concepção de políticas públicas. De acordo com os autores, a democratização do lazer implica em democratização do espaço, onde o lazer efetiva-se na correspondência entre o tempo e o espaço disponíveis.

Dialogando ainda com os autores supracitados e focalizando o olhar para as Malvinas, a relação entre lazer e espaço urbano, nesta comunidade, existem lacunas causadas pelo próprio crescimento do bairro, como apresentado no início deste texto, em que a aceleração da população não vem acompanhada pelo desenvolvimento planejado de sua infraestrutura adequada, porém ainda percebem-se espaços vazios no bairro, mas não se trata de espaços urbanizados.

Analisaremos, logo em seguida, a participação popular na reivindicação e conquista de espaço e equipamento de lazer para as Malvinas, mas antes queremos lembrar o uso multifuncional do espaço público, onde nesta comunidade, a rua e o mercado públicos são locais de encontro, de prazer, de informação, de festa. As Malvinas ainda apresentam o espaço para além da circulação e de trabalho que foram resignificados pelos moradores. Portanto, o estudo acredita que ainda dá tempo de ser constituída e efetivada uma política pública de lazer, na cidade de Campina Grande, juntamente com a política urbana que concilie o crescimento do bairro com os espaços e equipamentos (destacados nesse texto) com potencial para a experiência do lazer para o desenvolvimento humano e a transformação social.

\section{O lazer como objeto de reivindicação social: a participação de entidades comunitárias}

Desde o surgimento das Malvinas, percebe-se uma atitude de luta dos moradores, que mesmo diante de situações adversas e condições 
sócioeconômicas restritas, buscam a melhoria e o bem-estar coletivo numa mobilização social que, por sua vez, significa, de acordo com Toro e Werneck (2007), um agir em função da ação coletiva em busca de um propósito comum, quando pessoas da comunidade decidem e agem com um objetivo comum, buscando, no dia-a-dia, tomadas de decisões e desejos coletivos.

Por muito tempo a população, que só crescia, exigiu melhorias nas condições da comunidade, expondo a necessidade de beneficiamento na infraestrutura da mesma, como pavimentação das ruas e recuperação da rede de drenagem pluvial.

A mesma exigência foi feita no que se refere à rede de canais construídos na maioria dos córregos do bairro; quando os canais foram cobertos, a comunidade foi beneficiada, não só no aspecto da saúde, pela questão de deixar as ruas mais limpas, e transformarem-se, posteriormente, em um dos poucos pontos de lazer por meio da prática da atividade física (caminhadas e ciclismo). Como aborda Chemin (2008), a promoção da saúde objetivando o bem-estar e desenvolvimento humano, sob encargo do poder público e da sociedade como um todo, considera a eficaz realização do lazer a todos os indivíduos, podendo possibilitar a vida mais saudável destes.

A promoção da saúde se destina a atuar nos determinantes da saúde e criar alternativas saudáveis para a população, com ações e condições relacionadas à saúde, abrangendo os conteúdos sóciopolíticos, ecológicos e sócioculturais. Nessa perspectiva, a intervenção nos canais coletores das Malvinas bem como a inserção de novos elementos desta natureza, no bairro, caracterizariam ação voltada à promoção da saúde, pois disponibilizariam condições para uma vivência saudável transcendendo a visão biologicista, bem como, ampliando a definição de saúde para além da OMS (Organização Mundial da Saúde) como sendo um estado de completo bem-estar físico, mental e social e não apenas a ausência de doença ou enfermidade, que corroborando com Palma et. al. (2003), tal definição deixa implícita a inviabilidade deste propósito ser atingido em função da expressão completo bem-estar, além da dimensão social desta definição parecer surgir somente para incorporar uma das vertentes da vida do ser humano sem considerar, 
com profundidade, sua dinâmica e relevância para compreensão do fenômeno.

Nesse sentido, compartilhando com as reflexões de Palma et. al. (2003, p. 25), a dimensão da saúde deve transcender a visão linear puramente anatomo-fisiológica, pois a promoção da saúde está ligada a um conjunto de ações do poder público destinado à viabilização de políticas voltadas para a melhoria da condição de vida da sociedade, com o reconhecimento desse direito; assim "ao se tratar de promoção de saúde não se ressalta somente a cobertura e acesso aos serviços de saúde, mas, antes, as inter-relações com a equidade social". Destaca-se ainda, de acordo com os autores, o fenômeno saúde, na VII Conferência Nacional, como resultante de várias condições da vida humana, dentre elas, o lazer. Entendemos, então, que saúde, lazer, educação, dentre outras são dimensões existenciais que devem dialogar entre si, pois suas interfaces delineiam o desenvolvimento humano e efetivam a transformação social.

Reforçamos, então, a urgência do diálogo entre política pública de lazer, de saúde, de educação e a política urbana, não somente no sentido de implementar, mas de acompanhar e avaliar as ações desenvolvidas, e ao mesmo tempo, da inserção e participação popular. Tais políticas também devem contemplar os propósitos de manter aquilo que foi promovido, tanto estruturalmente quanto ao uso e ações desenvolvidas. Por exemplo, a falta de manutenção nos canais do bairro das Malvinas, como destacado na Imagem 06, permitiu que muitos trechos apresentassem deterioração, o que pode provocar acidentes graves, e acaba limitando sua utilização de modo pleno; isso reduz mais ainda as possibilidades que o equipamento público pode trazer para o lazer, a saúde e a segurança na comunidade.

Esse propósito de manutenção também é motivo para mobilização social nas Malvinas, sem deixar de ressaltar o papel desses atores sociais em manter o espaço público juntamente com o poder público e a comunidade. Em um processo de mobilização social, de acordo com Toro e Werneck (2007), a busca pelo bem comum não é um papel necessariamente desempenhado por uma pessoa, como nesta pesquisa pelo presidente da SAB ou do Clube de Mães, é possível que um grupo de pessoas ou instituições estejam desempenhando tal papel con- 
juntamente. Outro aspecto destacado pelos autores pertinentes a essa discussão é que os espaços públicos não podem ser confundidos pela sociedade como espaços do governo, o que acarreta a espera das ações governamentais para com o cuidado do que é público, que na verdade deve partir também do coletivo por se tratar de espaços de/para todos.

Essa mobilização coletiva foi observada, nas Malvinas, a partir dos estudos de Miguel e Silva (2007), que apontam as reivindicações conquistadas - a pavimentação e calçamento das ruas bem como a cobertura da rede de canal - foram benefícios conseguidos através dos movimentos organizados da comunidade, liderados pela Associação dos Moradores, Núcleo de Mulheres, Grupo de Apoio Comunitário e Clube de Mãe Master Crister.

É oportuno mencionar que tal referência foi utilizada para fundamentação sobre o cotidiano do bairro, uma vez que, realizamos inúmeras tentativas de contatos e agendamentos para entrevistas com o presidente da $\mathrm{SAB}$, mas todos sem sucesso. Íamos até o local, mas o mesmo nunca comparecia. Da mesma forma que reconhecemos que interesses políticos podem estar envolvidos nestas conquistas, pois muitos dos representantes de entidades comunitárias anseiam cargos políticos.

Retomando as referências de Miguel e Silva (2007), abordam também que, mesmo diante das conquistas, os moradores continuam mobilizados em busca de mais melhorias para a comunidade. Os moradores ainda reivindicam do poder público e autoridades competentes, através do Grupo de Apoio Comunitário, mais ações para o bairro, entre elas a construção do Parque da Criança II $^{3}$ e da segunda etapa do Canal de Bodocongó ${ }^{4}$, prometida pelo atual prefeito, onde suas obras estão paralisadas. Também reivindicam a manutenção e ampliação dos campos de futebol com quadras de areia, criação de Conselho Munici-

30 Parque da Criança é o maior parque existente em Campina Grande, com uma área de $6.700 \mathrm{~m}^{2}$. Foi fundado em 1993 e se apresenta como um complexo, que abrange equipamentos como pista de caminhada, quadras esportivas, pista de skate, entre outros; também apresenta-se como um ótimo espaço para a realização de eventos recreativos e culturais para a comunidade de todo o município.

4 A segunda etapa do canal de Bodocongó irá beneficiar diretamente a comunidade das Malvinas, pois sua construção seguirá pela linha limítrofe do bairro, dando continuidade a primeira etapa que já apresenta seu trecho final nessa linha periférica. 
pal de Segurança para a implantação, no bairro, da Polícia Comunitária, além das exigências quanto ao transporte público.

Uma recente e aparente conquista para as Malvinas foi a liberação de verba para a construção do segundo complexo esportivo da cidade, a Vila Olímpica das Malvinas, que se caracteriza como uma consequência das ações da população bem como do poder público. 0 projeto, que visa investir na formação social, pretende beneficiar toda a comunidade com a promoção de esporte, saúde e lazer, oferecendo 17 modalidades esportivas. Esse complexo terá a mesma estrutura apresentada no Complexo Esportivo Plínio Lemos, a primeira Vila Olímpica de Campina Grande, localizado no bairro do José Pinheiro, contemplando campo de futebol, piscina para fins terapêuticos e recreativos, pista de atletismo, ginásio com quadra poliesportiva, salas para práticas de artes marciais, pista de skate, quadras de futebol de areia e vôlei. Esperase que o poder público de fato transforme a liberação da verba numa ação concreta.

Afirmamos então, inspirados em Marcellino (2007), que o lazer, nas Malvinas, tem se tornado objeto de reivindicação relacionado à qualidade de vida no bairro. Focalizemos então, nesse instante, nosso olhar para a reivindicação da construção do Parque da Criança II e da Vila Olímpica, bem como a ampliação dos campos de futebol e quadras de areia para perceber e refletir que a comunidade Malvinas possui um agir para o lazer, mesmo talvez desconhecendo a Constituição Federal que garante o lazer como um direito a todos. Podemos dizer que eles persistem na conquista deste direito independentemente do fato de conhecer ou não a lei constitucional, pois antes da lei, vem um desejo, uma necessidade legítimos da comunidade em desenvolver-se na condição humana e transformar-se socialmente, e para isso investe suas conquistas em moradia, saúde, segurança, e na mesma esfera de relevância, o lazer.

A especificidade concreta do lazer, considerado em sua manifestação na sociedade atual, é colocada como reivindicação social. Portanto, seu significado é bastante diferente do entendimento da Antiguidade Clássica. É uma questão de cidadania, de participação cultural (MARCELLINO, 2007, p. 12) 
Destacamos, ainda, que as reivindicações da comunidade e a operacionalização delas por parte do poder público, a exemplo, a criação da Vila Olímpica das Malvinas, trarão grandes avanços para a cidade de Campina Grande no que se refere à gestão e promoção do esporte e do lazer, principalmente considerando as informações do município alusivas a esses mesmos temas, presentes no Suplemento de Esporte da Pesquisa de Informações Básicas Municipais - MUNIC 2003 (2006) que, por sua vez, traz, dentre vários aspectos, um levantamento sobre o conhecimento da quantidade precária dos equipamentos esportivos na cidade de Campina Grande.

A participação de atores sociais no planejamento e execução de políticas públicas de lazer torna-se cada vez mais explícita e urgente, pois são eles que reconhecem seus anseios e projetos de vida coletivos que se materializam nas reivindicações e conquistas nas Malvinas. Afirmam Toro e Werneck (2007, p. 39) que "as pessoas não estão necessariamente de acordo entre si, mas de acordo com alguma coisa, com uma ideia, que é colocada acima dessas divergências", e entendem que a busca e a conquista do bem coletivo interferem no desenvolvimento humano.

Acreditamos que as Malvinas seja um bairro emblemático para a nossa pesquisa no sentido da palavra comunidade, tratado por Bauman (2003). As Malvinas não se revelam uma comunidade num entendimento romântico, constituído somente de significados e sensações boas, pois esta comunidade, que é humana, não pode realizar a esperança, mas ao mesmo tempo, não deixa de tê-la, considerando as reflexões deste autor. No cotidiano das Malvinas, são identificadas suas tensões comunitárias no sentido de buscar soluções corretas para o lazer, saúde, segurança, etc. A comunidade continua tentando junto ao poder público o bem que julga ser comunitário, considerando a pluralidade de perspectivas e desejos de seus atores sociais.

Bauman (2003, p. 11) afirma que para o dilema entre comunidade e individualidade

[...] uma boa coisa a fazer, contudo, é avaliar as chances e perigos das soluções já propostas e tentadas. Armados de tal conhecimento, estaremos aptos ao 
menos a evitar a repetição de erros do passado; ou mesmo tentar evitar ir muito longe por caminhos que podem ser percebidos por antecipação como sem saída.

\section{A festa da invasão: experiências de lazer e cultura}

A comunidade de bairro Malvinas completou em março de 2009 seus 26 anos de ocupação. A data de aniversário foi comemorada com diversos eventos, durante uma semana, foram promovidas pela prefeitura da cidade ações que visam o acesso à população de serviços ligados à saúde, educação e cidadania, como as cirandas de serviços e palestras educativas, com a participação das Unidades Básicas de Saúde, das escolas e das entidades comunitárias. Tais ações ocorreram em múltiplos espaços existentes no bairro, entre eles o Mercado das Malvinas, onde se encontra implantado o Espaço Cidadão para emissão de documentos. Ocorrem também manifestações promovidas pelo setor privado, como pequenos shows e patrocínios aos eventos, e pelos próprios moradores e entidades comunitárias, que desenvolvem atividades recreativas.

A festa da ocupação das Malvinas tem como encerramento um grande evento que marca a luta e a perseverança dos moradores da comunidade, que é a 'X Corrida do 26o Aniversário de Ocupação das Malvinas', destacada nas imagens 07 e 08. A corrida, promovida pelo Grupo de Apoio Comunitário (GAC) e Associação dos Moradores, é reconhecida como um dos eventos significativos do esporte no bairro, atraindo atletas pertencentes a cidades circunvizinhas e distritos. Percebemos, então, que a comunidade se organiza para propiciar não somente aos seus moradores uma reunião comemorativa marcando e lembrando o que ela representa como um acontecimento histórico e contínuo de buscas e conquistas por moradia, lazer, saúde, educação, etc. 


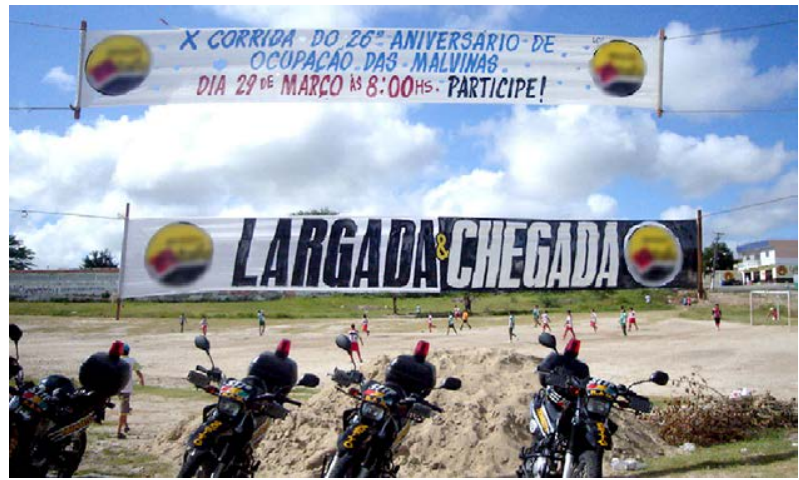

Imagem 07: Faixa do evento comemorativo e ao fundo partida de futebol com moradores das Malvinas.

Fonte: Arquivo GCEM

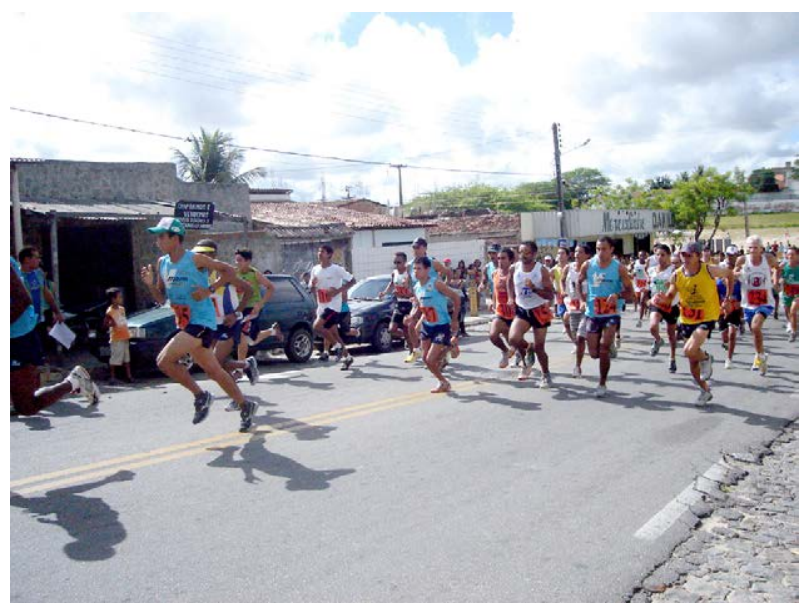

Imagem 08: Momento da largada - Pelotão masculino.

Fonte: Arquivo GCEM

De acordo com Rosa (2007), a festa desencadeia uma intensa movimentação de culturas, cuja relevância, no cenário histórico-cultural do Brasil, manifesta-se numa prática que propicia a construção e afirmação de identidades, dentre outras características. Assim como a festa do 'Maior São João do Mundo' promove a afirmação e identificação 
da cultura nordestina e o reconhecimento a cidade de Campina Grande pela população, turistas, agências de turismo; o evento da Corrida de aniversário de Ocupação das Malvinas reafirma sua identidade invasora de moradia, de lazer, de cultura.

De forma alguma, tal identidade das Malvinas soa, para nós, como algo pejorativo, muito pelo contrário, desde o seu surgimento, o sentido da invasão por moradia tem sido incorporado para outras esferas da vida humana neste bairro, como já destacado nesse texto, e nesse instante, retoma-se para a dimensão da cultura e do lazer.

Dialogando com o pensamento de Silva (2008), essa atitude de invasão presente, nas Malvinas, dá-se no entendimento que o espaço é fruto do modo como seus moradores o utilizam e do aspecto simbólico diante apropriação dos mesmos, surgindo, assim, o espírito de pertencimento, e abrindo portas para os vários tipos de usos e manifestações possíveis de serem realizados. Tais manifestações podem ser situadas como "espaços vividos e vivificados pelas tensões que são próprias do lugar" (p. 98), o que, em nosso estudo, reflete a construção e a incorporação da identidade das Malvinas.

O esporte mais praticado, no bairro, é o futebol. Um breve passeio pelas ruas das Malvinas denuncia este fato, onde campos com uma certa estrutura (com traves e demarcações) e descampados com pedras que marcam as traves, e animais (cachorros e jumentos) no mesmo espaço, são utilizados principalmente nos finais de semana pelos moradores em torneios e amistosos promovidos pela comunidade.

Essa prática se vale desde a época da invasão, onde já no primeiro fim de semana estavam os atletas de domingo no descampado. 0 primeiro time do bairro foi o "Invasores Futebol Clube" e seu campo ficava onde hoje se encontra o CAIC. Esse time que não existe mais é um exemplo também emblemático, juntamente com a escola de samba "Invasores do Samba" que, por sua vez, expandiu a participação de integrantes de outros bairros, da identificação que a comunidade tem com sua própria história, dando ao termo "invasor" um sentido não depreciativo que revela, na verdade, a própria identidade do bairro das Malvinas e de seus moradores. 
Atualmente as Malvinas contam com mais de dez times estabelecidos, onde os que apresentam melhor organização são os "Veteranos" e "10 de Maio", os quais possuem sede própria, troféus e campos estruturados com grama, traves com redes, demarcações, iluminações, etc.

Como reflexo dessa intensa prática do futebol, no bairro das Malvinas, foi criada a Escolinha Malvinense de Futebol, que se tornou um elemento importante para o desenvolvimento do esporte na comunidade. A mesma foi fundada, em 28 de outubro de 2006, pela Associação dos Feirantes das Malvinas, e conta com um diretor de esportes. A escolinha realiza trabalho voluntário, na comunidade, ensinando às crianças algumas modalidades esportivas; elas têm a oportunidade de participar de torneios de futebol de campo, damas, dominó e voleibol, além de outras atividades de lazer (MIGUEL; SILVA, 2007). Esse é mais um exemplo da ação comunitária em benefício do coletivo, o que promove o desenvolvimento das relações sociais bem como a transformação do indivíduo que faz parte desse processo e do conjunto social que realiza tal iniciativa.

Uma aliada na promoção dos eventos e manifestações culturais que acontecem, no bairro das Malvinas, é a rádio comunitária, que além dessa ação, tornou-se mais um espaço para as manifestações e reivindicações da população do bairro. A rádio foi fundada em, 7 de junho de 2003, e entrou no ar com o trabalho de pessoas da própria comunidade que não tinham experiência, mas, aos poucos, foram se adaptando e profissionais e estudantes de comunicação foram transformando a rádio comunitária um espaço profissional. A rádio comunitária se tornou um elemento a mais na percepção de conjunto do bairro das Malvinas o que, a priori, se caracteriza como uma das funções sociais de uma rádio comunitária. Em seus escritos, Bahia (2008) conclui que ao tratarem assuntos e informes de interesse do bairro, as rádios comunitárias ampliam os vínculos dos indivíduos com a comunidade, contribuindo "para a mobilização social e para a construção da identidade pessoal e coletiva".

O esporte, nas Malvinas, revela-se como um forte conteúdo cultural de lazer, presente nos eventos, no cotidiano e nas escolinhas esportivas. Mas, não podemos deixar de relembrar as manifestações da dança e outras formas de artes apresentadas, no Mercado das Malvinas, 
apontadas anteriormente. Como trata Marcellino (2008), a questão do lazer deve contemplar as múltiplas esferas culturais somadas aos conteúdos culturais do lazer: o esporte, o turismo, as artes, no sentido de formular políticas de atuação, considerando "a abrangência do lazer e seu entendimento parcial e limitado, que pode ser destacado na ação de órgãos públicos, na pesquisa, na legislação etc." (p. 11).

No que se refere à festa de aniversário das Malvinas, seguindo com a abordagem de Rosa (2007, p. 196-197), pode ser compreendida como um espaço de luta política e de reivindicação, local de encontro de moradores, tempo/espaço de consumo e produção, experiência de lazer, de espetáculo. A festa revela-se como um eixo constitutivo de políticas de lazer, pois sua dinâmica requer

planejamento, programação, organização e estruturação, que proporcionam divertimento, prazer, trabalho, protesto, comemoração, devoção, euforia, transgressão, reinvenção, excesso, criatividade e alegria: elementos que não se apresentam isolados ou em oposição, mas em tensão permanente, por ser a festa um tempo/espaço de ambigüidades. A diversidade pronuncia-se nos diversos tipos festivos, bem como nas manifestações e experiências que abarca, na coexistência e conflito de culturas que se confrontam.

\section{Considerações finais}

A comunidade de bairro Malvinas teve um surgimento polêmico desencadeado pela expressão 'invasão'. O que de início pode soar pejorativo, os moradores foram atribuindo outros significados: apropriação, pertencimento, não somente de moradia, mas também de saúde, malha viária, lazer, etc. Diante da problemática central da pesquisa percebemos que as interfaces entre lazer, educação e saúde reveladas, no cotidiano desta comunidade, possuem fissuras que necessitam de um agir político não de forma linear, mas sobretudo dialógico, participativo, coletivo.

As três dimensões lazer, educação e saúde não dialogam entre si, de uma forma construída, sistematizada pela comunidade e poder pú- 
blico. 0 que se revela, na comunidade, é a apropriação e resignificação dos espaços pelos moradores transformando-os em espaços de lazer.

No bairro, há uma grande quantidade de terrenos baldios que são os principais pontos de vivência do lazer, principalmente nos finais de semana com os jogos de futebol e as brincadeiras das crianças (correr, soltar pipa ou brincar de bolinha de gude). Tais espaços não se configuram inseridos numa política pública, e apesar das reivindicações dos moradores, esses espaços poderiam ser urbanizados, com isso a experiência do lazer seria potencializada.

A extensa rede de canais coletores do bairro, mesmo em estado precário de conservação, comprometendo a relação entre lazer e saúde, é bastante utilizada pelos moradores que caminham e passeiam de bicicleta, é um ponto de encontro e local para momentos de descontração com conversas ou jogos de dominó e baralho. Nesse espaço, há uma interação entre os interesses culturais do lazer abordados por Dumazedier, mas como trata Marcellino (2008), ideal seria que nós tivéssemos vivências plurais com os diversos interesses, e não restringíssemos a uma especificidade de interesse, porém lembra o autor que isso se deve, na maioria das vezes, não por opção, mas por falta de contato, de conhecimento com outros conteúdos.

Os moradores deram sentido lúdico, prazer e tempo livre ao resignificarem o espaço do Mercado das Malvinas e o Giradouro (na entrada do bairro), as encostas de canais coletores, como sendo de lazer, deram o sentido do multifuncional a espaços que não foram projetados para esse fim. Com isso, entendemos que as políticas intersetoriais poderiam trabalhar para configurá-los numa melhor perspectiva para a experiência do lazer. Destaca-se, ainda, no bairro, a quantidade de casas de jogos eletrônicos e lanhouses, que advindas com o grande comércio existente nas Malvinas, são também fontes de ocupação dos moradores.

A condição de invasores desencadeada, na construção do bairro, persiste no cotidiano da comunidade revelando-se para alguns de maneira pejorativa para outros como identidade. Existe uma atmosfera que inspira o sentimento de pertencimento do bairro, sem com isso, querermos afirmar que seja uma comunidade homogênea desprovida 
de conflitos, de divergência, e ao mesmo tempo, sem querermos defender essa homogeneidade, afinal, a comunidade é plural. Porém, o sentido da palavra invasão transcende a conotação pejorativa, para nós, no caso das Malvinas, ela é poética porque cria a estética da comunidade em traçar e buscar formas de atender as suas necessidades urgentes e fundamentais para a vida digna, humana, considerando os interesses individuais e coletivos.

Acreditamos que os representantes, os moradores das Malvinas, de um modo geral, vivenciam de modo singular seu direito à moradia, lazer, saúde, segurança, educação, por isso reivindicam junto aos órgãos competentes, porém a força desta atitude precisa ser somada à política urbana, política de lazer, política cultural e demais setores da sociedade. É oportuno que a administração pública, principalmente, perceba o potencial de lazer existente no bairro, e ao mesmo tempo, as lacunas também existentes, principalmente, no que se refere aos espaços em condições limitadas de uso.

\section{Referências}

ALMEIDA, Marco Antonio Bettine de. Análise do desenvolvimento das práticas urbanas de lazer relacionadas a produção cultural no período nacional-desenvolvimentista à globalização através da "teoria da ação comunicativa". 2008. Tese (doutorado) UNICAMP - Faculdade de Educação Física. Campinas, SP, 2008.

BAHIA, Lilian Mourão. Rádios comunitárias: mobilização social e cidadania na reconfiguração da esfera pública. Belo Horizonte: Autêntica, 2008.

BAUMAN, Zygmunt. Comunidade: a busca por segurança no mundo atual. Rio de Janeiro: Jorge Zahar Ed., 2003.

BRUHNS, Heloisa Turini. Relações entre a educação física e o lazer. In: BRUHNS, H. T. (org). Introdução aos estudos do lazer. Campinas: Unicamp, 1997. 
CHEMIN, Beatris Francisca. Políticas públicas de lazer: o papel dos municípios na sua implementação. Curitiba: Juruá, 2008.

GASTAL, Susana. Imaginário urbano: relendo o texto praça. 2005. Disponível em: <http://www.bocc.uff.br/pag/gastal-susana-imaginariourbano-relento-texto-praca.pdf>. Acesso em: 12 mar 2009.

IBGE - Instituto Brasileiro de Geografia e Estatística. Censos Demográficos 1991/2000. 2002.

LIMA, Dália Maria Maia Cavalcanti de. O espaço de todos cada um no seu lugar: o uso dos espaços públicos destinados ao lazer em Natal. 2006. Tese (doutorado em Ciências Sociais) - PPGCS - UFRN, Natal, $R N, 2006$

MARCELLINO, Nelson Carvalho. Lazer e cultura: algumas aproximações. In: MARCELLINO, Nelson Carvalho (org). Lazer e cultura. Campinas: Alínea, 2007.

MARCELLINO, Nelson Carvalho; BARBOSA, Felipe Soligo; MARIANO, Stephanie Helena. Espaços e equipamentos de lazer: apontamentos para uma política pública. In: MARCELLINO, Nelson Carvalho (org). Políticas públicas de lazer. Campinas: Alínea, 2008.

MELO, Luis Gonzaga. Campina Grande o desenvolvimento em questão: seleção de artigos publicados na imprensa. Campina Grande: Gráfica Júlio Costa, 1988.

MIGUEL, Agnaldo; SILVA, Francinete. Especial Malvinas 24 anos de lutas e conquistas. Campina Grande, mar 2007. Encarte jornalístico realizado pela prefeitura de Campina Grande em comemoração ao aniversário das Malvinas.

MUNIC - Pesquisa de Esporte 2003. Coordenação de População e Indicadores Sociais. Rio de Janeiro: IBGE, 2006. 
NETO, Alfredo Feres; CASTRO, Maíra de Souza G. F. de. Um olhar sobre as relações entre as políticas públicas implementadas pelo Ministério da Cidade e o Lazer. In: SUASSUNA, Dulce; AZEVEDO, Aldo Antonio de (org.). Política e lazer: interfaces e perspectivas. Brasília: Thesaurus, 2007.

OLIVEIRA, Iaponira Sales de; SILVA, Mônica Maria Pereira da. Educação ambiental em comunidade eclesial de base na cidade de Campina Grande: contribuição para o processo de mobilização social. Revista Eletrônica de Mestrado em Educação Ambiental, v.18, janeiro a julho de 2007.

PALMA, Alexandre; ESTEVÃO, Adriana; BAGRICHEVSKY, Marcos. Considerações teóricas acerca das questões relacionadas à promoção da saúde. In: BAGRICHEVSKY, M.; PALMA, A.; ESTEVÃO, A. (orgs). A saúde em debate na educação física. Blumenau: Edibes, 2003.

PELLEGRIN, Ana de. Os contrastes do ambiente urbano: espaço vazio e espaço de lazer. 1999. Dissertação (mestrado) UNICAMP - Faculdade de Educação Física. Campinas, SP, 1999.

RECHIA, Simone. Parque públicos de Curitiba: a relação cidade-natureza nas experiências de lazer. 2003. Tese (doutorado) UNICAMP - Faculdade de Educação Física. Campinas, SP, 2003.

. 0 jogo do espaço e o espaço do jogo em escolas da cidade de Curitiba. Revista Brasileira de Ciências do Esporte, Campinas, v. 27, n. 2, p. 91-104, jan. 2006

ROSA, Maria Cristina. As festas e o lazer. In: MARCELLINO, Nelson Carvalho (Org.). Lazer e cultura.Campinas: Alínea, 2007.

SILVA, Débora Alice Machado da. Territórios do lazer: panoramas e reflexões sobre a animação sociocultural. In: MARCELLINO, Nelson Carvalho (org). Políticas públicas de lazer. Campinas: Alínea, 2008. 
SOUSA, Bernardete de Lourdes Queiroga e. A praça André de Albuquerque, Natal/RN, na visão de seus frequentadores. 2004. Dissertação (mestrado). Universidade Federal do Rio Grande do Norte. Centro de Ciências Humanas, Letras e Artes.Natal, 2004. Disponível em: <http:// bdtd.bczm.ufrn.br/tedesimplificado/tde_arquivos/1/TDE-2006-0519T000544Z-51/Publico/BernardeteLQS.pdf>. Acesso em: 07 mar 2009.

TORO, José Bernardo; WERNECK, Nisia Maria Duarte. Mobilização social: um modo de construir a democracia e a participação. 1. reimp. Belo Horizonte: Autêntica, 2007. 


\title{
Pelo direito ao lazer: participação e mobilização social no bairro de Santa Rosa
}

\author{
Luiz César Pereira de Mendonça \\ Emília Amélia Pinto Costa da Silva \\ Nayara Suênia de Oliveira \\ Eduardo Ribeiro Dantas
}

As políticas sociais brasileiras, dentre elas as do lazer, precisam ultrapassar a lógica paternalista e assistencialista que ainda vem caracterizando as administrações públicas do país. Principalmente em municípios como os do interior nordestino, onde traços de um Coronelismo arcaico insistem em compor a paisagem política local, comprometendo com isso, possíveis inovações e melhorias nas formas de gestão pública, tais como, a participação mais intensa dos atores sociais na construção da vida em comum.

Desse modo, acompanhariam a tendência apontada por Pinto (2008), para quem já podemos observar a existência de determinados processos políticos, no Brasil, construídos a partir de acordos e conflitos diários, que vividos no interior de relações sociais historicamente contextualizadas, agem na vida individual e coletiva da população, garantindo o princípio básico da política. Modelos estatais de gestão de recursos, que mesmo tendo em vista interesses diversos e contraditórios, característicos de uma sociedade democrática e plural, conseguem construir, a partir das mediações possíveis, movimentos positivos de interesse público. 
Para que isso ocorra de uma forma mais abrangente no cenário nacional, considerando-se especificamente as políticas públicas de esporte recreativo e de lazer, precisamos, antes de qualquer coisa, ampliar o debate sobre o que vem sendo compreendido como inovação no âmbito das políticas sociais e da gestão pública, sob o risco de, se assim não o fizermos, repetirmos com uma roupagem renovada, discursos e práticas administrativas malsucedidas, na já difícil tarefa de propiciar o direito ao lazer à população brasileira.

Segundo Pinto (2008), a discussão sobre a necessidade de inovação, no campo político, vem avançando nos debates que tratam das racionalidades aplicadas às gestões privada e pública, de uma forma em geral. Isso nos leva a perceber, num primeiro momento, que sua operacionalização não se limita ao campo do lazer, nem tampouco à esfera pública, por mais que tratemos especificamente dessas questões neste texto.

Para a autora, é preciso considerar que a inovação não significa necessariamente uma ruptura completa em relação a práticas políticas anteriores, podendo ocorrer em pequenos avanços e não ser caracterizada como totalmente original, mas como uma melhoria. Até porque, segundo ela, é muito difícil uma política inovar em relação a muitos aspectos (PINTO, 2008).

Há ainda o fato de que algumas mudanças, apesar de não serem novas do ponto de vista histórico da administração pública, podem ser encaradas pela população como uma inovação, o que, de acordo com a autora, revela a pluralidade de significados do termo e a importância do vivido dos atores sociais na sua determinação, resultando em novos olhares sobre os problemas enfrentados e sobre as alternativas construídas para sua solução (PINTO, 2008).

Discutindo o que mudaria no modo dominante de se fazer políticas sociais de lazer no Brasil, para que pudéssemos considerá-las inovadoras, a autora destaca a necessidade de privilegiarmos certos aspectos, já presentes em experiências emergentes no país (PINTO, 2008).

Um desses aspectos, a mudança na lógica centralizadora de tomada de decisões sobre a vida pública, interessa-nos particularmente neste momento, já que gera uma situação que no nosso entendimento 
é fundamental para o sucesso não só de políticas de esporte recreativo e de lazer, mas de qualquer outra política social promovida pelo Estado brasileiro.

Estamos falando da participação da própria população na elaboração e efetivação da ordem social desejável a todos. Participação esta, que de acordo com Toro e Werneck (2007), deve ser considerada a essência do modo de vida democrático, assim como também, uma necessidade para o desenvolvimento social.

E já que tocamos na questão do desenvolvimento social, potencializado pela participação popular nas decisões sobre a vida coletiva, não custa lembrarmos que através do lazer, essa condição pode ser alcançada ainda mais rápido, já que ele é um fenômeno que agrega não só possibilidades de descanso e divertimento, mas também, de desenvolvimento pessoal e social, além de se constituir um instrumento de mobilização e participação cultural (MARCELLINO, 2008).

É através dessa reflexão sobre o envolvimento do povo com as políticas públicas de esporte recreativo e de lazer, que passamos a discutir agora o cotidiano lúdico do Santa Rosa, na tentativa de fornecermos pistas sobre como podemos efetivar o direito ao lazer, constitucionalmente posto, a partir da participação e da mobilização dos atores sociais deste bairro.

Participação esta, que se não é intensa nos momentos de reivindicar melhorias ao poder público, apesar dessa prática vir aumentando no bairro, pode ser vista nas vivências coletivas de lazer da população, que revelam um ambiente propício à mobilização social no Santa Rosa.

\section{Descendo a Rua do Sol: um bairro em movimento}

Como a maioria dos bairros e pequenos municípios de um país predominantemente católico, o Santa Rosa, situado na cidade de Campina Grande - PB, guarda estreitas relações com a igreja local, Santa Rosa de Lima, localizada na Rua do Sol, uma das principais ruas do bairro.

Descendo a Rua do Sol em direção à referida igreja, deparamo-nos com um bairro em intensa agitação. São diversos pontos comerciais, 
como farmácias, padarias e bares, que juntamente a instituições como a Sociedade Amigos do Bairro - SAB Santa Rosa, a Escola Municipal Tiradentes e a Unidade Básica de Saúde Adriana Bezerra de Carvalho, atendem os moradores do bairro no seu cotidiano.

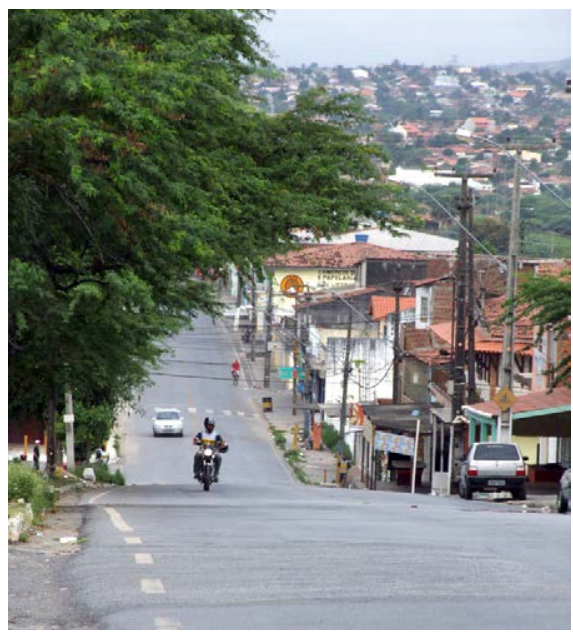

Imagem 01: Rua do Sol: coração do Santa Rosa Fonte: Arquivos do GCEM

Saindo do Quarenta, um dos limites do Santa Rosa, a Rua do Sol cruza o bairro até chegar ao Dinamérica, revelando em suas esquinas um povo hospitaleiro e acolhedor, que todas as vezes que foi solicitado, não se furtou a responder nossas questões.

De acordo com a lei municipal de divisão de bairros $\mathrm{n}^{0 .}$ 1.542/87, o Santa Rosa é limitado pelo Centenário, Cruzeiro, Santa Cruz e pelo Bodocongó, além do Quarenta e do Dinamérica, já mencionados. Mas é este último que guarda uma relação particular com o bairro, por ter sido um desmembramento do mesmo. Além disso, é onde hoje se situa o Complexo Esportivo e Educacional "O Meninão", que recebe em suas instalações e seus arredores, boa parte dos moradores dos bairros vizinhos. 


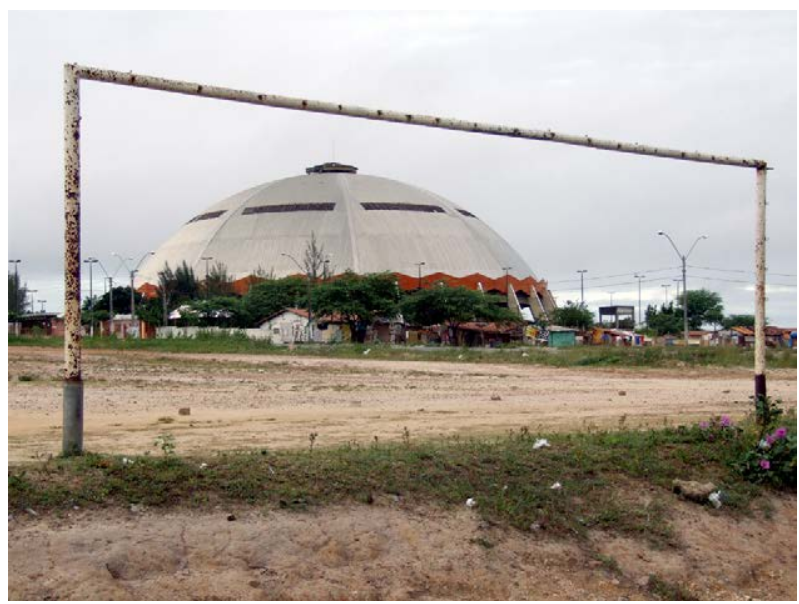

Imagem 02: "0 Meninão": opção de lazer para muitos bairros da cidade

Fonte: Arquivos do GCEM

Inclusive do Santa Rosa, como relata o presidente da SAB do bairro, um de nossos entrevistados, ao responder se havia algum campo de futebol na comunidade, para a prática dos diversos times locais.

Tem. É aí no Meninão. Mais por ali... tem vários campos... ali ao redor do Meninão, campo de pelada. $\mathrm{O} \mathrm{Me-}$ ninão... é no Dinamérica, é pertinho... Era Santa Rosa. É que depois criaram o Dinamérica, aí incluíram pra lá né? Mas ali tem vários campos de futebol... no domingo, várias gente lá jogando pelada (Presidente da SAB Santa Rosa).

Além dos times de futebol que jogam no descampado ao seu redor, “O Meninão" recebeu, no ano de 2008, as atividades do Programa Esporte e Lazer da Cidade - PELC, promovido pelo Ministério do Esporte.

Programa este que, através de parcerias locais, ofereceu atividades gratuitas como a dança, o voleibol, o judô, o futsal, a capoeira, dentre outras, sendo encerrado em março de 2009, em função do fim do convênio entre o Ministério do Esporte e o Serviço Social da Indústria - SESI/PB. 
É interessante notar, que o referido programa não foi citado pelo presidente da $\mathrm{SAB}$, quando questionado sobre as ofertas de lazer existentes para os moradores do bairro. 0 que nos leva a indagar se ele sabia da existência do mesmo, se esqueceu ou até mesmo se não quis mencionar, por questões político-partidárias, comuns no contexto investigado pela nossa pesquisa.

Ali na... na Avenida Dinamérica... sim tem "O Meninão". Mas "O Meninão" é uma coisa que é pra cidade inteira né? Não é exclusivo do Santa Rosa, e até o povo do Santa Rosa não tem direito de brincar lá... lá é cobrado também... essas coisas não usa de graça não (Presidente da SAB Santa Rosa).

Seja qual for o motivo que o levou a não mencionar o PELC enquanto possibilidade de lazer dos moradores do Santa Rosa, a situação ao nosso ver é preocupante, já que revela o não reconhecimento por parte de uma das lideranças mais atuantes do bairro, sobre uma das mais importantes políticas públicas setoriais de esporte e lazer que temos hoje no Brasil, que busca propiciar o direito ao lazer à população brasileira, através do princípio da gratuidade.

0 fato do presidente da SAB não ter mencionado as ações do PELC, porém, não quer dizer que os moradores do bairro deixaram de usufruir delas enquanto estiveram ativas, como pudemos perceber através da nossa observação de campo.

Queremos destacar, entretanto, que em se tratando da necessidade de participação do povo nas políticas públicas de esporte recreativo e de lazer, não só como beneficiários das ações promovidas pelo Estado, mas também como co-gestores das mesmas, precisamos de canais institucionais consolidados.

Canais como as Sociedades Amigos de Bairro que, através de gestores informados sobre o que ocorre não só em âmbito local, possam estar servindo de mediação entre o poder público e os desejos da população, colaborando, assim, com a constituição de políticas realmente participativas. 
As políticas participativas de acessibilidade associamse à construção de espaços políticos para negociação de interesses públicos e pactos sociais, envolvendo atores sociais e gestores de diferentes setores empenhados na conquista de direitos (PINTO, 2008, p. 65).

A visão do presidente da SAB sobre a impossibilidade de uso de um espaço público pelo povo do Santa Rosa reflete, por sua vez, um conceito de patrimônio público muito aceito nos países da América Latina.

Segundo Toro e Werneck (2007), enquanto a América do Norte foi formada por cidadãos que chegaram para viver e constituir a esfera pública, em países como o Brasil, o que chegou foi um conjunto de instituições em busca de riquezas para se explorar.

De forma que se perpetuou, no imaginário social do país, uma separação entre aquilo que seria propriedade do governo e aquilo que seria público. Os espaços públicos são vistos, desse modo, como espaços do governo e não do povo (TORO; WERNECK, 2007).

Entendemos que a atitude da Prefeitura Municipal de Campina Grande, que ainda hoje cobra da população taxas ditas simbólicas para a utilização do "Meninão", reforça essa compreensão, afastando do esporte recreativo e do lazer, aqueles que mais precisam do seu amparo institucional, como é o caso das pessoas que vivem em condições precárias de moradia, ao lado do próprio "Meninão".

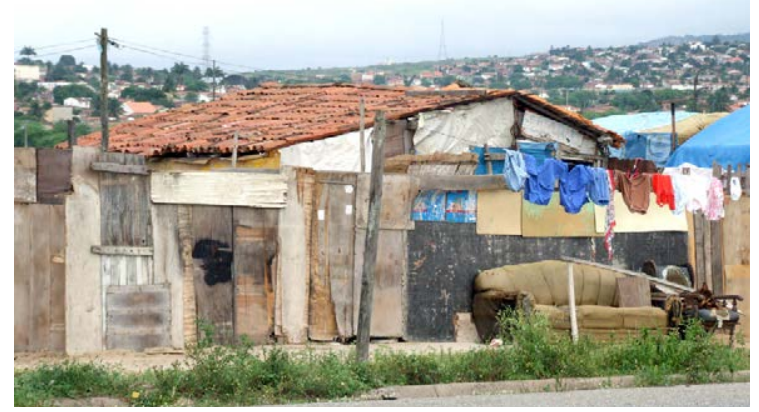

Imagem 03: Vizinhança do "Meninão": tão próxima e tão distante do lazer

Fonte: Arquivos do GCEM 
Compreendemos, ainda, que fazendo parte do setor social público e estatal, a administração do "Meninão" não deveria estar realizando nenhum tipo de cobrança à população, para dessa forma garantir a efetivação do direito ao lazer não só aos moradores do Santa Rosa, mas a todo o povo de Campina Grande.

Somente assim, através da gratuidade de suas políticas públicas setoriais de lazer, a Prefeitura Municipal de Campina Grande conseguirá atender uma parcela significativa da população, que já não tem acesso a direitos sociais básicos, como uma habitação digna ou uma escolarização adequada, tão urgentes quanto o esporte recreativo e o lazer.

Voltando ao discurso do nosso entrevistado, queremos frisar que, apesar de criticar a cobrança de taxas para que a comunidade do Santa Rosa tenha direito a brincar no "Meninão", o presidente da SAB considera normal e necessário o pagamento de colaborações e contribuições, também simbólicas, para que a comunidade do Santa Rosa tenha acesso às dependências da SAB.

Questionado sobre os pertencimentos do prédio da SAB, ele revela, através do seu depoimento, que a questão da cobrança pelo acesso ao espaço público, em Campina Grande, não é tão fácil de ser explicada quanto parece, alimentando, assim, o debate sobre as relações entre o público e o privado.

É (da SAB). Mas é um prédio que é público. É da SAB porque foi doado pra esta instituição... Foi feito pra $S A B$, agora não é particular não, a SAB não tem esse prédio como particular não, é público. Agora é um público que é da $S A B$, só quem resolve problema aqui são os diretores da SAB (Presidente da SAB Santa Rosa).

Não queremos com isso criticar a cobrança de taxas por parte da $\mathrm{SAB}$ aos seus sócios. Entendemos que a $\mathrm{SAB}$, regida por um estatuto e regimento próprios, constitui-se em pessoa jurídica de direito privado e, dessa forma, pode cobrar contribuições mensais dos seus associados.

Gostaríamos apenas de discutir um ponto que nos parece importante, em se tratando das funções sociais da SAB Santa Rosa. Sendo ela 
uma entidade civil, de caráter comunitário e popular, que de acordo com seu estatuto (UCES, 2009), tem como um dos objetivos a defesa dos interesses do povo, especialmente no tocante à luta pela implementação de políticas públicas de combate à pobreza, não pode jamais, deixar de ouvir e defender aqueles que representam, inclusive, os menos favorecidos.

Considerando o conjunto de moradores de um bairro, enquanto um grupo heterogêneo de pessoas que nem sempre possuem as mesmas condições de existência, a SAB Santa Rosa deve pensar em estratégias para que a cobrança de taxas não seja também, assim como no caso do "Meninão", motivo para que as pessoas se afastem ou sejam excluídas dela, o que deixaria sua representatividade de bairro limitada àqueles moradores que podem arcar com os encargos cobrados.

E nem todos, no Santa Rosa, possuem essa condição. Como o próprio gestor entrevistado nos diz, faz mais de dez anos que ele se depara com pessoas morando em condições precárias, na única praça do bairro, que fica situada às margens da linha do trem, perto da SAB. Fato este, que revela a existência de um bairro segmentado e economicamente desigual, onde os estratos sociais mais vulneráveis da população não têm como arcar com as taxas cobradas pela SAB, mesmo que elas sejam as menores possíveis.

Situação que faz da sustentabilidade financeira, um desafio para os gestores das Sociedades Amigos de Bairro da cidade de Campina Grande, que de uma forma em geral, sobrevivem mais da boa vontade de certos abnegados, do que propriamente de uma estrutura organizacional planificada e autosustentável.

Segundo o presidente da SAB Santa Rosa, ao explicar como lida com a falta de recursos financeiros, "a pessoa só come quando tem. Quando a gente não tem nada, a gente não gasta. Quando tem e chega alguma coisa, aí a gente vê "vamos fazer isso com esse dinheiro né?".

No nosso entendimento, essa realidade impede que as Sociedades Amigos de Bairro de Campina Grande, assim como outros grupos organizados da sociedade civil, dependentes de recursos oriundos da própria população para sua manutenção, possam constituir-se nos canais 
institucionais necessários à existência de políticas sociais de cunho participativo.

Outro ponto que nos chama atenção, quando analisamos o discurso do presidente da SAB Santa Rosa, é como a questão da identidade comunitária pode afetar a apropriação dos espaços públicos, por parte da população do bairro.

Ao lamentar que "O Meninão" não pertence ao Santa Rosa, por exemplo, mas sim à cidade inteira, o gestor deixa transparecer um certo sentimento de comunidade, ancorado na diferenciação entre "nós" e "eles", no qual podemos perceber o desconforto causado pela obrigação de compartilhar com moradores de outros bairros, algo não só "seu”.

Segundo Bauman (2003), um dos autores que discutem a questão da comunidade nas sociedades contemporâneas, ou melhor, a impossibilidade da existência de uma comunidade real nos dias atuais, a unidade de uma comunidade começa a encontrar dificuldades para sua sustentação, quando o fluxo de comunicação entre os "de dentro" e os "de fora" embaralha a distinção entre "nós" e "eles", impossibilitando a manutenção de fronteiras rígidas que evitem a perda da homogeneidade, ou seja, da mesmidade encontrada em uma comunidade ideal.

Este não é o caso do Santa Rosa. Pelo menos do Santa Rosa presente no discurso do gestor, que a partir da distinção do que deveria ser "nosso" e do que também é "dos outros", revela um certo senso de pertencimento à coletividade do bairro, cuja existência resulta em consequências diretas nas formas de organização da vida lúdica da comunidade.

Tanto em relação à apropriação dos espaços públicos pelos moradores do Santa Rosa, quanto à formulação e efetivação de políticas sociais que favoreçam a comunidade, já que, como discutimos anteriormente, consideramos que os gestores das Sociedades Amigos de Bairro possuem um papel fundamental na organização das localidades que representam, seja mediando a construção de políticas participativas, ou mesmo nas orientações cotidianas que dão à população. 
Na nossa visão, a compreensão de comunidade desses gestores é determinante para uma maior ou menor participação da população, não só no tocante às decisões tomadas sobre o bairro, mas até mesmo na vivência do esporte recreativo e do lazer. Pelo menos as vivências e decisões que dependem da estrutura das Sociedades Amigos de Bairro.

Um exemplo disso, é que, segundo o estatuto geral das Sociedades Amigos de Bairro de Campina Grande, para definição de quem pode participar de suas assembleias, cada SAB deve levar em conta os limites territoriais do bairro ou do conjunto que representa.

Apesar dessa determinação, pudemos perceber, através de nossa pesquisa, que alguns gestores entrevistados, em outros bairros de Campina Grande, não consideravam os limites dos mesmos enquanto parâmetro válido para inclusão ou exclusão de associados nas suas atividades, o que afasta, de imediato, o sentido de comunidade da questão territorial, mudando com isso, as possibilidades de participação da população nos processos decisórios do bairro em que vive.

Percebemos então, em relação à noção de comunidade, que muitas vezes a subjetividade dos atores sociais é mais determinante para a definição dos seus limites, do que propriamente o território que ocupa. Segundo Sennett (1999), um lugar se torna comunidade, quando as pessoas que o constituem utilizam o pronome "nós", partilhando crenças e valores em práticas diárias concretas.

No caso do Santa Rosa, pudemos notar que a população local considera como seus, os espaços e atividades realizadas no "Meninão", bem como, nos seus arredores. Isso porque, além da proximidade atual e da história que partilharam juntos, os moradores dos bairros do Santa Rosa e do Dinamérica, ainda hoje, são tratados pelo poder público de uma forma confusa, chegando a receber, por exemplo, correspondências entregues a uma mesma pessoa, a partir de endereços distintos.

Ao nosso ver, a discussão da noção de comunidade é fundamental para pensarmos não só em políticas participativas, mas também em possibilidades de mobilização social, já que esta ocorre quando "um grupo de pessoas, uma comunidade ou uma sociedade decide e age com um objetivo em comum, buscando, quotidianamente, resultados decididos e desejados por todos" (TORO; WERNECK, 2007, p. 13). 
Como falar em comunidade então? Ou mesmo em objetivos em comum e resultados desejados por todos, num bairro que, segundo o IBGE (2002), possui hoje mais de dez mil habitantes? 0 próprio presidente da $\mathrm{SAB}$, quando se refere a sua comunidade, às vezes, dá indícios de que está se referindo somente aos sócios da SAB Santa Rosa, enquanto em outros momentos, parece estar falando em nome de todos do bairro, o que nos mostra como a noção de comunidade também é escorregadia atualmente.

Ao justificar a necessidade de um agendamento prévio para a utilização dos espaços da SAB, o presidente nos diz que "antes aqui chegavam aquelas pessoas que não são bem vistas na comunidade, tomavam conta do horário dos outros, das pessoas de bem... mas de qualquer forma, essas pessoas têm vez... se marcá no horário deles, tá marcado".

Depoimento este, que nos mostra como dentro de um mesmo bairro, coexistem pessoas de diferentes condições sociais e propósitos junto à comunidade, de forma a se tornarem uma espécie de problema aos demais moradores. Ainda assim, o presidente da SAB Santa Rosa dá sinais que busca representar os moradores do bairro em sua totalidade, mesmo percebendo suas diferenças.

Neste sentido, conseguiu minimizar os conflitos entre os frequentadores das quadras da $\mathrm{SAB}^{1}$, reivindicou melhorias para os excluídos da praça Dr. Francisco Pinto, bem como, traçou estratégias mais suaves de cobrança das mensalidades, de forma a não afastar os moradores do bairro da instituição que representa.

Esses procedimentos negociados junto à população do Santa Rosa, favoreceram sua participação nas decisões sobre a vida coletiva da comunidade, a partir de uma instituição historicamente construída e mantida por seus moradores, como é o caso da SAB do bairro.

E que se continuar funcionando a partir da abnegação de poucos, corre o risco de desaparecer gradativamente, vítima de tempos em que

\footnotetext{
${ }^{1}$ Apesar de fazerem parte do centro comunitário do bairro, as duas quadras de cimento citadas nesse estudo, são administradas atualmente pela SAB local, o que, aliado ao fato das mesmas se situarem ao lado da SAB de Santa Rosa, sem que haja nenhum tipo de separação física, faz com elas sejam reconhecidas por parte da população como equipamentos específicos da SAB.
} 
um individualismo galopante concorre com a constituição de vínculos sociais mais profundos e duradouros.

Dessa forma, a participação democrática e coletiva da população é uma condição necessária não só para a elaboração e efetivação de políticas sociais mais atuantes no Santa Rosa, mas também, para a sobrevivência da sua própria SAB.

A seguir, vamos discutir como se dá efetivamente a participação popular no Santa Rosa, tendo em vista os limites e as possibilidades de constituição de políticas sociais participativas, a partir de uma maior atenção ao seu cotidiano lúdico.

\section{O cotidiano lúdico e a participação popular no Santa Rosa}

Discutindo a relação entre os conceitos de espaço e equipamento no campo do lazer, Marcellino, Barbosa e Mariano (2008), apontam para a existência de um certo entendimento, no qual o espaço é visto como o suporte do equipamento de lazer.

Por sua vez, o equipamento é compreendido como o objeto que organiza o espaço, em função da atividade que proporciona. Dessa forma, podemos ter atividades de lazer, sem equipamentos, mas não sem espaços disponíveis. Ainda de acordo com os autores, para democratizarmos o lazer, precisamos democratizar o espaço urbano (MARCELLINO; BARBOSA; MARIANO, 2008).

Dentro dos limites territoriais do bairro Santa Rosa, percebemos a falta de espaços públicos e equipamentos específicos para o lazer, que não estejam concentrados nas escolas públicas ou mesmo na SAB local, o que limita a experiência lúdica de sua comunidade, já que, como discutido anteriormente, esses locais possuem uma estrutura própria de organização e funcionamento.

No caso da $\mathrm{SAB}$, por exemplo, quem é sócio é que tem preferência na utilização de sua estrutura. 0 resto da população pode utilizar os seus espaços e equipamentos de lazer, desde que respeitada a prioridade dada aos associados da SAB. 
Agora, os sócios têm preferência né? Se uma pessoa que é sócio precisa da $S A B$, e uma pessoa que não é sócio precisa também, o sócio tem preferência, porque aqui é mais pelo sócio (Presidente da SAB santa Rosa).

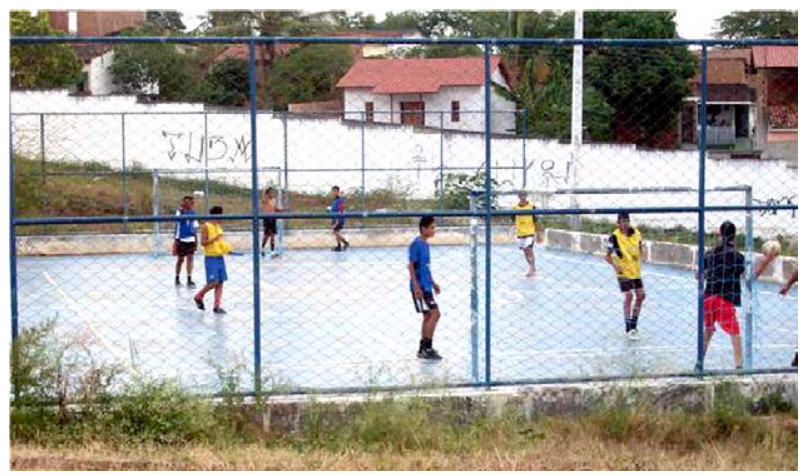

Imagem 04: Quadra da SAB Santa Rosa: regras específicas de utilização

Fonte: Arquivos do GCEM

Embora o bairro possua áreas que poderiam ser utilizadas para a construção de instalações favoráveis à prática do lazer, beneficiando os seus moradores, o que vemos, em linhas gerais, é a subutilização desses espaços.

Segundo Marcellino (1995), o espaço urbano tem sido bastante transformado, em virtude do crescimento das cidades, de modo que sua infraestrutura não atende às necessidades de lazer da população.

Dessa forma, observamos que, muitas vezes, os espaços existentes para o lazer não correspondem aos anseios da sociedade, como podemos notar no Santa Rosa, através do depoimento do presidente da SAB.

Espaços públicos, de lazer... é só esse daqui (da SAB). Usam outras escolas por aí, alguma coisa pra lazer... os grupos escolares, às vezes, quando a pessoa precisa pra um ensaio... alguma coisa... aí vão nas escolas, mas só no final de semana (Presidente da SAB Santa Rosa). 
O quadro seguinte mostra boa parte dos espaços e equipamentos específicos para a prática do esporte recreativo e do lazer, existentes no Santa Rosa, bem como, suas condições de uso pela população do bairro.

\begin{tabular}{|c|c|c|}
\hline Tipo & Quantidade & Condições de uso \\
\hline $\begin{array}{l}\text { Quadras da SAB } \\
\text { Santa Rosa }\end{array}$ & 2 & $\begin{array}{l}\text { De cimento, sem buracos e com postes de } \\
\text { iluminação }\end{array}$ \\
\hline $\begin{array}{l}\text { Quadra da SAB } \\
\text { Santa Rosa }\end{array}$ & 1 & De areia, ampla, limpa e nivelada \\
\hline $\begin{array}{l}\text { Parque infantil da SAB } \\
\text { Santa Rosa }\end{array}$ & 1 & $\begin{array}{c}\text { De alvenaria e madeira, feito em } \\
\text { área ampla e necessitando } \\
\text { de pequenos reparos }\end{array}$ \\
\hline $\begin{array}{l}\text { Salão de eventos da SAB } \\
\text { Santa Rosa }\end{array}$ & 1 & $\begin{array}{l}\text { De cimento, coberto e } \\
\text { sem mobília por perto }\end{array}$ \\
\hline $\begin{array}{l}\text { Campo de futebol da } \\
\text { Escola Municipal Tira- } \\
\text { dentes }\end{array}$ & 1 & $\begin{array}{c}\text { De grama, desnivelado e } \\
\text { necessitando de capinagem }\end{array}$ \\
\hline $\begin{array}{l}\text { Espaços livres da Escola } \\
\text { Municipal Tiradentes }\end{array}$ & - & $\begin{array}{l}\text { Geralmente de terra, desnivelados e neces- } \\
\text { sitando de capinagem }\end{array}$ \\
\hline $\begin{array}{c}\text { Salão da Escola } \\
\text { Municipal Tiradentes }\end{array}$ & 1 & $\begin{array}{l}\text { De cimento, coberto e } \\
\text { sem mobília por perto }\end{array}$ \\
\hline $\begin{array}{l}\text { Campos de futebol im- } \\
\text { provisados }\end{array}$ & - & $\begin{array}{l}\text { Geralmente de terra, com algum lixo e mato } \\
\text { por perto }\end{array}$ \\
\hline Ruas do bairro & - & $\begin{array}{c}\text { De asfalto ou paralelepípedos, com trânsito } \\
\text { de moderado a intenso }\end{array}$ \\
\hline
\end{tabular}

Quadro 1 - Espaços e equipamentos para o esporte recreativo e o lazer, existentes no bairro do Santa Rosa

Em se tratando dos espaços e equipamentos da SAB Santa Rosa, podemos perceber que se encontram em um bom estado de conservação, possibilitando sua utilização sem maiores problemas, por parte dos moradores do bairro.

Em relação aos espaços e equipamentos da Escola Municipal Tiradentes, outra instituição pública utilizada pelos moradores do Santa 
Rosa, podemos perceber, entretanto, que eles precisam de melhorias, no sentido de não colocarem em risco a integridade de seus usuários, na maioria crianças.

Compreendemos que a escola precisa sofrer uma intervenção do poder público que a administra, em relação à quantidade e qualidade dos espaços e equipamentos destinados ao seu cotidiano lúdico. Até mesmo porque, sabemos que, muitas vezes, a população, especialmente as crianças, não avalia os riscos da utilização de certos locais inapropriados para o uso, o que pode comprometer sua segurança e sua saúde.

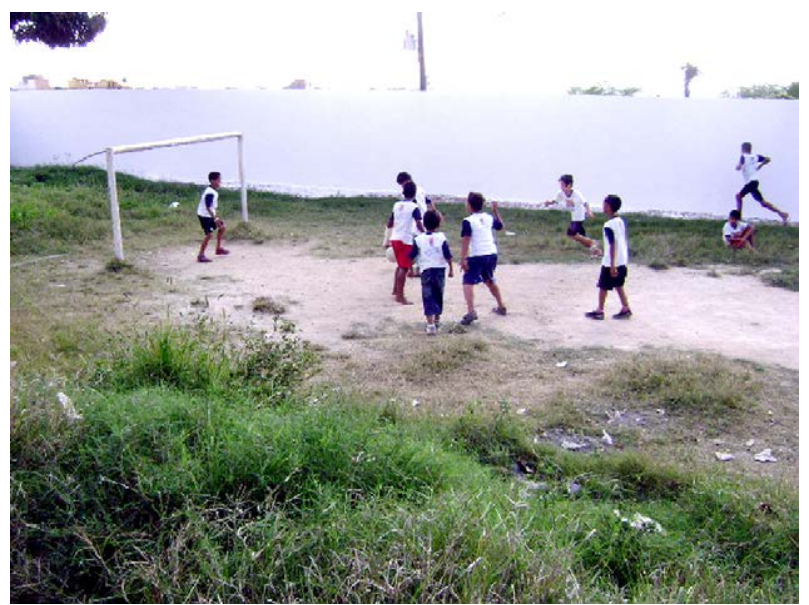

Imagem 05: Minicampo da Escola Tiradentes: futebol, mato e desníveis

Fonte: Arquivos do GCEM

Visitando a Escola Municipal Tiradentes, pudemos perceber como se dá a apropriação dos seus espaços por parte das crianças. Além das árvores que usam para subir e se balançar nos intervalos das aulas, elas brincam de jogos tradicionais, como a peteca, que se juntam às modalidades mais populares do esporte institucionalizado, tais como o futebol e o voleibol. 
Apesar de limitados, tanto em relação à quantidade, quanto às condições e possibilidades de uso pelos moradores do bairro, os espaços e equipamentos para o esporte recreativo e o lazer da SAB local e da Escola Municipal Tiradentes atendem boa parte da população do Santa Rosa, reduzindo a carência da comunidade nesse sentido.

Mesmo assim, apontamos a necessidade de maiores investimentos por parte do poder público, na infraestrutura voltada para o esporte recreativo e o lazer do bairro, tanto nos seus aspectos quantitativos, quanto qualitativos, já que como pudemos notar, os espaços utilizados fora da SAB Santa Rosa e da Escola Municipal Tiradentes, são os campos improvisados ou as ruas do bairro.

Precisamos alertar, porém, que o envolvimento da comunidade com o lazer não depende apenas da existência de mais ou melhores espaços e equipamentos construídos pelo poder público. A apropriação desses locais depende também dos interesses e da sensibilização da população para tanto, o que, em última análise, passa pela questão de uma educação para o lazer.

Um exemplo disso pode ser visto no Santa Rosa, pois os seus moradores vivenciam semanalmente as mesmas experiências de lazer, mesmo tendo outras possibilidades mais criativas. Segundo a diretora da Escola Municipal Tiradentes, outra gestora por nós entrevistada, os bares se constituem numa das principais opções de lazer dos jovens e adultos do bairro, principalmente nos finais de semana, após os "rachas" de futebol.

Prática comum não só no Santa Rosa, mas em todos os bairros de Campina Grande, o encontro com amigos, nos bares da cidade, é uma forma de estabelecer vínculos e laços sociais mais profundos com o local e as pessoas ao redor, preocupando-nos apenas, quando reduz a experiência do lazer da população, ao consumo excessivo de álcool, tornando-se, assim, uma questão de saúde pública.

E já que, de acordo com Stucchi (1997), a frequência da população, em determinados equipamentos, depende do local em que se encontram, compreendemos que os espaços e equipamentos públicos do Santa Rosa, construídos para a experiência do esporte recreativo e do lazer, deveriam não só ser ampliados e melhorados pelo poder público, 
mas também, melhor distribuídos na comunidade, beneficiando, assim, a população que não tem acesso à SAB e às escolas municipais.

Além disso, é importante atentarmos para a necessidade de intervenções, no bairro, que apresentem à população do Santa Rosa outras possibilidades existentes para o seu lazer, de forma a conscientizá-la sobre a importância do mesmo para o desenvolvimento do local e dos seus moradores.

Neste sentido, concordamos com Rechia (2008), para quem a luta em prol do lazer nada adianta, se os espaços destinados a ele resultam apenas em práticas relacionadas ao "mercolazer", ou seja, ao consumo desenfreado e alienante de serviços e mercadorias, relacionadas à indústria cultural.

Para a efetivação do direito ao lazer dos moradores do Santa Rosa, precisamos, então, da existência não só de políticas urbanas que, a partir das necessidades, desejos e participação da população, tratem da infraestrutura local. Precisamos também, na perspectiva intersetorial apontada por Chemin (2007), da união de políticas educacionais, culturais e de saúde, só para citar as mais importantes, em torno da problemática lúdica do bairro.

Bairro este rico em manifestações culturais, que são vividas cotidianamente pelos seus moradores, ou encontradas nos diversos eventos dos quais participam ao longo do ano, como podemos perceber no quadro a seguir. 


\begin{tabular}{|c|c|c|}
\hline $\begin{array}{l}\text { Manifestações culturais } \\
\text { e eventos }\end{array}$ & $\begin{array}{l}\text { Formas de } \\
\text { vivência }\end{array}$ & Temporalidade \\
\hline \multirow{4}{*}{ Futebol } & $\begin{array}{l}\text { Jogos recreativos } \\
\text { dos jovens }\end{array}$ & Diariamente \\
\hline & $\begin{array}{c}\text { Partidas entre os times } \\
\text { dos adultos }\end{array}$ & Finais de semana \\
\hline & $\begin{array}{l}\text { Campeonato entre os } \\
\text { times dos adultos }\end{array}$ & Uma vez por ano \\
\hline & $\begin{array}{l}\text { Jogos escolares } \\
\text { municipais }\end{array}$ & Uma vez por ano \\
\hline $\begin{array}{c}\text { Trava-línguas; “o que é o } \\
\text { que é”; lendas e mitos }\end{array}$ & Brincadeiras & Período escolar \\
\hline $\begin{array}{l}\text { Dia das mães, dos pais, dos } \\
\text { estudantes, da independência } \\
\text { e do fol clore }\end{array}$ & Festividades & Uma vez por ano \\
\hline Mostras culturais & Festividades & Eventualmente \\
\hline $\begin{array}{l}\text { Cabo de guerra; } \\
\text { dominó e damas }\end{array}$ & $\begin{array}{l}\text { Jogos escolares } \\
\text { municipais }\end{array}$ & Uma vez por ano \\
\hline $\begin{array}{l}\text { Pipa; peão; baleada; } \\
\text { "esconde-esconde"; } \\
\text { "toca-toca" e peteca }\end{array}$ & Brincadeiras & Diariamente \\
\hline \multirow{2}{*}{ Quadrilhas juninas } & Ensaios & Primeiro semestre do ano \\
\hline & Apresentações & Período junino \\
\hline \multirow{2}{*}{ Grupos de dança } & Ensaios & Semanalmente \\
\hline & Apresentações & Eventualmente \\
\hline Voleibol; capoeira; forró & $\begin{array}{l}\text { Jogos recreativos e } \\
\text { vivências lúdicas }\end{array}$ & Semanalmente \\
\hline Bingo & Festividade & Eventualmente \\
\hline Padroeira e "louvorsão" & $\begin{array}{l}\text { Festividades } \\
\text { religiosas }\end{array}$ & Eventualmente \\
\hline
\end{tabular}

Quadro 2 - Manifestações culturais e eventos existentes no bairro Santa Rosa 
Muitas vezes, porém, essas manifestações culturais acabam prejudicadas ou mesmo desaparecendo do bairro, em virtude da falta de apoio do poder público para sua realização. É o caso das quadrilhas do bairro e dos times de futebol, que apesar de possuírem uma trajetória de sucesso nas competições e eventos da cidade, sem incentivo, vêm tendo sua continuidade comprometida.

A atual diretora da Escola Municipal Tiradentes relata que a grande dificuldade na realização de ações por parte da escola, que venham contemplar a diversidade de manifestações culturais existentes, no bairro, é a falta de uma infraestrutura adequada e a inexistência de pessoas que se disponibilizem para a execução de novos projetos.

Compreendemos que a cidade de Campina Grande necessita de políticas públicas definidas para o lazer, sejam elas setoriais ou não, que se traduzam em projetos específicos para os seus bairros, contemplando tanto a questão da infraestrutura, quanto dos recursos humanos necessários a sua implantação.

Em se tratando de projetos sociais de lazer existentes no Santa Rosa, viabilizados pelo poder público, um rápido olhar para o bairro nos diz que a situação ainda está longe da ideal. Apesar da existência de projetos envolvendo o esporte, vinculados ao Programa de Erradicação do Trabalho Infantil - PETI, a demanda da população por esporte recreativo e lazer, gratuito e de qualidade, ainda é muito maior do que o poder público pode oferecer.

Enquanto a ajuda não vem, uma saída para as instituições do bairro, como a SAB e as escolas públicas, são as parcerias. A Escola Municipal Tiradentes, por exemplo, tem como parceiros, o sistema 4S e o Instituto Alpargatas, que através do projeto "Educação por Meio do Esporte", viabilizam materiais diversos para a prática esportiva.

Já a SAB Santa Rosa tem ou já teve, como parceiros, a Organização Não-Governamental Direito de ser Cidadão, o Clube de Mães do bairro, a Escola Municipal Tiradentes, a Secretaria de Educação do município, além de associações esportivas e moradores do bairro.

Compreendemos que o direito ao lazer não deve ficar na dependência dessas parcerias, mas sabemos, também, que hoje em dia, elas 
são fundamentais para a experiência do esporte recreativo e do lazer no Santa Rosa, já que por meio de incentivos, trocas e ajuda mútua, permitem que as instituições locais continuem a desenvolver suas atividades.

No Santa Rosa, quando em razão das disputas político-partidárias, elas não ocorrem, tudo se torna mais difícil, tanto do ponto de vista da gestão pública, quanto da apropriação do lazer pela população.

Mas para que os projetos cheguem ao bairro e as parcerias aconteçam, precisamos da participação da população. Voltamos então, ao ponto central da nossa discussão, tendo em vista a realidade do Santa Rosa.

Em linhas gerais, o envolvimento da população do Santa Rosa na co-participação das políticas públicas que a interessam, ainda é insuficiente. Principalmente se considerarmos as reivindicações relacionadas ao lazer.

A SAB do bairro, por exemplo, que atualmente possui cerca de 300 associados, o que por si só é um número inexpressivo frente à quantidade de moradores do Santa Rosa, reúne em suas assembleias mensais, quando muito, cerca de 30 a 50 sócios. 0 que segundo seu presidente, é uma conquista, já que quando assumiu o cargo, não havia nem as reuniões mensais.

Outro ponto problemático, em relação ao envolvimento da população do bairro na deliberação dos seus problemas, é relativo ao Orçamento Participativo da cidade. Segundo o presidente da SAB, apesar de ser um canal pelo qual as reivindicações do bairro já foram atendidas, as reuniões do Orçamento Participativo não contam atualmente com membros da direção da SAB.

Prova que a participação das pessoas é deficitária no bairro, é que, segundo o presidente da $\mathrm{SAB}$, ele só se candidatou ao cargo na primeira vez em que concorreu, para não deixá-lo vago. De acordo com o gestor, muitas pessoas que compõem a diretoria da SAB, hoje em dia, não honram com seus compromissos, participando apenas "de nome".

É interessante notar que a participação da população, na SAB, aumentou quando as condições melhoraram. Na primeira gestão do atual 
presidente, não houve concorrência. Já na eleição seguinte, após algumas melhorias alcançadas, já foram inscritas duas chapas concorrentes, de modo que houve necessidade até de uma campanha eleitoral ${ }^{2}$.

Sócio tem... na eleição passada, como concorreu duas chapas, aí houve mais... Foi feito bastante sócio, em base 900 sócios, mas foi sócio só pra votar... A gente... foi preciso ir atrás de pessoas pra fazer sócio pra votar. Não é aquele sócio que a gente faz pra participar né? Mas atualmente tem 300 a 300 e poucos sócios... Mas participante mesmo, se der 50 dá muito (Presidente da SAB Santa Rosa).

Consideramos importante que os sócios não sejam feitos apenas "para votar", mas que participem efetivamente junto à SAB e ao poder público, na elaboração de políticas públicas de lazer, informando as principais providências que precisam ser tomadas, para que a comunidade, de uma forma em geral, tenha acesso a esse direito básico de todo cidadão.

Para atender às demandas da população, torna-se necessário um diálogo da mesma com os poderes públicos, permitindo a participação popular na formulação das políticas sociais, pois, dessa forma, a comunidade poderá também apontar os caminhos a serem tomados.

Nesse processo de mobilização social pelo lazer, onde a participação da população tem grande relevância, um dos principais problemas a ser evitado é o pessimismo. Segundo Toro e Werneck (2007), uma das maiores barreiras ao processo de mobilização social é o costume com a ruindade, ou seja, o sentimento de que as coisas sempre foram assim e que não podem mudar.

Costume esse, que por pouco não fez o atual gestor da SAB desistir do cargo. Segundo ele, "quando eu entrei aqui muita gente disse "não vai passar três meses" né? E já vi fazer seis anos". Para o presidente, o pessimismo das pessoas é um dos principais problemas que enfrenta.

2 Na última eleição para presidente da SAB Santa Rosa, após a finalização da nossa pesquisa de campo, soubemos que foram inscritas três chapas. A disputa fez com que houvesse um debate para apresentação das propostas dos concorrentes, o que reforça o nosso argumento do aumento da participação popular, quando as condições existentes começam a melhorar. 
Dificuldades são muitas, mas eu acho que a maior dificuldade é as pessoas não poder ter assim... credibilidade das coisas que tá fazendo ...é muito difícil de organizar as pessoas. $O$ ser humano é muito difícil. Se fosse um bocado de ovelha, era bem mais fácil, só era tanger assim, levava... mas gente! Às vezes você está fazendo uma coisa para aquela pessoa e ela mesmo contra, contra aquilo que tá fazendo, que pode ser bom para ela, então atrapalha o que a gente tá fazendo para ela própria, ... É porque as pessoas só querem pegar o trem andando né, não pega o trem parado (Presidente da SAB Santa Rosa)

Para que a comunidade do Santa Rosa participe junto com o poder público na formação de políticas sociais efetivas, dentre elas as do lazer, é preciso que rompa com esse pessimismo orgânico e passe a apoiar as instituições que ainda podem servir de canais de participação popular. Só assim conseguirá inovar, de baixo para cima, a gestão pública do lazer em sua cidade.

\section{Considerações finais}

Após termos apresentado e discutido alguns aspectos do cotidiano lúdico do Santa Rosa, que não esgotam a reflexão ou têm a pretensão de corresponder à realidade definitiva do bairro, já que sabemos que a dinâmica social dessas comunidades é muito mais complexa do que as considerações que podemos fazer a seu respeito, principalmente se considerarmos sua grande extensão territorial e simbólica, gostaríamos de tecer alguns considerações mais pontuais, sobre as possibilidades de inovação na gestão pública do esporte recreativo e do lazer, tendo em vista a participação popular no bairro do Santa Rosa.

Em primeiro lugar, vamos tentar resumir os principais problemas do bairro, que no nosso entendimento atrapalham a possibilidade de efetivação do direito ao lazer para a população do Santa Rosa. Em seguida, tentaremos pontuar as condições de avanço que o bairro apresenta. 
Em relação aos espaços públicos e equipamentos de lazer do Santa Rosa, percebemos sua escassez ou centralização na SAB local e nas escolas públicas, o que de todo modo provoca a necessidade de deslocamento da população, para outros bairros da cidade.

Quanto às manifestações culturais e os eventos que as dão suporte, percebemos a predominância do futebol no bairro, que é vivenciado principalmente nos finais de semana, sendo seguido do consumo de bebidas alcoólicas.

Já quanto à participação da população na vida diária do bairro, pudemos perceber que ela só é grande, no momento de vivenciar as experiências de lazer. Quando chamados a deliberar sobre os problemas do bairro, a população praticamente some.

Os canais institucionais que servem de diálogo com o poder público estão praticamente sucateados, e a política-partidária ainda dá o ar da graça, influenciando negativamente o estabelecimento de parcerias locais, como no caso da relação problemática entre a SAB Santa Rosa e o Clube de Mães local, antes da gestão do atual presidente.

Finalmente, a questão da associação comunitária apenas para "fazer número" nos momentos que antecedem as eleições da SAB, preocupounos muito mais do que qualquer aspecto citado anteriormente, já que revela um entendimento viciado da participação popular na política pública, atrelado à visão do cidadão apenas enquanto um mero eleitor, cuja participação democrática nos processos que lhe dizem respeito, resume-se a um único dia em alguns anos.

Em contrapartida, seus espaços e equipamentos de lazer são melhores do que os vistos em muitos bairros de nossa pesquisa, além de contarem com a proximidade do "Meninão", o que de certa forma atenua a necessidade de grandes deslocamentos. As manifestações culturais são ricas e intensas, como as quadrilhas juninas existentes, não se limitando aos "rachas" de futebol nem muito menos ao consumo de álcool.

A participação da população não é a ideal, mas além de acontecer efetivamente nas vivências coletivas de lazer e nas reuniões de pais e mestres da Escola Municipal Tiradentes, por exemplo, cresce a par- 
tir do momento que a organização das instituições representativas do bairro, como a SAB Santa Rosa, aumenta, o que revela um ambiente propício à mobilização social dos seus moradores.

Para finalizar o presente artigo, apontamos um elemento interessante, que se levado em conta pode facilitar e muito a participação da população do Santa Rosa, nos processos que envolvem a elaboração e efetivação de políticas sociais necessárias ao bairro.

Estamos falando da organização da SAB e de outros canais institucionais do bairro, como a Escola Municipal Tiradentes, que próximos geograficamente, podem ser o instrumento que facilite a elaboração e execução de políticas públicas participativas de esporte recreativo e de lazer, usufruídas pelos moradores do bairro Santa Rosa.

Ao observamos suas atuais parcerias e seu histórico de reivindicações atendidas pelo poder público, além da crescente participação da população em sua estrutura, se bem cuidadas, podem ser decisivas para a elaboração e efetivação de políticas participativas no Santa Rosa, de forma que julgamos necessário, primeiramente, um olhar mais cuidadoso do poder público com essas instituições, antes de pensar em despejar ações verticalizadas no cotidiano lúdico do bairro.

\section{Referências}

CHEMIN, B. F. Políticas públicas de lazer: o papel dos municípios na sua implementação. Curitiba: Juruá, 2007.

IBGE - Instituto Brasileiro de Geografia e Estatística. Censos Demográficos 1991/2000. 2002.

MARCELLINO, N. C. Lazer e humanização. Campinas: Papirus, 1995.

. Subsídios para uma política de lazer: o papel da administração municipal. In: MARCELLINO, N. C. (Org.). Políticas públicas de lazer. Campinas: Alínea, 2008. 
MARCELLINO, N. C.; BARBOSA, F. S.; MARIANO, S. H. Espaços e equipamentos de lazer: apontamentos para uma política pública. In: MARCELLINO, N. C. (Org.). Políticas públicas de lazer. Campinas: Alínea, 2008.

PINTO, L. M. S. M. Estado e sociedade na construção de inovações nas políticas públicas sociais de lazer no Brasil. In: MARCELLINO, N. C. (Org.). Políticas públicas de lazer. Campinas: Alínea, 2008.

RECHIA, S. A Política de Lazer na Cidade: Em Pauta: "A Análise da Gestão dos Espaços em Distintas Realidades e Segmentos Populacionais. Encontro Nacional de Recreação e Lazer, 20., 2008, São Paulo. Anais... São Paulo, 2008. CD-ROM.

STUCCHI, S. Espaços e equipamentos de recreação e lazer. In: BRUHNS, H. T. Introdução aos estudos do lazer. Campinas: Unicamp, 1997.

TORO, J. B.; WERNECK, N. M. D. Mobilização Social: Um modo de construir a democracia e a participação. Belo Horizonte: Autêntica, 2007.

UNIÃO CAMPINENSE DAS EQUIPES SOCIAIS. Estatuto. Campina Grande, 2006. Disponível em: <http://www.ucescg.com.br/estatutos.html> Acesso em: 14 abr 2009. 


\title{
Estabelecendo relações entre as práticas e condições de lazer no bairro Jardim Borborema
}

\author{
Heluan Ruana Alves de Medeiros \\ Cheng Hsin Nery Chao
}

Ao propor uma abordagem voltada para o lazer no bairro Jardim Borborema, zona sul da cidade, buscamos conhecer e analisar o mesmo, estabelecendo as relações entre o lazer, saúde e educação, através de suas organizações, espaços, equipamentos e manifestações culturais.

O bairro possui uma singularidade que o diferencia em termos de características físicas, pois possui áreas urbanizadas, áreas rurais e ainda, áreas mistas: urbano/rural. Não se podendo generalizar as análises dos espaços de lazer como se fossem todos iguais.

Conforme Freitag (2006), devido à população não está tão atenta e ativa na exigência de seus direitos, o poder público acaba fazendo vistas grossas e perpetuando momentos em que a cidade passa a ser local de verdadeira barbárie, não havendo investimento nestas necessidades em muitos bairros. No caso do Jardim Borborema, percebemos que os representantes de bairro procuram garantir os direitos da população, porém é um processo lento que necessita vencer os caminhos burocráticos que se estendem ao longo dos anos.

A elaboração de políticas públicas de lazer pode ocorrer cada vez mais de modo interdisciplinar. Apesar de existirem questionamentos sobre o porquê do lazer sempre estar relacionado a outro fator, Leila Pinto (2008, p. 4) explica que 
A convergência de esforços, as alianças estratégicas, as redes de ações intersetoriais, compartilhadas, são essenciais para potencializarmos resultados significativos no sentido deste pacto estabelecido. No campo do lazer essa aliança é essencial, pois as ações do lazer não apenas podem potencializar a sua conquista como direito, como podem também contribuir efetivamente para a conquista de outros direitos, como saúde, educação, cultura, preservação ambiental, turismo, convivência com segurança, dentre outros.

Através dos direitos fundamentais de todo cidadão citados acima, atingem-se as funções sociais e bem-estar, que estão estreitamente ligados ao desenvolvimento humano e transformação social.

\section{Jardim Borborema: conquistas e relações, lazer, saúde e infraestrutura}

O Jardim Borborema é um bairro localizado na zona sul da cidade de Campina Grande com 3.883 habitantes (IBGE, 2002). Tem como bairros vizinhos: o Cruzeiro e Presidente Médici(N); Distrito Industrial (L), Acácio Figueredo (0). Os conjuntos Ressurreição e Jardim Vitória compõem esta comunidade.

0 bairro faz parte da periferia de Campina Grande, sendo marcado pela criminalidade, falta de infraestrutura e saneamento básico. Marcellino (2008, p.15) diz que o aumento da população urbana não foi acompanhado pelo desenvolvimento da infraestrutura, "gerando desníveis na ocupação do solo e diferenciando marcadamente, de um lado as áreas centrais, concentradoras de benefícios. E de outro a periferia, verdadeiro depósito de habitações".

Isso é o que ocorre na zona urbano/rural do Jardim Borborema, é um "depósito de habitações". Não identifica-se em todo bairro uma praça pública sequer, não há quadras esportivas de livre acesso ou qualquer outra área pública definida para o convívio social, fora a SAB e o calçadão da Avenida Juscelino Kubitschek que atravessa o bairro. 
Não se sabe muito sobre sua história, moradores com mais de 15 anos, no bairro, relatam que, há cerca de duas décadas, noventa e duas (92) casas foram cedidas para o mesmo número de famílias. Estas haviam perdido suas casas numa enchente e foram abrigadas no Estádio de Futebol da cidade, Governador Ernani Sátiro (0 Amigão), até a entrega de suas novas casas pela Prefeitura. Parte do conjunto Ressurreição foi ocupado por alguns garis da prefeitura que se inscreveram para concorrer e foram sorteados. Os ganhadores receberam o terreno e cada um se responsabilizou pela construção de sua casa.

A ex-presidente da associação de moradores, do conjunto Ressurreição mais especificamente, e moradora do bairro, passou-nos uma história de luta em comunidade para erguer a igreja. A doação do terreno foi o pontapé inicial para a construção, que fica no conjunto Ressurreição. Todo o restante da população contribuiu como pôde. Os mercadinhos próximos ajudavam e eram realizadas várias atividades para angariar fundos para a construção da Igreja.

Era realizado um verdadeiro mutirão. Segundo Gabriel (2008, p.65), “a modernidade, de fato, é caracterizada por uma redução da capacidade festiva, pela privação de certos hábitos coletivos de celebração e a progressiva individualização de alguns aspectos da vida em detrimento do coletivo", no entanto a comunidade Jardim Borborema mantém sua tradição cultural religiosa ativa.

O bairro possui várias igrejas que funcionam como canais institucionais do bairro. Cada qual com seus princípios tem influência nas ações de envolvimento e desenvolvimento da comunidade. É por meio de suas festas tradicionais que as comunidades estreitam seus laços e mantêm sua identidade como grupo, celebrando também sua vida cotidiana.

A grande maioria destas manifestações culturais religiosas proporciona o lazer. São atividades como bingos, feiras de roupa, festival de sorvete, serestas, feijoadas, rifas, São João, além da festa do padroeiro realizada em abril com a novena e três dias de comemoração com shows e comidas típicas.

A Associação de Moradores tem outras histórias de luta junto à comunidade. Conseguiu levar um Posto de Saúde da Família, iluminação, 
calçamento (em algumas ruas), saneamento básico na parte urbana do bairro, alfabetização para adultos além de vários cursos profissionalizantes para a comunidade.

Cada vez mais o Bairro cresce com ajuda da população através de associações representativas, como SAB e Associação de Moradores, que são bastante atuantes, objetivando sempre o atendimento às reivindicações dos moradores através de seus representantes. "Os moradores organizados vão se reconhecendo enquanto sujeitos sociais, capazes de projetar autonomamente suas práticas, processo que é contínuo, inacabado, diante das incessantes forças que tensionam para formas mais heterônomas de relações sociais" (MÜLLER, 1992).

A população sente a falta de políticas públicas de lazer e reclama que se houvesse incentivo neste sentido não haveria tanta droga e criminalidade no bairro. "O Lazer ocuparia o tempo em que estão aprontando das suas", fala um morador triste com a realidade.

Quanto à saúde, muitos associam ao lazer, primeiro por boa parte praticá-lo através de atividade física, segundo por trazer a sensação de bem-estar. Lamenta-se a falta de saneamento básico, infraestrutura, que faz com que crianças realizem suas atividades de lazer, seu brincar, em espaços com esgoto à céu aberto e junto dos animais que se encontram soltos no bairro.

A barbárie apontada no início do texto, baseando-nos em Freitag (2006), diz respeito justamente à falta de áreas públicas de lazer. As crianças que querem jogar bola têm que dividir o espaço com jumentos, bois, cavalos, a ponto de muitas já apresentarem carrapatos em suas roupas, como relata a assistente social responsável pelo Pro-Jovem Adolescente no bairro. 


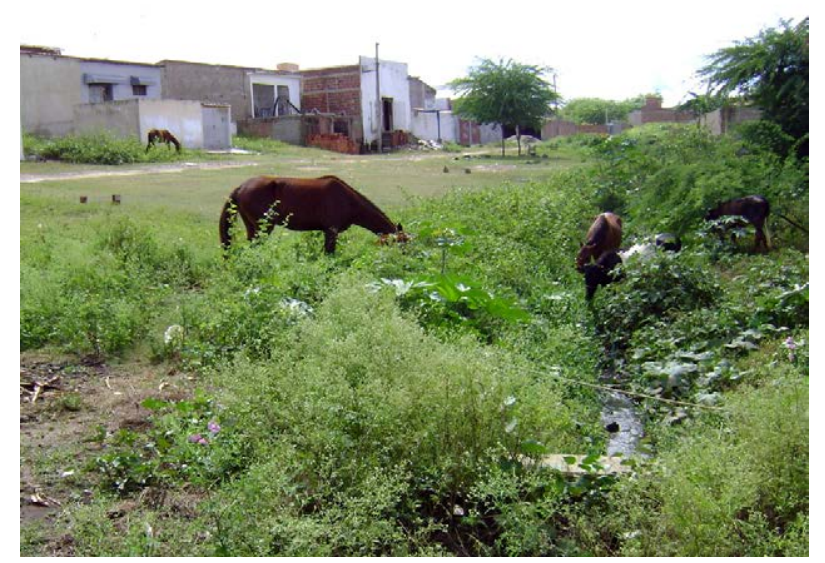

Imagem 01: Espaço utilizado por crianças para brincar

Fonte: Arquivo GCEM

A Unidade Básica de Saúde da Família, quando os pesquisadores foram a campo estava passando por reforma e funcionando temporariamente em uma sala da SAB. O PSF tem sua participação no lazer da comunidade, como coloca Yara Carvalho (2008, p.113):

\begin{abstract}
O lazer pode ter na atenção básica e no PSF um espaço interessante para compor com o cuidado e a atenção em saúde. O espaço e o tempo do lazer podem ampliar as possibilidades de encontrar, escutar, observar e mobilizar as pessoas adoecidas para que no processo de cuidar do corpo elas efetivamente construam relações de vínculo, de co-responsabilidade, autônomas, inovadoras e socialmente inclusivas(...).
\end{abstract}

Numa relação mútua de benefícios entre saúde e lazer, vê-se a necessidade de uma maior atuação do PSF junto à comunidade, já que esta deve "valorizar e otimizar o uso dos espaços públicos de convivência e de produção de saúde" (CARVALHO, 2008, p.113).

A Unidade Básica de Saúde da Família do bairro disponibiliza o espaço fora do horário de expediente para as reuniões do Clube de Mães, que ainda não tem sede. Durante a pesquisa de campo, como o PSF esta- 
va em reforma, as reuniões do clube de mães estavam sendo realizadas num pequeno terraço em frente da casa da presidente.

\section{A organização da comunidade gera força nas reivindicações e ações sociais}

A SAB foi fundada em 1986, o atual presidente já está na liderança, há sete anos, eleito e reeleito após a morte do fundador. Junto à presidência estão mais dez sócios na gestão, entre eles o vice-presidente, secretários, tesoureiros e cinco pessoas da fiscalização. A SAB conta com a contribuição mensal na quantia de dois reais $(\mathrm{R} \$ 2,00)$ de cerca de 600 sócios e os próprios moradores se envolvem com o trabalho voluntário nas atividades da sociedade.

Quando se fala em parcerias é com grande satisfação que o presidente fala do crescimento nos diversos aspectos, inclusive na questão visual da unidade com a pintura, mas afirma que:

a maior preocupação nossa aqui, era de capacitar as pessoas para o mercado de trabalho, certo? E aí fizemos uma parceria primeiro, primeiro com o Governo do Estado na reforma, em seguida parceria com o SENDAC, que eles têm vários cursos profissionalizantes para os jovens, para mulher, pra o adulto, qualquer pessoa que queira fazer acima de 16 anos. Em seguida nós fizemos parceria também com o SENAC, SENAI e a FINEP, também que pertence ao Governo do Estado. E agora nós estamos fechando um acordo entre SENAC e Redentorista, e também como, fiz também aqui com uma parceria com a UEPB que foi o ambulatório itinerante que o ano passado tivemos duas vezes aqui.

Na fala acima, podemos notar a busca por várias parcerias, isso pode mostrar a pouca atenção e destinação de verbas pelo poder público e desta forma, a necessidade por diferentes fontes de renda.

A SAB é uma conquista do bairro assim como também trouxe benfeitorias para o mesmo, como lembra o presidente que "conseguiu através da SAB muitas coisas, muitos benefícios, principalmente a ener- 
gia que não tinham... É luz, água, transporte, tudo foi uma luta muito grande".

"A participação cidadã não deve ser encarada pelos governantes como uma concessão, mas um direito do cidadão"(MARCELLINO, 2001). Esta afirmação implica na co-gestão entre organizações comunitárias e o poder público, onde a iniciativa da população e o financiamento do governo integrados trarão o resultado final.

A Sociedade Amigos do Bairro (SAB), Associação de Moradores e Clubes de Mães são parte da representatividade de uma comunidade através da qual é possível através de reuniões e assembleias discutir o que é melhor para o bairro, para assim, identificar soluções e reivindicar ao poder público. Como na SAB do Jardim Borborema uma vez por mês realiza:

a assembléia geral onde convidamos todos os moradores, sócios ou não, para participar. (...) A gente tem um papel muito importante, principalmente, como se diz, em orçamento participativo, a SAB tem por direito de participar do orçamento para que traga os benefícios para nossa comunidade (Presidente da SAB)

Apesar de comentar sobre as necessidades relacionadas ao lazer, percebe-se uma maior facilidade em oferecer capacitação profissional aos moradores do bairro. E fala que tem como principal função, a social:

Integrar as pessoas à comunidade, juntar e criar pontes para criar reivindicações, principalmente na área de lazer que nós não temos, é cultura também que infelizmente nosso povo é muito atrasado, também com o profissionalismo. (Presidente da SAB)

Junto às parcerias ofereceram cursos de confecção de calçados, recepcionista, corte e escova, corte e costura, macramê, crochê, pintura em tecidos, de doces e salgados e curso de favo de mel, este último com recursos próprios. Cursando e praticando o que aprendem, estas pessoas, que, na maioria, são as donas de casa, sentem-se mais úteis para os outros e acima de tudo para si mesmas, visto que fazer, ou pelo menos deveriam fazer, por livre e espontânea vontade podendo 
ser considerado um momento de lazer, por oferecer um momento de socialização, aprendizado, criatividade e produtividade.

É visto um trabalho sério e dedicado por parte dos gestores para ajudar a comunidade, lamenta-se o fato de não enviarem projeto por não saber redigir um. 0 presidente e seu vice afirmam já ter enviado oficio solicitando algum curso e expondo as ideias à prefeitura. 0 mais interessante foi a espera de um treinamento em gestão a ser oferecido pela Universidade Federal de Campina Grande - UFCG. Com isso poderiam pôr as ideias em um projeto bem estruturado e enviar aos poderes públicos.

No âmbito do lazer, pensam mais na questão de uma área que possa oferecer práticas físicas, neste almejam um lugar onde os moradores pudessem praticar a natação, o vôlei, o futebol. Também desejam uma sala de informática, na qual possam oferecer o curso.

Segundo a presidente do Clube de Mães, algumas áreas já foram definidas pela prefeitura há algum tempo, contudo, o interesse político tem trazido barreiras para a edificação destes locais. Ainda percebe-se a questão político partidária-influindo nas conquistas dos direitos dos moradores, pois os líderes comunitários, muitas vezes, precisam se tornar verdadeiros cabos eleitorais para ter suas reivindicações atendidas, caso seu candidato ganhe.

\section{A Escola: as parcerias precisam caminhar juntas}

Das 88 escolas da rede municipal de ensino encontradas na zona urbana da cidade, três (03) se encontram no bairro em estudo. A escola onde foi realizada a pesquisa trata-se de um Centro Educacional de Atividades Integradas - CEAI Antônio Marques da Silva Mariz, fundado em 1995. A escola tem parceria com o Instituto Alpargatas ${ }^{1}$ no Projeto de Educação por Meio do Esporte.

10 Instituto Alpargatas investe na capacitação continuada dos profissionais da Educação, promove concursos de instrumentos didático-pedagógicos para tornar as aulas mais atrativas e fornece às escolas os recursos e equipamentos necessários à aplicação dos projetos (Instituto Alpagatas). 
Com esta parceria, a escola reduz o custo com os equipamentos para a prática das atividades desportivas, a Alpargatas arca com o material necessário, "bolas, uniformes, tênis certo, todo o material esportivo né? Rede, essas coisas" (diretora). Isso poderia ajudar os alunos a se interessarem e se envolverem mais com a escola, e assim, de certa forma não serem tão influenciados pelas más companhias na rua. No entanto, não é bem o que acontece, há falta de manutenção do espaço e dedicação profissional.

A escola tem boa estrutura física, mas carece de cuidados. Na verdade, precisa é de uma reforma mesmo. São tomadas de energia expostas e ao alcance das crianças, quadra sem traves e postes, refeitório com bancos sem assento, paredes descascadas e furadas por balas de revólver, estes, dentre outros fatores preocupam a segurança dos alunos da escola.

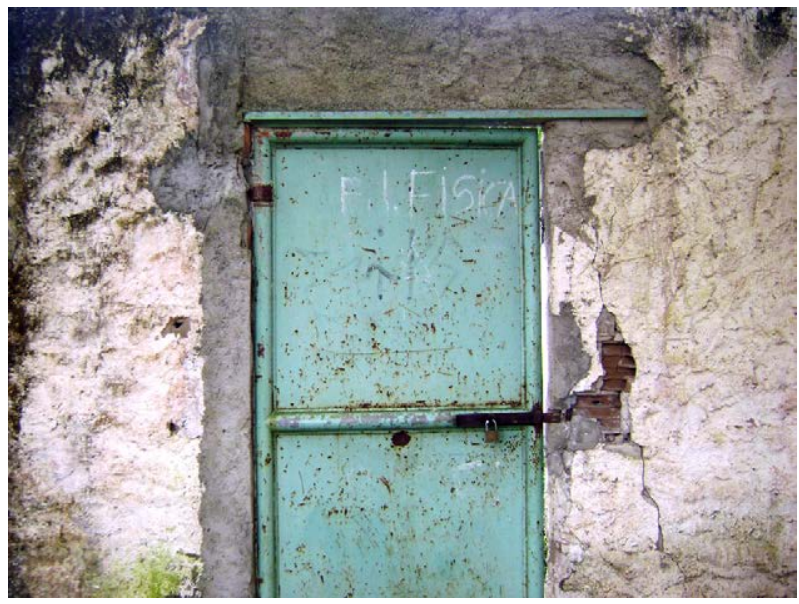

Imagem 02: Parede furada por projéteis com passagem para área de práticas físicas.

Fonte: Arquivo GCEM 


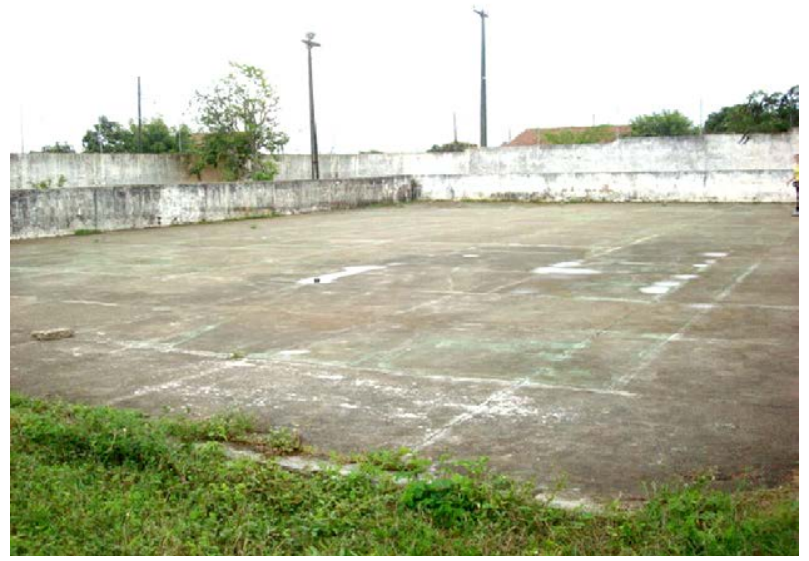

Imagem 03: Quadra poliesportiva

Fonte: Arquivo GCEM

Quanto às atividades realizadas, a entrevistada relata os seguintes fatos:

Esses meninos só conhecem bola, [...] esqueceram muito o lado lúdico né, a parte recreativa, alguns jogos como antigamente, na hora do recreio os meninos só brincam de correr, aí vem aquela coisa que poderia justamente, se tivesse uma outra parte recreativa, envolvê-los não é, como antigamente não é, que a gente trabalhava o quê né, a gente via amarelinha, a gente via o pula corda, a gente via o bambolê[...] 0 recreio aqui é absurdo, é tapa, é beliscão, é pancadaria, uma violência incrível, sabe. E eu acho que se fosse trabalhado bem essa parte recreativa, as crianças tinham mais afeto às regras, porque disciplina é regra, e eles não têm o hábito de obedecer, de ter limites, e é só saber lidar com essa falta de limites da família (Diretora).

No relato da diretora da escola, vemos que os investimentos feitos pelo Instituto Alpargatas ainda não surtiram efeito, e cita a falta de investimento nas atividades recreativas de cunho educativo, trabalhando essencialmente o esporte competitivo. 
Entendendo a recreação como parte prática, vivencial e que está presente na formação do indivíduo, vê-se a preocupação das instituições de ensino em proporcionar essa prática aos seus alunos já que, como considerada por Marcellino (2008), a recreação é veículo e objeto de educação, considerando além das possibilidades de descanso e divertimento a de desenvolvimento pessoal e social, ainda assim é fundamental que seja uma atividade de caráter desinteressado, não tendo os benefícios trazidos como foco e sim a vivência.

\section{Reconhecimento de espaços e interesses de lazer no bairro e ações de manifestação cultural}

O lar é o principal equipamento não-específico, este é "um dos poucos equipamentos, disponíveis para grandes parcelas da população "empurradas" para dentro de suas casas no tempo disponível para o lazer. Exatamente essas pessoas têm condições para o desenvolvimento do lazer nas suas habitações" (MARCELLINO, 2008, p.17).

Existem dois locais com equipamentos específicos de lazer no bairro: a Associação de Cabos e Soldados, que é restrito aos cabos e soldados associados; e o Clube dos taxistas é aberto à comunidade mediante pagamento. São lugares onde a população pode utilizar para o lazer explorando interesses como: social e físico não só durante os fins de semana, quando os clubes são abertos, mas também quando alugados, já que os mesmos oferecem essa possibilidade para comemorações de aniversários e casamentos, shows e confraternizações. Não sendo esta a principal finalidade destes, trata-se de instituições corporativas, que são orientadas para a defesa política de interesses setoriais ou grupais (sindicatos ou associações de classe ou de região) ou para o consumo coletivo (clubes) (PEREIRA; GRAU, 1999).

As práticas de lazer necessitam de espaços para fortalecer as relações com os sujeitos, causando satisfação pessoal, pois o fato de ocupar um espaço significa a necessidade de estar subordinado a alguns conteúdos culturais. Veremos a seguir algumas das atividades de lazer 
que acontecem, no bairro, ligadas aos seus interesses, seja ele social, físico, intelectual, manual e/ou artístico (DUMAZEDIER, 1980).

Numa visita ao bairro, foi possível encontrar crianças utilizando um terreno baldio para empinar pipa, jogar futebol, pedalar bicicletas, além de vizinhos, nas calçadas, conversando e observando o que acontece na rua. Mesmo violento, o bairro tem vizinhos amigáveis e oferece espaço para realização de tais atividades, seja na casa ou calçada do amigo, num bar ou em reuniões de SAB ou Igreja.

A igreja tem um papel muito importante na comunidade, pois como mencionamos anteriormente, realiza várias atividades que proporcionam o lazer. Há quatro anos que em abril é realizada a festa do padroeiro da comunidade, uma semana toda é dedicada a ele - dos sete dias, três são com festa oferecida à comunidade.

Em junho, na cidade do Maior São João do Mundo, não podia faltar nossa querida comida típica. São agendados dois dias para comemorar, a pamonha, a canjica, o milho assado e cozinhado, tudo feito pelos moradores para vender e arrecadar fundos para a igreja. De toda forma é um trabalho voluntário e gratificante para os que participam e está dentre outras vivências supracitadas inserido no interesse social. O presidente diz que "Todo ano eu tenho obrigação de trazer quadrilhas juninas pra se apresentar no nosso bairro no mês de junho".

Em setembro, é realizado o Festival do Sorvete, beneficiando principalmente as crianças, já foi fechada a rua para que fossem feitas brincadeiras na mesma. A SAB também sempre relembra datas comemorativas como Dia das Mães, o Dia dos Pais e Dia das Crianças.

O Jardim Borborema Fest é um Festival de bandas marciais que ocorre na própria rua, é o grande evento realizado pela $\mathrm{SAB}$, o mesmo conta com a participação da massa na comunidade "Nós já vamos para o terceiro ano, este ano, é do Jardim Borborema Fest. Cada ano vem crescendo o evento, graças a Deus é um sucesso, esse ano foi maior do que os outros anos. Todo mês de agosto a gente faz essa manifestação." (Presidente da SAB).

A criminalidade em parte do bairro já é conhecida, subtende-se que a decisão também tenha ocorrido "por conhecer o comportamento 
de certos moradores. A grande dificuldade apontada pelo gestor é na área de comunicação, que nem sempre a gente tem a comunicação ao nosso favor.(...) o pessoal adora a participação."

A escola relata um antigo Jornalzinho, no bairro, um ano atrás, hoje não encontramos nenhum veículo de comunicação sobre os informes internos do bairro. Este foi editado durante um ano por estudantes estagiários do curso de comunicação social da UEPB. Hoje a divulgação da maioria do que há na comunidade para a comunidade é feita através de carros de som ou panfletos.

O Bairro dispõe de uma extensa pista de caminhada (calçada da Av. Juscelino Kubitschek) que alcança também o bairro do Cruzeiro. Esta é a que deixa mais evidente a relação saúde e lazer. A caminhada além de promover a saúde, também, traz a sensação de bem-estar, muitos vão com amigos, se não vão, encontram a vizinhança. É um equipamento onde é possível ver pessoas de todas as idades e remete-se aos interesses físico e social.

São nas atividades de interesses físicos que encontramos pessoas interessadas na promoção de saúde, seja esse intuito para evitar doenças futuras, na recuperação de algo já detectado, ou no benefício desinteressado (BAGRICHEVSKY; ESTEVÃO E PALMA, 2003).

Em apoio às atividades realizadas, no local, a prefeitura Municipal da cidade realiza o projeto Campina Bem-estar ${ }^{2}$ que visa "promover a prática de atividades físicas de forma planejada e eficiente, como forma de melhorar as condições de saúde da população, através da realização de uma avaliação física das pessoas que costumam fazer caminhadas sem qualquer acompanhamento" (Prefeitura Municipal de Campina Grande, 2008).

2 Dentro das ações rotineiras de saúde são realizadas aferições de pressão arterial, avaliação física (com verificação de peso, altura, freqüência cardíaca, medição de percentual de gordura corporal e índice de massa corporal). 


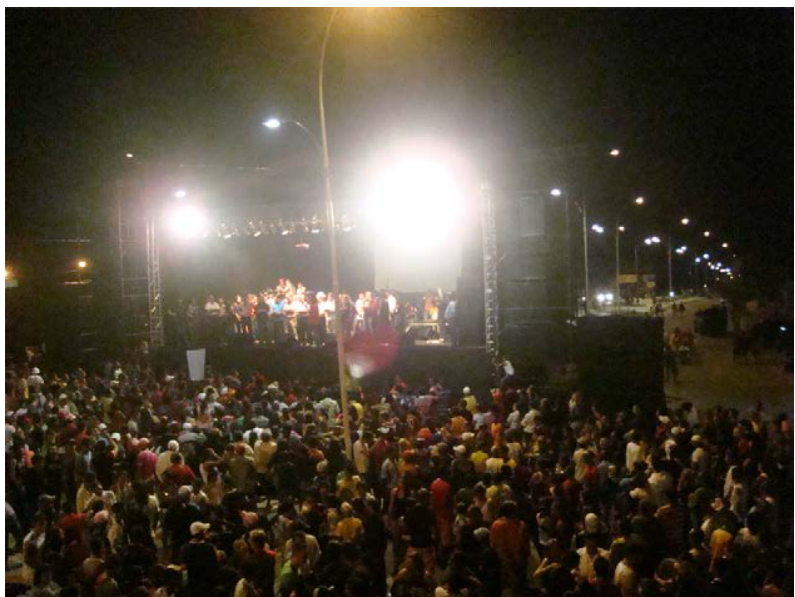

Imagem 04: Inauguração da pista de caminhada da Av. Juscelino Kubitschek em 08 de maio de 2009.

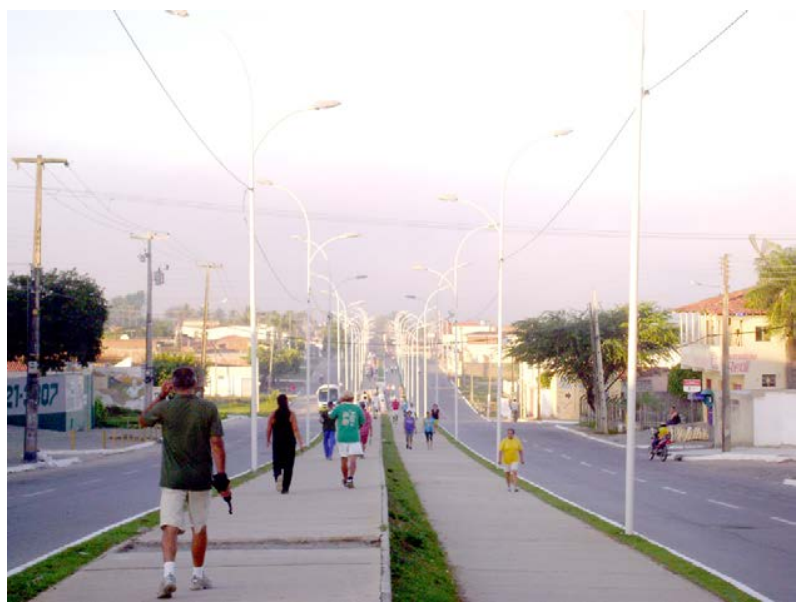

Imagem 05: Pista de caminhada - zona urbana Fonte: Arquivos GCEM 
A construção da pista também serve de incentivo e dá oportunidade à comunidade de estar realizando um novo evento, em 01 de maio de 2009, em comemoração ao Dia do Trabalho, a SAB do Jardim Borborema promoveu a $1^{a}$ c corrida e Passeio Ciclístico do Trabalhador.

A SAB em parceria com a UEPB já ofereceu as instalações para que fosse realizado um projeto de Extensão que proporcionasse atividades físicas orientadas à comunidade. 0 presidente diz que a maior clientela no projeto, que era realizado nas segundas, quartas e sextas, eram as idosas moradoras do bairro.

A rua e terrenos baldios encontrados, no bairro, são outro espaço de lazer, mais visto sendo utilizado pelas crianças, em um deles observaram-se crianças reunidas para o futebol, esporte recreativo mais encontrado, talvez por não precisar de muitos equipamentos, para eles com uma bola e quatro pedras "está tudo certo". Foram vistas, também, crianças pedalando bicicleta, empinando pipa.

A quadra da escola do bairro, apesar da falta de manutenção é um dos únicos equipamentos específicos do esporte recreativo. Quanto à utilização por parte da comunidade, a diretora respondeu que "Ela é aberta a comunidade nos finais de semana" com exceção dos horários em que ocorre "o projeto capoeira [...] que o município tem contrato com alguns professores de capoeira, que também é um esporte e no sábado acontecem essas aulas de esporte de capoeira para os alunos que não podem ir durante a semana".

O Jogos Internos fazem parte do lazer da maioria da população, pois os alunos se divertem, estejam jogando ou torcendo juntamente com os familiares e amigos. Um morador do bairro relata que, há cerca de cinco anos, existiam oito times de futebol, hoje tem conhecimento de apenas um, diz também que, quando a quadra era cedida à associação de moradores, promovia até campeonatos entre as equipes.

Tratando-se dos espaços de interesses intelectuais de lazer, podemos perceber a existência, tanto na escola quanto na $\mathrm{SAB}$, de bibliotecas, que são uma opção, mesmo que limitada, já que a escola é que determina o horário que irão até a mesma, e a SAB carece de recursos humanos para trabalhar com a sua. A SAB já contou com o apoio de 
uma voluntária, esta saiu por conseguir um trabalho. Desde então, não encontraram quem continuasse com os serviços.

A busca contínua por quem desenvolva atividades utilizando e assumindo a biblioteca mostra mais uma vez o interesse em facilitar o acesso da comunidade ao mundo das letras, ao conhecimento e leituras edificantes que sejam vistos não só como necessidade escolar, mas como o crescimento desobrigado.

'O Pró-Jovem, programa do Governo Federal em parceria com o município, usa sala da SAB para as atividades que envolvem jovens do Jardim Borborema e bairros vizinhos. 0 grupo também tem acesso à biblioteca, mas ainda sente necessidade de um espaço maior para realizar as atividades recreativas, que se realizam uma vez por semana.

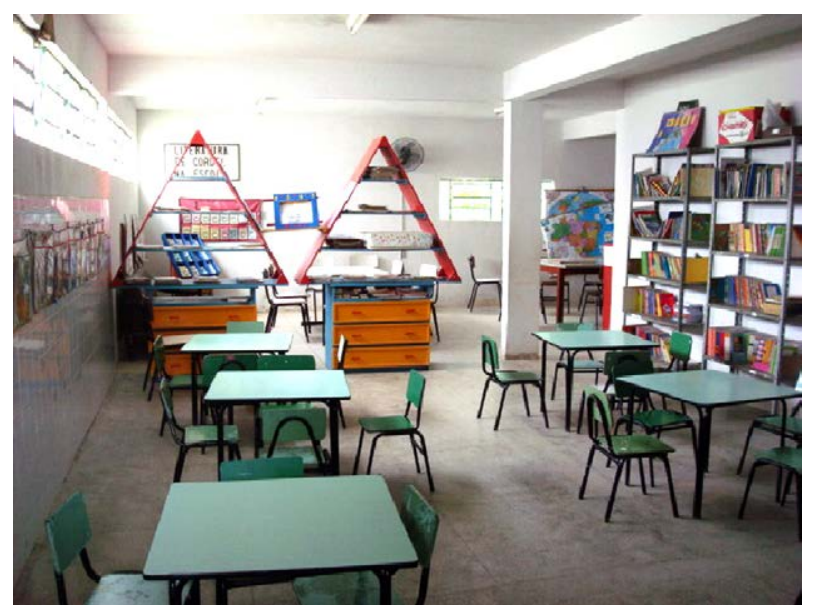

Imagem 06: Biblioteca da escola 


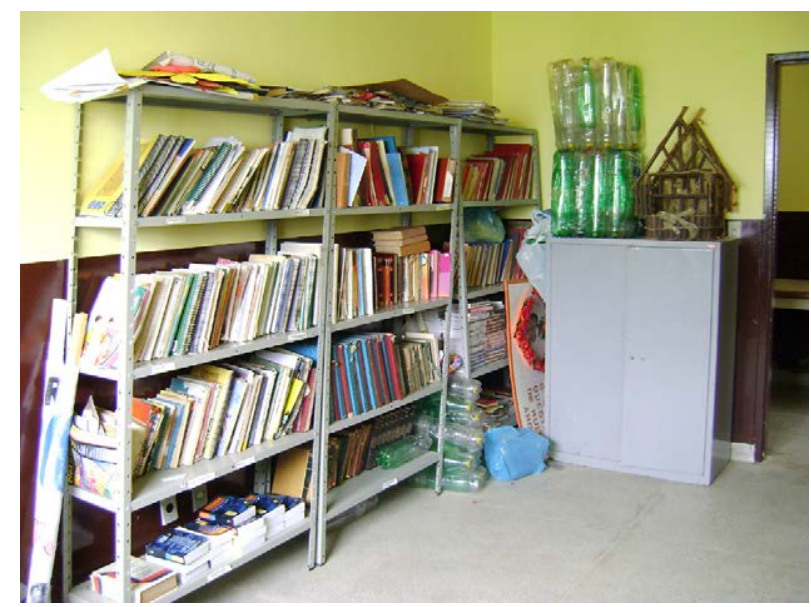

Imagem 07: Biblioteca da $\mathrm{SAB}$

Fonte: Arquivos GCEM

Existem lan houses, bem frequentadas, ou mesmo internet em casa. Como já mencionado, a SAB pensa em montar um laboratório de informática, a escola também tem sua sala de informática pronta, no entanto, faltam os computadores, para que assim a comunidade possa desfrutar do que a tecnologia oferece.

Por ser um bairro de limite com a zona rural, é possível observar muitas criações de animais em "quintais" de área verde e currais em meio às casas. Desta maneira formam-se ruas sem planejamento, infraestrutura e rede de esgoto. 0 que dificulta na implantação de políticas públicas de lazer e saúde. 


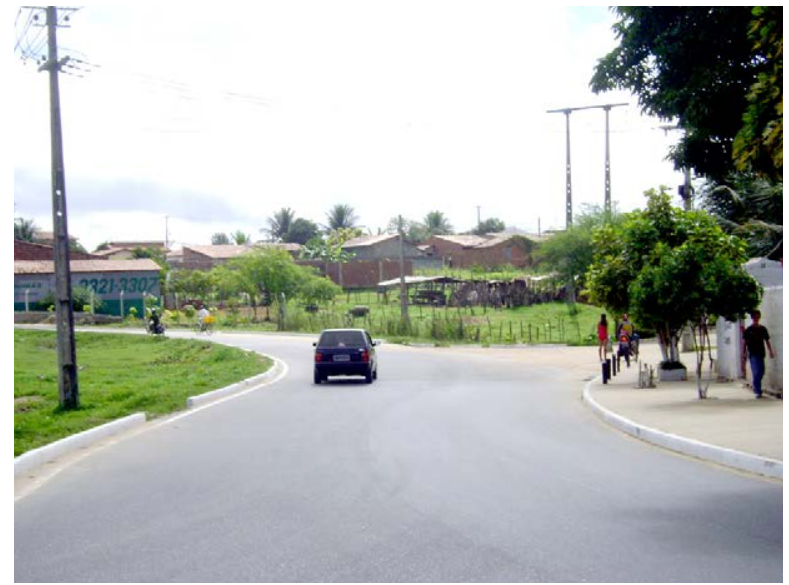

Imagem 08: Interface zona urbano/rural

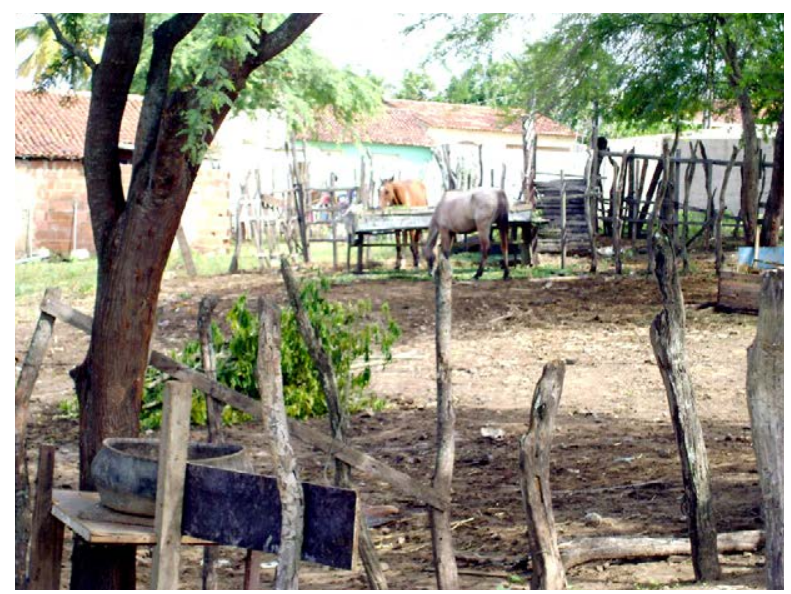

Imagem 09: Zona rural

Fonte: Arquivos GCEM 
Em meio à situação, a escola aproveita a oportunidade de lidar com a consciência ambiental. A unidade é bem arborizada e tem programas de ação ambiental realizados com profissional responsável por tudo da área. Junto aos alunos, ela cuida de uma horta onde cultivam o que pode ser utilizado na preparação da merenda. Também mudas de diversas árvores são cuidadas por eles.

No trabalho ecológico da escola, as crianças usam sua criatividade com sucata para embelezar o ambiente onde ficam as plantas. Este está inserido nos interesses manuais, por ser feito através da manipulação em sua forma plena (DUMAZEDIER, 1980). Como também é notável a falta de reforma ou manutenção na escola, como pintura, os alunos foram convidados a usar sua imaginação e expressar sua criatividade em paredes da escola na prática dos interesses artísticos, gerando encantamento, mostra uma sensação de quem o produz, universo estético feito de imagens e emoções, de sentimentos e imaginário (DUMAZEDIER, 1980).

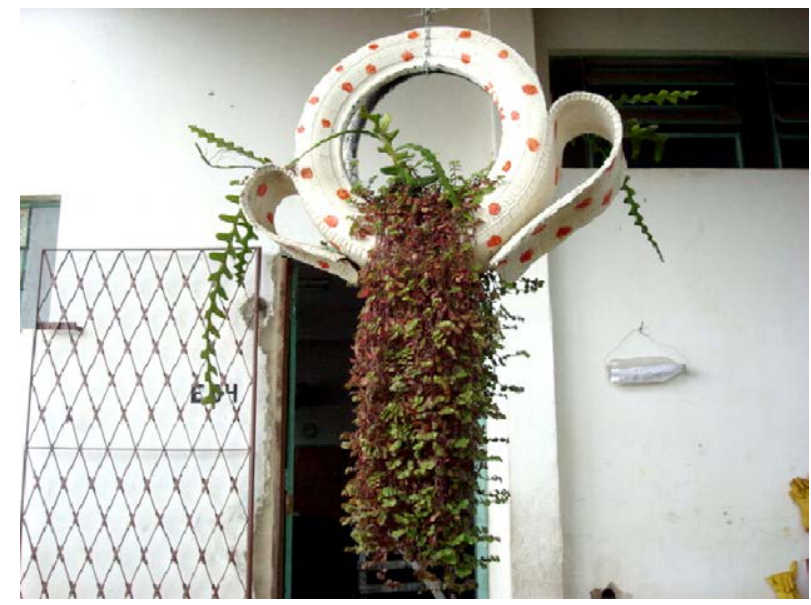

Imagem 10: Xaxim de material reciclado trabalhado artisticamente 


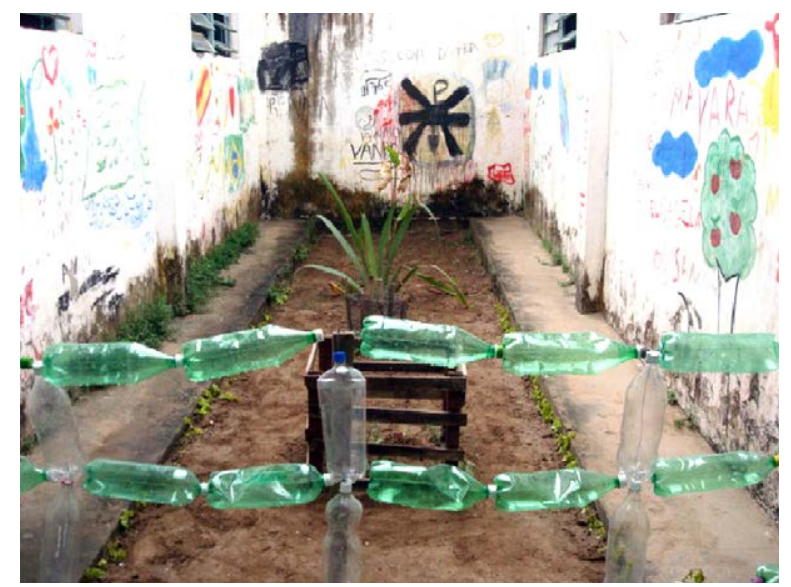

Imagem 11: Espaço revitalizado com arte em grafite e cerca de material reciclado

Fonte: Arquivos GCEM

A SAB oferece cursos que exigem criatividade e trabalho manual, como de pintura, corte e costura e no bordado. Também é desenvolvido um trabalho em parceria com a prefeitura para atender às pessoas especiais. 0 trabalho conta com assistente social, pedagogo e psicólogo. Os encontros realizados uma vez por semana oferecem assistência especializada para promover o bem-estar e crescimento pessoal destes.

Como observado no bairro, a rua é um importante espaço de lazer. Nela, as crianças brincam, são realizadas festas e festivais. Desta forma, o imaginário e a livre expressão ganham vida e enriquecem as experiências.

\section{Considerações finais}

O Bairro Jardim Borborema, apesar de pouco favorecido por investimentos e políticas públicas de lazer, consegue vivenciar a cultura lúdica nos limitados espaços que as escolas, a SAB, a Igreja, as ruas e quando pago, no Clube dos Taxistas e no Clube dos Sargentos e Cabos da Polícia oferecem. 
As condições de infraestrutura são precárias, havendo muitos terrenos baldios cortados pelo esgoto a céu aberto e muitos animais soltos no bairro, podendo provocar zoonoses e mesmo acidentes.

Não se pode calar diante das autoridades e é importante sim a reivindicação por melhorias relacionadas à área de lazer. Buscar o compromisso público através de possibilidades de construções e realizações que incentivem práticas saudáveis de lazer, capazes de contribuírem para o crescimento e desenvolvimento humano e social e, consequentemente, para a qualidade de vida (Chemin, 2007).

É necessário uma atenção maior por parte dos órgãos públicos, muitas promessas já foram feitas, segundo a atual presidente do Clube de Mães, mas passada a eleição, fica tudo do mesmo jeito. A única saída que encontram é fazer o requerimento de um ônibus ao CRAS (Centro de Referência de Assistência Social) e ir passear em clubes nas proximidades da cidade.

Através da SAB, da Associação de Moradores e do Clube de Mães, o bairro já conseguiu alguns espaços para os moradores, porém todos limitados por muros ou esgotos a céu aberto. Desta forma, percebese uma necessidade de um trabalho mais efetivo de conscientização dos direitos que a comunidade tem e uma articulação maior entre suas entidades representativas, já que atualmente as questões de política partidária estão separando os representantes e isso só tem trazido problemas à comunidade.

\section{Referências}

BAGRICHEVSKY, Marcos; PALMA; Alexandre; ESTEVÃO; Adriana. Análise sobre os limites da inferência causal no contexto investigativo "exercício físico e saúde". In: BAGRICHEVSKY, MARCOS; PALMA, ALEXANDRE e ESTEVÃO, ADRIANA. A Saúde em Debate na Educação Física. Blumenal:Edibes, 2003.

BRUHNS, Heloisa Turini. Introdução aos Estudos do Lazer. Campinas: UNICAMP, 1997 
CARVALHO, Yara M. Lazer e saúde: a sociedade e o social. In: MARCELLINO, Nelson Carvalho. Lazer e Sociedade - Múltiplas Relações. Campinas: Alínea, 2008.

CASTRO, Mônica da Silva. Modelo da Atividade Recreação: módulo programação. Rio de Janeiro: SESC, Departamento Nacional, 2007.

CECCIM, Ricardo Burg; BILIBIO Luiz Fernando. Singularidades da educação física na saúde. In: FRAGA, Alex Branco e WACHS, Felipe. Educação Física e Saúde Coletiva: políticas de formação e perspectivas de intervenção. Porto Alegre - RS: Editora UFRGS, 2007.

CHEMIN, Beatriz Francisca. Políticas Públicas de Lazer: o Papel dos Municípios na sua Implementação. Curitiba: Juruá, 2007.

FALCÃO, José Luiz Cirqueira; SARAIVA, Maria do Carmo (Org.). Esporte e Lazer na cidade: práticas corporais re-sigificadas. Florianópolis: Lagoa Editora, 2007.

GABRIEL, Oldrey Patrick Bittencourt. Lazer e Religião: algumas aproximações. In: MARCELLINO, Nelson Carvalho. Lazer e Sociedade - Múltiplas Relações. Campinas: Alínea, 2008.

MARCELLINO, Nelson Carvalho. Lazer e Esporte: políticas públicas. Autores Associados, 2001

Nelson Carvalho. Lazer e Educação. 12 ed. Campinas: Papirus, 2007.

Nelson Carvalho. Lazer e Sociedade - Múltiplas Relações. Campinas: Alínea, 2008.

MARIANO, Stéphanie Helena \& MARCELLINO, Nelson Carvalho. Equipamentos de lazer em cidades pequenas de região metropolitana. $R e$ vista Motriz - Equipamentos de Lazer. Rio Claro, v. 14, n. 2, p. 168-178, abr./jun. 2008 
MÜLLER, Kathia T. Organização de moradores numa perspectiva de necessidades radicais. 1992 Dissertação (Mestrado em Sociologia Política) - Universidade Federal de Santa Catarina, Florianópolis, 1992.

PINTO, Leila Mirtes Santos de Magalhães. Desafios para as Políticas Públicas de Lazer no Brasil. In: Encontro Nacional de Recreação e Lazer, 20, 2008, São Paulo. Anais... São Paulo, 1994. CD-ROM.

Leila Mirtes Santos de Magalhães. Lazer e Educação: desafios da atualidade. In MARCELLINO, Nelson Carvalho. Lazer e Sociedade - Múltiplas Relações. Campinas, SP: Editora Alínea, 2008.

PEREIRA, Luiz Carlos Bresser; GRAU, Núria Cunill (org). O público não estatal na reforma do Estado. Rio de Janeiro: Fundação Getúlio Vargas, 1999.

PREFEITURA MUNICIPAL DE CAMPINA GRANDE - Portal da Transparência. Cerca de 40 mil atendimentos pela campina bem-estar. Disponível em: <http://www.pmcg.pb.gov.br/transparencia/eixos/cidadania/14.php>. Acesso em: 15 jan 2009.

RECHIA. Simone. A Política de Lazer na Cidade: Em Pauta: "A Análise da Gestão dos Espaços em Distintas Realidades e Segmentos Populacionais. In: Encontro Nacional de Recreação e Lazer, 20.,2008. São Paulo. Anais... São Paulo, 1994. CD-ROM.

RESENDE, Lenise. "Festas Religiosas Populares". Almanaque Abril 1995 / 2001; Globinho Pesquisa. Disponível em: <http://www.lendorelendogabi.com/folclore/festas_religiosas_populares_pag4.htm>. Acesso em: 09 mai 2009.

SAMPAIO, Tânia Mara Vieira. Gênero e Lazer. In MARCELLINO, Nelson Carvalho. Lazer e Sociedade - Múltiplas Relações. Campinas, SP: Editora Alínea, 2008. 
ZINGONI, Patrícia. O lugar das famílias nas Políticas de Lazer in MARCELLINO, Nelson Carvalho. Lazer e Sociedade - Múltiplas Relações. Campinas, SP: Editora Alínea, 2008.

"Ação Escola". Disponível em: <http://www.institutoalpargatas.com. br/index.php?Projeto-Acao-Escola>. Acesso em: 17 jan 2009. 


\title{
Tensões e contradições no cotidiano lúdico do catolé
}

\author{
Emília Amélia Pinto Costa da Silva \\ Eduardo Ribeiro Dantas
}

Este artigo tem como proposta discutir o cotidiano lúdico do bairro do Catolé, localizado na cidade de Campina Grande - PB. Para tanto, partiremos do surgimento do bairro, contextualizando sua formação. Em seguida, iremo-nos concentrar na sua situação atual, em se tratando das experiências de lazer de seus moradores.

O bairro do Catolé está localizado na Zona Sul da cidade, possuindo segundo o Instituto Brasileiro de Geografia e Estatística - IBGE (2002), 17.034 habitantes, sendo um dos três bairros mais populosos de Campina Grande.

O primeiro nome dado ao bairro foi "Sítio Baixa de Pau", pois encontrava-se em uma área mais isolada da cidade, sem muito desenvolvimento. Possuía algumas casas de farinha e o resto era um grande roçado. Posteriormente, na medida em que foi crescendo, passou a ser chamado Catolé. Após a construção do maior estádio de futebol da cidade, o "Amigão", no início da década de 70, o processo de pavimentação das ruas do bairro contribuiu muito para sua ampliação (JORNAL DA PARAÍBA, 2006).

Situa-se em uma área que vem se valorizando muito do ponto de vista imobiliário, chegando a possuir, hoje em dia, um dos metros-quadrados mais caros da cidade (JORNAL DA PARAÍBA, 2006). 
Em um contexto geral, as condições socioeconômicas do bairro atualmente são bastante heterogêneas, mesmo que a renda média mensal dos seus moradores, calculada em R $\$ 970,34$ pelo IBGE (2002), seja mais alta do que a encontrada em muitos outros bairros da cidade.

0 crescimento desordenado do bairro revela, em cada rua e esquina não saneadas das espécies de guetos que ali proliferaram, as tensões e contradições sociais próprias aos grandes centros urbanos das sociedades contemporâneas.

Para pensarmos a gestão do esporte recreativo e do lazer em um contexto tão contraditório, levando em conta a necessidade de políticas públicas, sejam elas intersetoriais ou não, optamos por uma compreensão mais horizontal da relação entre o poder público e os mais diversos grupos da sociedade civil organizada, na qual os interesses coletivos se sobrepõem aos individuais e as diferenças sociais são minimizadas em favor da vida em comum.

Compreensão esta, em que a mobilização social surge como um conceito chave para a superação do paternalismo político que ainda insiste em se perpetuar enquanto lógica de administração da vida pública, comprometendo o exercício da cidadania e o estabelecimento de uma ordem democrática legítima (TORO; WERNECK, 2007).

Seguindo o pensamento de pesquisadores que entendem a participação popular como um elemento de inovação em gestão pública nas mais diversas áreas, passamos a descrever agora a situação do esporte recreativo e do lazer no bairro do Catolé, tendo como ponto de partida as políticas públicas que atingem os moradores do bairro e algumas de suas comunidades organizadas.

\section{Discutindo as políticas públicas de lazer no Catolé}

De acordo com Chemin (2007), as políticas públicas são os meios pelos quais a Administração do Estado efetiva as disposições constitucionais. Desse modo, compreendemos que as políticas públicas de lazer, têm como função, promover ações que visem garantir o direito ao lazer, através do exercício da cidadania. 
Consideramos, ainda, que as políticas públicas de lazer devem ser constituídas por projetos, programas, leis e outras estratégias, que tenham uma atenção especial com o desenvolvimento das cidades brasileiras, onde no cotidiano da população, o lazer é vivenciado efetivamente.

Até mesmo porque, os espaços e equipamentos públicos de lazer existentes, nos centros urbanos, são adequados à vivência de diversos interesses culturais, podendo ser utilizados pela população em diferentes aspectos. Deste modo, estes ambientes são atraentes por motivo da inexistência de uma determinação da forma de uso, permitindo aos frequentadores utilizá-los da melhor maneira possível (RECHIA, 2008).

Dialogando com o pensamento de Bauman (2009) sobre o espaço público, destacamos ainda que são, nesses locais, que as diversas formas de convivência social emergem, expressas nas dores, alegrias e esperanças da população. De acordo com o autor, no espaço público, a atração e a rejeição da convivência social se entrelaçam, de forma a nos darem a chance de superar ou reforçar as diferenças que nos separam, o que mostra a importância do espaço público para a vida coletiva.

No bairro do Catolé, um dos espaços públicos onde podemos perceber a convivência não só de moradores de diferentes classes sociais, mas também de outras localidades da cidade, é o "Parque da Criança", onde funciona um projeto da Prefeitura Municipal de Campina Grande, chamado "Campina Bem-Estar". Projeto este, que disponibiliza, para os frequentadores do parque, aulas de ginástica, verificação da pressão arterial, verificação de peso e altura, entre outros serviços.

Dentro do parque, localiza-se também uma biblioteca, que é resultado de um projeto do Serviço Social da Indústria - SESI, chamado "A Indústria do Conhecimento", onde a comunidade tem acesso a livros e revistas, além de computadores.

Outras ações de lazer encontradas, no parque, são as aulas de Tai Chi Chuan e Capoeira, que abrindo espaço para qualquer usuário, não estão vinculadas a qualquer projeto ou programa do poder público. 
O espaço do "Parque da Criança" é bastante utilizado para os eventos da cidade, tais como o "Dia da Criança" e o "Domingo no Parque", além de competições e outras ações promovidas pelos órgãos públicos.

Dessa forma, percebemos que o bairro do Catolé recebe um dos espaços de lazer mais movimentados da cidade, que através de seus equipamentos e projetos específicos de lazer, possibilita a vivência lúdica da população de Campina Grande.

Mesmo assim, acreditamos que o "Parque da Criança", por si só, não atende todas as demandas lúdicas da cidade, necessitando de maiores investimentos tanto do ponto de vista estrutural, quanto humano. Como se trata de um local distante até mesmo de certas áreas do bairro, questionamos se ele está sendo apropriado aos moradores mais carentes do Catolé, que social e geograficamente longe do parque, podem estar tendo o seu direito ao lazer comprometido pela falta de um espaço público mais próximo de suas vidas.

Neste sentido, precisamos de maiores reivindicações para a conquista desses espaços, já que as possibilidades de transformação social dependem também da democratização do lazer, que em última análise, está relacionada à democratização do espaço.

\begin{abstract}
Muito embora as pesquisas realizadas na área das atividades desenvolvidas no tempo livre enfatizam a atração exercida pelo tipo de equipamento construído, deve-se considerar que, para a efetivação das características do lazer é necessário antes de tudo, que ao tempo disponível corresponda um espaço disponível (MARCELLINO, 1995, p. 57).
\end{abstract}

Assim sendo, é necessário que a população se envolva na elaboração das políticas públicas de lazer, reivindicando ações que beneficiem a comunidade, em geral, e não apenas segmentos dela. A seguir, iremos discutir as possibilidades de participação popular no Catolé, a partir de elementos identificados em nossa pesquisa de campo. 


\section{Interfaces entre lazer e educação}

Para uma melhor aproximação do bairro, realizamos uma entrevista em uma de suas escolas municipais. A atual gestora está nesta função há quatro anos. Esse cargo foi escolhido através de uma votação entre funcionários em geral, pais e alunos da respectiva escola.

A escola funciona nos três turnos, sendo o turno da noite para educação de jovens e adultos. Apenas um turno é contemplado com aulas de Educação Física, que são alunos da tarde. A diretora expõe que a Secretaria de Educação escolheu o turno da tarde, pois é o horário que tem mais alunos matriculados.

O turno da manhã tá sem professor de Educação Física. Aí a gente fica numa situação, os bichinhos da manhã, os meninos da manhã não tem... é... é... as professoras é que brincam com eles no momento de recreação, na verdade é uma recreação, mas... é... pra Educação Física não tem não para manhã (Presidente da SAB Catolé).

Neste caso, percebemos que a Educação Física, enquanto componente curricular, não está sendo tratada como um dos caminhos que proporcionam uma educação para o lazer, já que para a maioria dos alunos da escola, ela é vivenciada apenas como uma atividade física.

Precisamos que a Educação Física e seus objetivos na escola sejam repensados, para que possam estar colaborando com a reflexividade de seus alunos, no sentido de reforçar o entendimento do lazer como uma dimensão da vida humana. A Educação Física, em apenas um dos turnos, afasta a maioria dos alunos dessa perspectiva, uma vez que, enquanto componente curricular obrigatório da educação básica, ela tem a função de inserir e integrar todos os alunos na cultura corporal do movimento (BETTI; ZULIANI, 2002).

Para suprir as necessidades da escola na área da Educação Física, ela tem uma parceria com o Instituto Alpargatas e o Instituto Camargo Corrêa, através do projeto "Escola Ideal", que tem o objetivo de beneficiar as escolas públicas, fortalecendo o elo da criança com a escola através da Educação Física (INSTITUTO ALPARGATAS, 2008). 
Com a implantação desse projeto, a escola municipal investigada foi contemplada, no ano de 2008, com equipamentos de esporte e lazer até então inexistentes na instituição. Foram doadas, por exemplo, bolas, jogos de xadrez, dominós, damas, bolas de gude e rede de voleibol. Entendemos que as parcerias são importantes para a efetivação do direito ao lazer da população, mas não podemos deixar de lembrar da responsabilidade social do poder público, em ofertar Educação Física de qualidade para a população.

São muitas as dificuldades existentes na escola. No ano de 2009, ela recebeu $\mathrm{R} \$ 4.285,00$, para despesas gerais, tais como, papel, material de limpeza e material escolar. A diretora relata que as crianças da escola são carentes, e algumas delas não têm condições sequer de comprar um caderno.

Outra alternativa para a arrecadação de fundos para a escola, é a organização de bingos. Com o dinheiro arrecadado em um deles foi construído o playground, que trouxe novas possibilidades lúdicas para as crianças, como podemos observar na foto a seguir.

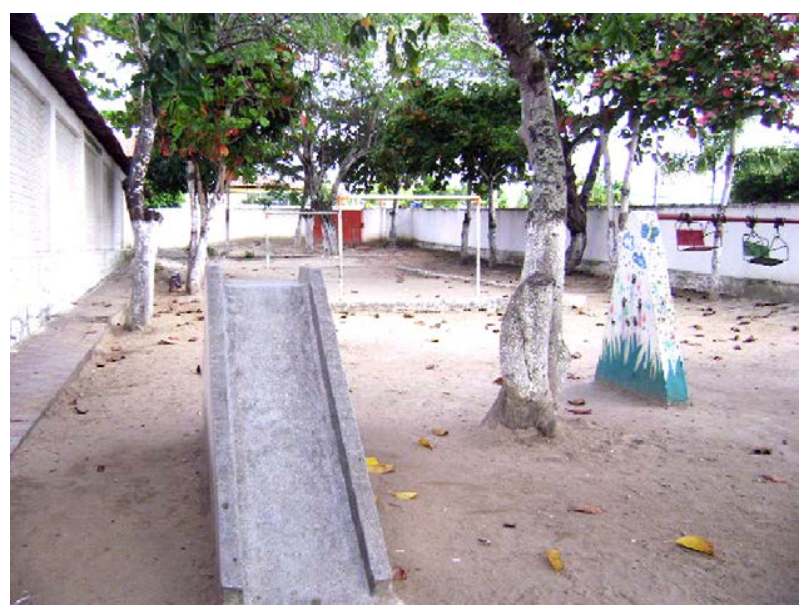

Imagem 01: Playground: novas possibilidades lúdicas

Fonte: Arquivos do GCEM 
Em relação à participação da comunidade na escola, existe o Conselho Escolar, composto por representantes dos alunos, dos pais, dos funcionários e dos professores. Mesmo com muitos pais ausentes, a escola se preocupa com a articulação junto às famílias. Todos os dias, no horário de chegada dos alunos, há uma acolhida, preparada por pais, alunos e professores. Cada dia da semana, há um encarregado na elaboração desse momento, o que torna interessante a participação dos pais, embora todos não estejam presentes.

Percebemos que a participação da população, nas questões escolares, remete mais à qualidade da aprendizagem que os alunos estão tendo, diferentemente da participação popular na Sociedade Amigos do Bairro - SAB Catolé, onde questões, de ordem mais geral do bairro, são colocadas, em pauta, para decisão conjunta dos moradores do bairro. Entendemos, porém, que a escola podia ser utilizada como um canal institucional mais atuante, na reivindicação de políticas públicas de esporte e lazer e não se limitar aos assuntos que envolvem a comunidade escolar.

\section{O lazer para os "Amigos do Bairro Catolé"}

A função social das SABs de Campina Grande é defender os interesses da população do bairro, servindo como mediadora entre os moradores e os governantes. Atualmente, elas são coordenadas pela União Campinense das Equipes Sociais - UCES, que tem o objetivo de orientar e fiscalizar as atividades promovidas pelas entidades associadas, bem como, incentivar seus representantes a construírem políticas públicas que contribuam com o desenvolvimento socioeconômico e o combate a pobreza (UCES, 2009).

A SAB do Catolé teve sua fundação em 1968, possuindo atualmente 609 sócios. Para se associar à SAB, as pessoas devem provar através do comprovante de residência, que são moradoras do bairro, podendo após isso, participar de todas as atividades dos associados, tais como as eleições da sua diretoria. 
A atual gestora comenta que nas eleições passadas, por falta de esclarecimento das delimitações do bairro, um dos moradores foi impedido de votar, por ter um comprovante de residência do bairro Itararé, situado ao lado do Catolé. Este morador precisou entrar na justiça para recuperar seu direito a voto, já que realmente fazia parte do Catolé. Neste caso, observamos que apesar de morar distante da SAB, o morador reconheceu seu direito de reivindicação através deste canal institucional, o que revela que mesmo sem uma participação maciça da população dos bairros, as SABs continuam sendo estruturas significativas para as reivindicações dos moradores de Campina Grande.

A SAB do Catolé possui prédio próprio e no mesmo local funciona o Clube de Mães. São realizadas reuniões frequentes, sendo que para anunciá-las, são expostos, na frente da $\mathrm{SAB}$, cartazes com o horário e a data das mesmas. Também é feita uma divulgação por meio de carro de som nas ruas do bairro.

A pauta da reunião é formulada através do contato que a presidente tem com a população, a partir das sugestões e reclamações que alguns moradores passam para a gestora. Para maior incentivo da participação da população nas assembleias, sempre é convidado algum secretário, vereador ou conselheiro, para chamar a atenção dos sócios, mas mesmo assim, não são todos os associados que comparecem às reuniões.

Segundo a presidente da SAB, os moradores reclamam em relação ao lixo colocado na frente da quadra. "A pauta da reunião é muita queixa do lixo que é colocado, exposto aqui na frente da SAB. Lixo mesmo que é os próprios moradores que coloca. E... a queixa é da segurança, saúde".

Reivindicações que, como pudemos presenciar, são de certa forma atendidas pelo poder público. Durante a nossa pesquisa de campo, a prefeitura da cidade limpou a área solicitada. Dois dias depois, porém, percebemos já uma pequena acumulação de lixo no local, depositado pelos próprios moradores do bairro, o que nos leva a alertar para a necessidade de uma maior educação ambiental da população.

Na primeira visita que fizemos à $\mathrm{SAB}$, a gestora mencionou que seria estipulada uma pequena taxa mensal aos sócios, para um melhor desenvolvimento da instituição. Em uma segunda visita, a gestora in- 
formou que essa taxa até o momento não está sendo cobrada, pela falta de atividades oferecidas pela $\mathrm{SAB}$, o que por si só gera um problema, já que um meio de manter o prédio é cobrar taxas de inscrições quando são oferecidos cursos.

Uma dificuldade citada pela atual gestora é o fato da SAB não possuir nenhum fundo financeiro, além de possuir algumas dívidas que foram deixadas pela gestão passada, que segundo a presidente, passou dezessete anos no poder. A atual gestora está lutando contra um processo, na justiça, para regularizar sua situação e conseguir novas parcerias.

Mas a gente quer limpar esse processo para que a gente possa trabalhar junto com o governo federal, estadual e municipal para desenvolver atividades de lazer, de esporte, na área de educação (Presidente da $S A B$ Catolé).

0 maior problema relatado foi à má condição que o prédio se localiza, necessitando de reformas. Mas, segundo notícia veiculada no site da UCES (2009), a Prefeitura Municipal de Campina Grande comprometeu-se com a construção, ampliação e reforma das sedes das SABs.

Na primeira ida a campo, em uma entrevista com a presidente da SAB Catolé, a presidente relatou um assalto, na $\mathrm{SAB}$, o que ocasionou a suspensão de alguns cursos que eram realizados, como curso de reciclagem e de secretariado. A única atividade desenvolvida era a atuação em parceria com o Programa Saúde da Família - PSF, que desenvolvia seu trabalho, distribuindo medicamentos, verificando a pressão e fazendo o controle do diabetes da população. Mesmo com essa atuação, observavam-se ainda algumas carências na promoção da saúde fornecida pelo PSF, como por exemplo, a falta de medicamentos.

Em outra ida a campo, percebemos novas iniciativas de atividades que são oferecidas para a população. Foi implantado, na SAB, o PróJovem $^{1}$, que é um curso oferecido para os jovens com objetivo de tirálos das ruas. Outra atividade implantada, na SAB, é um curso de evangelização para as crianças, que é realizado em parceria com a igreja Batista. Outro projeto que está para ser implantado na SAB, é o "Perfil"

1 A sede geral do Pró-Jovem em Campina Grande é localizada, no Complexo Desportivo Plínio Lemos, localizado no bairro do José Pinheiro. 
este, tendo a finalidade de oferecer cursos profissionalizantes para os jovens. Nesta perspectiva, compreende-se um avanço nas atividades oferecidas pela $\mathrm{SAB}$, em comparação ao primeiro contato que tivemos com ela.

A atual presidente está desenvolvendo uma pesquisa de opinião junto à população. Desee modo, está tendo contato com os moradores, com o objetivo de conhecer os problemas referentes à saúde, à educação e à infraestrutura, que o bairro enfrenta, para assim, convocar uma sessão com a população, convidando prefeito, vereadores e secretários, na tentativa de solucionar as dificuldades cotidianas.

Em relação às reivindicações populares relacionadas ao esporte recreativo e ao lazer, os moradores que frequentam as reuniões da SAB Catolé, reivindicam mais e melhores espaços de lazer.

Assim, a reivindicação é muita, né? Porque é preciso, é muita criança aqui, e a gente não tem nenhuma, assim, principalmente os pais, muitos trabalha e as crianças ficam em casa, no meio das ruas sem ter o que fazer, então, brincando com o lixo, não tem um espaço adequado para se divertir (Presidente da $S A B$ Catolé).

Mesmo que o lazer, muitas vezes, não seja mencionado como prioridade, quando tocamos no assunto das políticas públicas, podemos perceber que os moradores do Catolé sentem a necessidade de que o seu cotidiano lúdico seja reorganizado, a partir da intervenção do Estado. Isso é importante, já que estamos tratando de um bairro em que as opção para o lazer são muitas, mas em sua maioria, relacionadas ao consumo de bens e serviços, como iremos discutir a seguir.

\section{Espaços e equipamentos públicos de lazer no Catolé}

Ao andarmos pelas ruas do Catolé, observamos um grande número de condomínios fechados, contrastando com áreas invadidas pela população, que em condições precárias de moradia, submete-se à falta de uma infraestrutura adequada de habitação. Paradoxalmente, o bairro é 
privilegiado pela sua diversidade de opções de lazer, que, em sua maioria, estão ligadas ao consumo dos mais diversos bens e serviços.

No Catolé, localizam-se inúmeras opções privadas de lazer, tais como: os dois principais shopping-centers da cidade. Além disso, encontramos várias casas de shows e muitas escolhas de gastronomia, $\mathrm{o}$ que chama atenção de diversos jovens para se reunirem nas panquecarias, pizzarias, bares e outros estabelecimentos do local.

As contradições existentes, no bairro do Catolé, refletem-se, então, nas experiências de lazer da população, já que as muitas opções de lazer ligadas ao consumo atraem não só pessoas das mais altas classes sociais da cidade ao bairro, mas também de camadas mais humildes.

Além de espaços e equipamentos públicos e privados, encontramos, no bairro, aqueles locais que não se situam em nenhuma dessas categorias, como as associações profissionais, que têm regras específicas para a utilização de suas dependências. O Serviço Social do Comércio - SESC, por exemplo, oferece atividades físicas durante a semana e nos finais de semana, se transformando-se em opção de lazer para seus associados.

É preciso, porém, o investimento em espaços e equipamentos públicos de lazer, gratuitos e de qualidade, para que a parcela de moradores do Catolé, que não mora nos condomínios de luxo do bairro, possa ter efetivado seu direito ao lazer.

Esses espaços devem ter aparência agradável, para despertar o desejo da população em frequentá-los nos seus momentos de lazer. Muitas vezes, porém, apenas o embelezamento do local, faz com que ele seja transformado meramente em um cenário para os pedestres, ao invés de um espaço de descanso, contemplação e entretenimento.

Um dos espaços de lazer encontrados, no Catolé, é a quadra localizada às margens da $\mathrm{SAB}$ do bairro. Nesta área, existiam duas quadras que pertenciam à $\mathrm{SAB}$, sendo que uma delas foi vendida para a construção do estacionamento de um shopping-center da cidade e não se sabe no que o valor adquirido foi revertido. Neste aspecto, observamos a perda de mais um local para a iniciativa privada, reduzindo cada vez mais as oportunidades e as ofertas de opções de lazer para as populações mais humildes. 
Percebemos que, no bairro do Catolé, há um grande investimento nos espaços privados de lazer, o que desperta a atenção de muitos moradores da cidade. Por outro lado, as políticas públicas de lazer precisam de uma melhor atenção para promover a inclusão e a participação popular nas experiências de lazer.

A outra quadra da SAB ficou como um espaço livre para a população, no entanto, nessa quadra, nunca foi realizada nenhuma reforma para melhorar o piso, as traves e a área que cerca a quadra, como apontam alguns moradores e a gestora da instituição. Consequentemente, este espaço serve de depósito de lixo e restos de materiais de construção, o que ocasiona muitas queixas dos moradores circunvizinhos. Além do perigo que proporciona à saúde das crianças que brincam próximo ao lixo.

Segundo relato de um morador, ao lado da quadra, em uma grande área livre, também, era depositado lixo. Por iniciativa de outros moradores, foram plantadas árvores e colocados bancos para evitar uma maior poluição ambiental, que se reverte em danos de saúde para os próprios moradores. Essa iniciativa da população local foi de suma importância, pois os moradores do bairro também são responsáveis por um ambiente harmônico, juntamente com o poder público.

A prefeitura... vem. Fazem a limpeza do lixo. No dia seguinte já tem lixo. Então é preciso ter a reeducação da própria população para que elas se conscientizem de que eles e também a gente tem um pouco de atenção maior por causa dos governos... se a gente tira o lixo, e a própria população volta a colocar o lixo, por que não fazer outras medidas? Calça o pedaço de rua que tá ai, pra calçar, faz a revitalização do piso dessa quadra, eu acho que não tem muito custo quanto a limpeza frequente do lixão, e isso a gente pede, a gente reivindica, grita... (Presidente da SAB Catolé).

Alertando o poder público a tomar medidas que reduzam custos frequentes com a limpeza, de forma a beneficiar a população e ter uma estratégia da mesma não retornar a colocar lixo nesses locais, a SAB local consegue cumprir o seu objetivo de ser mediadora entre o Estado 
e a população, sem onerar os cofres públicos ou culpabilizar os moradores locais.

Outros espaços utilizados pelas crianças para suas brincadeiras são as ruas e os terrenos baldios do bairro. Assim, observamos principalmente, no final da tarde, a concentração delas em torno do futebol, da amarelinha ou das pipas, divertindo-se e se relacionando com as outras crianças. Como menciona a presidente da $\mathrm{SAB}$, quando questionamos os locais que as crianças brincam no bairro "nesse espaço aqui em frente e aqui ao lado da lavanderia tem um jogo de futebol toda tarde pelas crianças". Enquanto isso, alguns adultos ficam conversando nos bancos da praça, localizados ao lado da SAB.

Em relação aos espaços e equipamentos da escola investigada, encontramos uma quadra que, no momento, está sem areia. A outra quadra está com o piso em má conservação. Na escola também tem um playground de alvenaria, construído recentemente. De acordo com a diretora da escola, o Instituto Alpargatas está analisando a possibilidade de reforma da quadra, que terá traves, será pintada e também terá arquibancadas.

Ainda conforme a diretora, mesmo com carência de manutenção dos espaços e equipamentos existentes na escola, muitas crianças chegam cedo e saem mais tarde, para aproveitarem estes espaços. Notamos, então, a necessidade das crianças em vivenciarem o lúdico e a atração que os espaços fornecidos pela escola proporcionam a elas, fazendo com que sintam a vontade de permanecer dentro do ambiente escolar.

A seguir, apresentamos mais alguns dos espaços e equipamentos para o esporte recreativo e o lazer, existentes no bairro do Catolé. 
Tensões e contradições no cotidiano lúdico do Catolé

\begin{tabular}{|c|c|c|}
\hline Tipo & Quantidade & Condições de uso \\
\hline $\begin{array}{c}\text { Quadra em frente a SAB } \\
\text { Catolé }\end{array}$ & 1 & $\begin{array}{c}\text { Piso com buracos. Lixo } \\
\text { depositado ao lado. }\end{array}$ \\
\hline $\begin{array}{c}\text { Quadras do Parque da } \\
\text { Criança }\end{array}$ & 3 & $\begin{array}{c}\text { Piso desnivelado e redes } \\
\text { de proteção danificadas. }\end{array}$ \\
\hline $\begin{array}{c}\text { Playgrounds do Parque } \\
\text { da Criança }\end{array}$ & 2 & Faltam alguns balanços no playground \\
de madeira.
\end{tabular}

Quadro 1 - Espaços e equipamentos para o esporte recreativo e o lazer, existentes no Catolé

Alguns espaços e equipamentos não foram citados pelos gestores entrevistados. Consideramos necessário que os gestores das SABs e das escolas do bairro, reconheçam o cotidiano lúdico do Catolé, para que desse modo possam motivar e informar a população sobre as diversas manifestações culturais que são vivenciadas no local.

\section{Manifestações culturais presentes no bairro do Catolé}

Compreendemos o lazer como uma dimensão da cultura, sendo esta um conjunto de hábitos que conduz a vida da sociedade, variando de lugar para lugar (MELO; ALVES JÚNIOR, 2003). Sendo assim, é caracterizada pelas tradições e experiências vivenciadas pela população, que se expressa através dos movimentos corporais, vestimentas e músicas, entre outros aspectos. 
Segundo relato da presidente da SAB Catolé e da escola municipal visitada, no bairro, são comemoradas as festividades do Dia das Mães, dos Pais, São João e dia das Crianças, entre outras, que são organizadas pela escola e pela SAB. No dia das Mães e dos Pais, são realizadas homenagens. No São João, há quadrilhas para as crianças. A SAB recebe apoio de alguns comerciantes, empresários da cidade, prefeitura e governo do estado. No quadro a seguir, destacamos mais algumas das manifestações culturais e dos eventos existentes no bairro do Catolé.

\begin{tabular}{|c|c|c|}
\hline $\begin{array}{c}\text { Manifestações culturais } \\
\text { e eventos }\end{array}$ & Formas de vivência & Temporalidade \\
\hline Capoeira & $\begin{array}{c}\text { Aulas de Capoeira para } \\
\text { as crianças dos turnos } \\
\text { da manhã e da tarde }\end{array}$ & Semanal \\
\hline Dança & $\begin{array}{c}\text { Apresentação das qua- } \\
\text { drilhas da escola }\end{array}$ & $\begin{array}{c}\text { Mês de junho no São } \\
\text { João }\end{array}$ \\
\hline Boi de Carnaval & $\begin{array}{c}\text { Ensaio nas ruas e } \\
\text { na SAB }\end{array}$ & $\begin{array}{c}\text { Mês de Fevereiro e } \\
\text { no Carnaval }\end{array}$ \\
\hline Futebol & Partidas realizadas pelas \\
crianças & $\begin{array}{c}\text { Todos os finais da } \\
\text { tarde }\end{array}$ \\
\hline $\begin{array}{c}\text { Dia das mães, dos pais, das crian- } \\
\text { ças e São João }\end{array}$ & Festividades & Uma vez por ano \\
\hline
\end{tabular}

Quadro 2 - Manifestações culturais e eventos existentes no bairro do Catolé

Os eventos oferecidos pela SAB atraem a população do bairro em geral. Nestes, são realizados distribuição de brindes, passeios, lanches, serestas, aumentando, assim, o interesse e participação da comunidade, que muitas vezes só vem à $\mathrm{SAB}$ por meio desses eventos.

Talvez a população não vá às reuniões mensais da SAB Catolé, por acreditar que sua presença, nas reuniões, não irá contribuir para um melhor funcionamento do bairro. Já nos eventos, existe algo imediato a receber, motivando assim a sua presença.

No carnaval, há alguns anos, é desenvolvido um trabalho com as crianças, no qual é realizado o "Boi de Carnaval". Um boi identificado, 
no bairro, foi o "boi dengoso" (NASCIMENTO; LEMOS, 2006). As crianças, com a ajuda de moradores do bairro, confeccionam suas fantasias, utilizando o espaço da SAB ou a quadra para ensaios e se apresentam, nas ruas do próprio bairro do Catolé, no período carnavalesco. Esses eventos são realizados com recursos dos próprios moradores.

As brincadeiras de rua também se caracterizam como manifestações culturais e estão presentes no cotidiano do bairro do Catolé. A rua é um espaço de partilha tanto do aprendizado quanto da interação entre as crianças. Essas brincadeiras têm intuito de manter viva a história, as tradições e as raízes de uma cultura (ZACARIAS, 1999).

Dessa forma, apontamos a necessidade de políticas públicas de lazer, que propiciem a preservação das brincadeiras de rua como a amarelinha, as competições de bola de gude e a pipa, observadas no cotidiano lúdico do Catolé.

\section{Considerações finais}

Em linhas gerais, são notórios os paradoxos existentes no Catolé. Por um lado, inúmeras formas de lazer são ligadas ao consumo. Por outro lado, percebemos a desigualdade na distribuição dos espaços e equipamentos públicos de lazer do bairro, visto que por ter uma grande extensão territorial, talvez alguns dos seus próprios moradores não tenham condições de se deslocarem para esses lugares.

Para que as atividades de lazer futuramente não estejam apenas vinculadas ao consumo, devido ao crescimento de espaços privados de lazer e a deficiência da infraestrutura de espaços públicos, é preciso que a sociedade seja participante na construção do direito ao lazer para todos os cidadãos, para que dessa forma, o lazer possa contribuir para a transformação social.

Parafraseando Maia e Costa (2008), é necessário que as prefeituras, secretarias e órgãos públicos, de forma geral, procurem saídas para que os espaços públicos de lazer tenham as transformações e adaptações viáveis às necessidades da população. Para tanto, é funda- 
mental uma melhor atenção da sociedade quanto às políticas públicas em geral da cidade.

Neste sentindo, torna-se importante uma melhor comunicação entre os órgãos governamentais, para juntos construírem uma melhor elaboração de políticas públicas voltadas ao lazer, que beneficiem toda a comunidade. Através do contato com a SAB do Catolé, percebemos a existência de moradores que ainda acreditam em suas reivindicações, que são de suma importância para mostrar às autoridades suas necessidades quanto ao lazer, dentre outras necessidades.

Portanto, torna-se essencial que os gestores, em geral, tenham conhecimento da importância do lazer e das reivindicações da população, de forma a estabelecer parcerias entre a comunidade e o poder público, principalmente para a conservação dos espaços e equipamentos de lazer (CHEMIN, 2007).

Em síntese, é necessário discutir e fomentar políticas públicas que propiciem uma educação para o lazer, de forma que os indivíduos reflitam e ocupem o seu tempo livre da melhor maneira possível, reconhecendo o cidadão ao seu lado não como um estranho ou um inimigo, mas como alguém que, apesar de diferente, pode caminhar junto conosco, em direção ao bem comum.

\section{Referências}

BAUMAN, Z. Confiança e medo na cidade. Tradução Eliana Aguiar. Rio de Janeiro: Jorge Zahar, 2009.

BETTI, M.; ZULIANI, L. R. Educação Física escolar: uma proposta de diretrizes pedagógicas. Disponível em: <http://www.mackenzie.br/fileadmin/Graduacao/CCBS/Cursos/Educacao_Fisica/REMEFE-1-1-2002/ art6_edfis1n1.pdf>. Acesso em: 03 fev 2009.

CHEMIN, B. F. Políticas públicas de lazer: o papel dos municípios na sua implementação. Curitiba: Juruá, 2007. 
IBGE - Instituto Brasileiro de Geografia e Estatística. Censos Demográficos 1991/2000. 2002.

INSTITUTO ALPARGATAS. Projeto Escola Ideal. Disponível em: <http:// www.institutoalpargatas.com.br/index.php?escola-ideal_4>. Acesso em: 14 abr 2009.

JORNAL DA PARAÍBA. Catolé já se consolida como pólo comercial e de entretenimento. Jornal da Paraiba. 11 de Junho de 2006.

MAIA, L. F. S.; COSTA, L. K. S. A auto-organização comunitária e o trabalho coletivo dos usuários do Programa Esporte e Lazer da Cidade: um olhar sobre a realidade dos núcleos de Natal.Seminário O Lazer em Debate, 9., 2008 São Paulo, Anais... São Paulo, 2008. CD-ROM.

MARCELlinO, N. C. Lazer e Humanização. Campinas: Papirus, 1995.

MELO, V. A.; ALVES JÚNIOR, E. D. Introdução ao lazer. Barueri: Manole, 2003.

NASCIMENTO, S. Q.; LEMOS, E. M. B. C. A dança popular nas comunidades de bairro: conhecendo a arte dançante em Campina Grande. Campina Grande: PIBIC/CNPq/UEPB, 2006.

RECHIA. S. A política de lazer na cidade: em pauta: “a análise da gestão dos espaços em distintas realidades e segmentos populacionais. Encontro Nacional de Recreação e Lazer,20., 2008, São Paulo. Anais... São Paulo, 2008. CD-ROM.

TORO, J. B.; WERNECK, N. M. D. Mobilização social: um modo de construir a democracia e a participação. Belo Horizonte: Autêntica, 2007.

União Campinense das Equipes Sociais. Estatuto. Campina Grande, 2006. Disponível em: < http://www. ucescg.com.br/estatutos.html> Acesso em: 18 jan 2009.

ZACARIAS, L. S. Crianças no mundo da rua: socialização, cultura e gênero. Dissertação (Mestrado) - Universidade Estadual de Campinas, Faculdade de Ed. Física. Campinas, 1999. 


\title{
Pedregal, a dimensão educacional do lazer contribuindo para uma nova perspectiva de vida
}

\author{
Tiago Lopes Bezerra \\ Cheng Hsin Nery Chao
}

O bairro Pedregal demonstrou, no seu surgimento, uma intensa busca para a construção da comunidade, os moradores se relacionavam unindo forças em prol da coletividade. Porém o crescimento do bairro ocorreu de forma desordenada acarretando consequências como: falta de saneamento e espaços de moradia. Hoje, devido às adversidades do bairro, entende-se a necessidade de se aliar na busca de um melhor crescimento para o bairro. Neste sentido, a cultura, o esporte e o lazer têm contribuído de forma especial.

Neste bairro, devido à escassez de equipamentos como praças e quadras, a prática do esporte recreativo é feita dentro das escolas, até mesmo por uma questão de segurança, pois, nas ruas, as crianças ficam vulneráveis à violência.

No aspecto do lazer, devido à deficiência de espaços específicos para sua vivência, e os que existem apresentarem péssimas condições de uso, a rua acaba sendo importante local de encontro para adultos, que por sua vez tomam conta das mesmas com as "conversas de calçadas", momento que os moradores vão para frente de suas casas carregando "banquinhos" para passar o tempo conversando e jogando cartas, dominó, etc. Mas a rua também se tornou um lugar onde ocorre o tráfico de drogas, a prostituição, e quase sempre esses momentos de 
encontros acontecem em meio a bebidas alcoólicas ingeridas, de forma excessiva, provocando um descontrole psíquico, o que tem proporcionado atos de violência.

Já no que diz respeito à cultura, o bairro apresenta manifestações relacionadas a datas comemorativas como o Carnaval e o São João, a comunidade se mobiliza e se organiza para desfrutar das festas.

Segundo o diretor da escola Manoel da Costa Cirne, referência no bairro, os moradores reconhecem a necessidade da cultura, do esporte e do lazer como forma de edificação social no sentido de educar e, sendo assim, buscam pela formação de eventos culturais, esportivos e espaços de lazer, e eles encontram, como fortes aliadas para construção de tais eventos, a escola que serve como fonte primária de educação e a $\mathrm{SAB}$, como auxílio na união da comunidade.

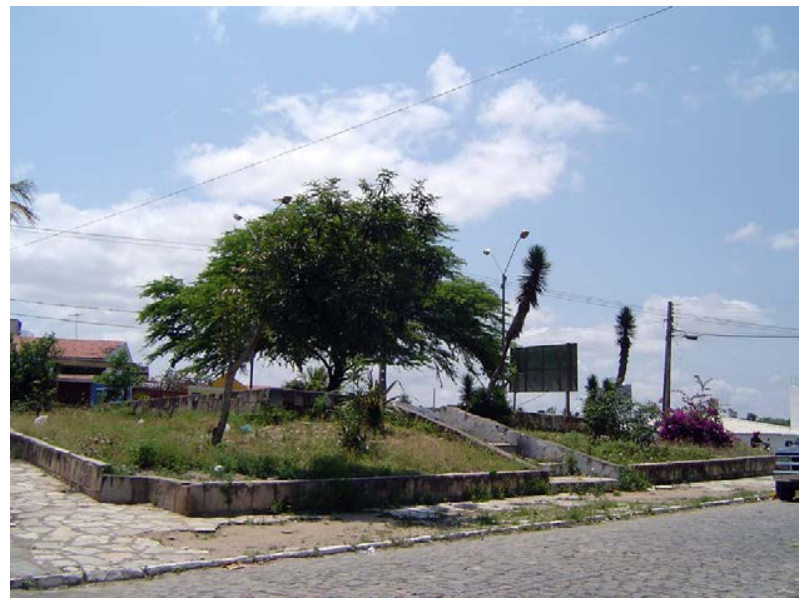

Imagem 01: Única praça do bairro.

Fonte: Arquivos GCEM 


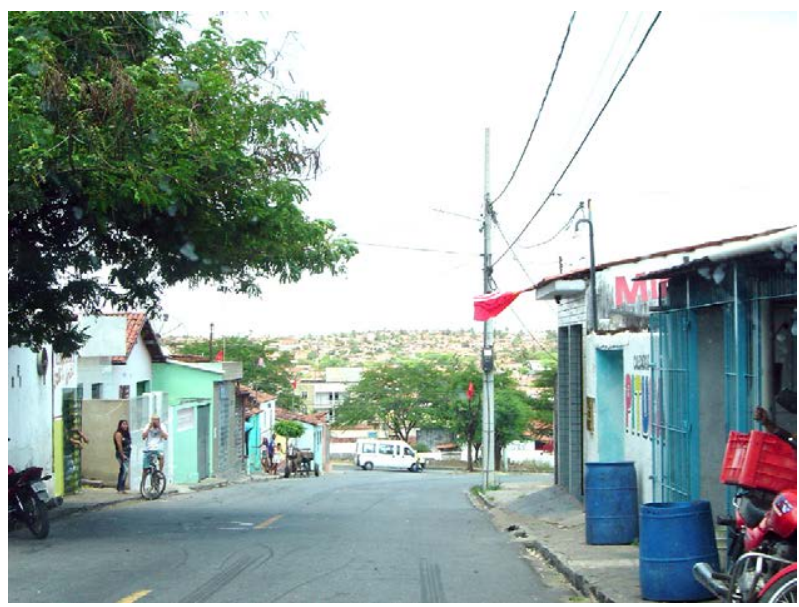

Imagem 02: Uma das ruas principais do bairro, onde o hábito das "conversas de calçada" são comuns

Fonte: Arquivos GCEM

\section{Caracterização do bairro}

O bairro do Pedregal está localizado na zona oeste da cidade de Campina Grande e surgiu por meio de uma invasão. No surgimento do bairro, no ano de 1975, existiam apenas 39 casas. De acordo com dados do IBGE (2002), a população é de 9.267 habitantes, sendo 4.569 homens e 4.698 mulheres, porém estima-se que já há mais de 12,5 mil habitantes no bairro, pois o seu crescimento tem sido rápido. A comunidade do Pedregal é, em sua maioria, constituída por pessoas carentes. $O$ rendimento médio mensal do bairro é de $\mathrm{R} \$ 206,11$ (duzentos e seis reais e onze centavos).

Segundo o presidente da SAB do Pedregal, o prefeito da cidade de Campina Grande, na época, ajudou o surgimento do bairro na desapropriação da área, na construção de casas e também no projeto de urbanização ${ }^{1}$. Foram desenvolvidas algumas obras, como: eletrificação de parte do bairro, construção de uma escola, uma lavanderia comuni-

1 Nessa fala percebe-se que o entendimento de poder público ainda é falho, a figura do prefeito é vista como alguém que faz favor, não como um agente administrativo que representa o povo e deve direcionar verbas e garantir o direito dos cidadãos. 
tária, posto de polícia, uma creche e a sede da SAB. Mas atualmente a realidade é outra.

O bairro apresentou um crescimento desordenado e tumultuado com a chegada de novos moradores, também, com um poder aquisitivo baixo e falta de conhecimento de ordenamento urbano, sendo assim se alojaram onde encontraram espaço.

Conforme Santos (2002), muitas periferias podem ser consideradas de "espaços opacos", definidas desta forma, pois são locais onde as políticas públicas (saneamento, coleta de lixo, policiamento, etc.) não chegam. As pessoas são marginalizadas pela falta de aplicação de políticas públicas, por parte do poder público que forneça melhores condições humanas de vida, seja ali ou de onde vieram.

0 território do bairro, geograficamente falando, sofreu com esse crescimento, pois foi submetido a uma situação caótica, onde o que importava para a população era ter uma moradia, o que resultou em falta de saneamento adequado, de ruas pavimentadas e estruturas de terreno para a construção de casas para atender essa crescente ocupação. Hoje se espera reformas urbanas, no bairro, para melhores condições de vida, porém esta aparentemente esquecido pelas autoridades governamentais.

\section{A escola}

O bairro Pedregal apresenta 3 (três) escolas, a Escola Municipal Deputado Petrônio Figueiredo, a Escola Municipal Manoel da Costa Cirne e a Escola Municipal e Estadual Leonardo Viturino Guimarães.

A escola escolhida para a pesquisa, considerando seus critérios, foi a Manoel da Costa Cirne, construída por volta dos anos de 1996 e 1997. 0 atual diretor assumiu em janeiro de 2007, mas antes do cargo, trabalhava, na escola, como professor de Educação Física desde 2003.

0 diretor da escola, baseando-se numa perspectiva emancipatória, entendendo que uma educação emancipacionista busca a perspectiva da pedagogia crítica, como forma de intervenção no mundo, possibi- 
litando mudança, consciência, liberdade, esperança e autonomia, na vida em sociedade (FREIRE, 2007), apresenta um método pedagógico favorável para um desenvolvimento educacional, principalmente através de projetos.

Por meio desses projetos, a escola tem conseguido atrair parcerias bastante produtivas, como por exemplo, o projeto judô, conseguindo junto a uma rede privada de supermercados um investimento, no segundo semestre do ano de 2007, de cerca de $\mathrm{R} \$ 9.410$ (nove mil quatrocentos e dez reais), além de 70 (setenta) quimonos, os tatames, inscrições em competições, as faixas. 0 objetivo é expandir por toda a comunidade, não só para os alunos da escola. Também apresentam parcerias com profissionais da área de Educação Física que atuam como voluntários, na escola, dando aulas de Taekwondo e xadrez. Assim a escola vai crescendo e tende a contribuir para um melhoramento da comunidade.

Quando perguntado sobre a captação de recursos, o diretor da escola diz receber, para manutenção da escola, do PDDE (Programa Dinheiro Direto na Escola) R 7.000 (sete mil reais) que é para aquisição de imobiliário, material de limpeza, material de expediente e diz ter que se "desdobrar" para fazer esse dinheiro render. Recebe mensalmente a verba do projeto PNAE (Programa Nacional de Alimentação Escolar) destinada à merenda, e foi contemplado com o PDE (Programa de Desenvolvimento da Escola). Já concluiu o PDE e está aguardando uma verba de $\mathrm{R} \$ 31.800$ (trinta e um mil e oitocentos reais), onde a Educação Física foi contemplada com quase R\$ 5.000 (cinco mil reais).

Percebe-se, através desse relato, que as verbas chegam, mas o valor montante é muito menor do que a necessidade real da escola, visto que são verbas anuais e a escola apresenta turnos pela manhã, tarde e noite precisando de um investimento contínuo para manutenção da instituição como: estrutura de prédio e limpeza. Desta forma, a verba torna-se pouca para a construção de qualquer área de lazer. A escola está encontrando na comunidade, a ajuda necessária para manutenção do prédio. Pais de alunos que são pedreiros e serventes de pedreiros ajudam a reformar a escola com trabalho voluntário. 
Como depende da comunidade para obter espaços específicos de lazer, a escola apresenta uma deficiência nesse aspecto, pois as pessoas nem sempre estão disponíveis, sendo assim, a escola oferece somente uma sala de judô em construção, um minicampo em condições precárias e um pátio coberto. Isso significa pouco, partindo da ideia que esses espaços são como uma área planejada para uma determinada ação com objetivo de aprimorar comportamentos. Atenta-se ao cuidado de não cair na armadilha evidenciada por Stucchi (1997, p.105),

estes espaços, culturalmente são dados para que as pessoas apresentem comportamentos de acordo com movimentos produtivos, dependendo da condição física, mental e social, para que possam aprender e raciocinar o espaço, relacionar-se e se movimentar, para uma linha de produção dentro de um sistema.

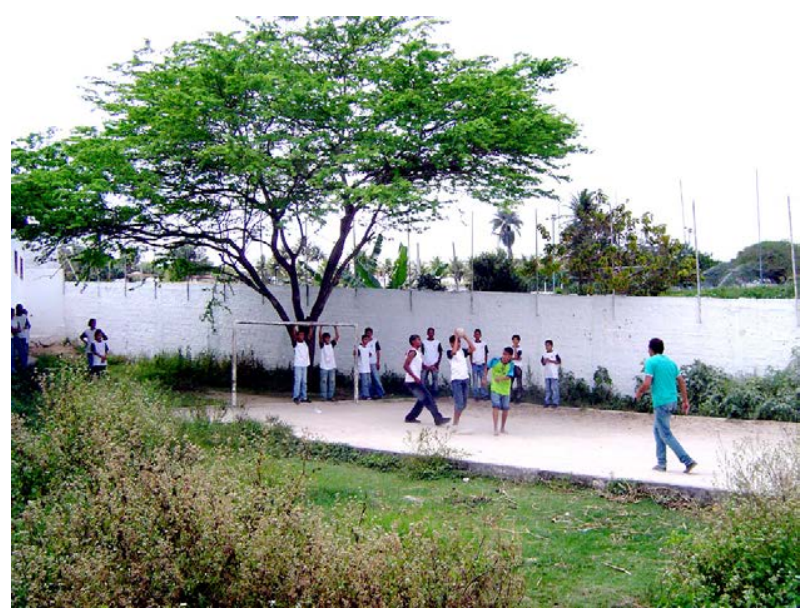

Imagem 03: Quadra de futebol 


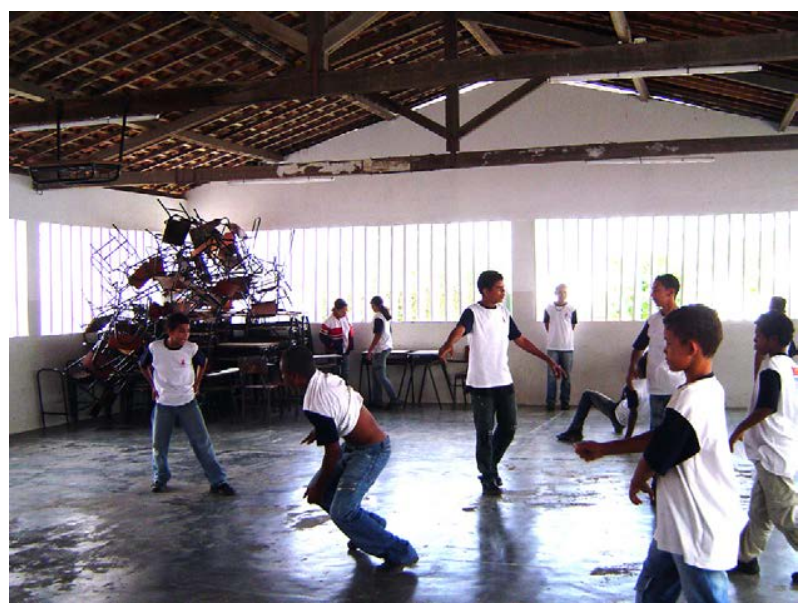

Imagem 04: Pátio coberto

Fonte: Arquivos GCEM

A comunidade participa por considerar os projetos da escola de extrema importância para os alunos. Por isso, a escola precisa realizar atividades recreativas com fundamentos relacionados com o lazer, apresentando atividades com objetivos, pois... "nas tentativas de adaptação dos valores vivenciados no lazer com a prática educativa, tem-se confundido a orientação e a motivação, com um simples 'deixar fazer'" (MARCELLINO, 2007, p. 97).

É essencial que esses trabalhos vividos, na escola, apresentem um caráter educativo, por que..."existe uma relação pedagógica e querer camuflá-la ou omitir-se enquanto educador é bem pior do que explicitá-la" (MARCELLINO, 2007, p. 98). A vivência da escola nos mostra que as atividades realizadas buscam promover o desenvolvimento das crianças através da obtenção de conhecimento, agindo numa pedagogia dominante, relatada por Paulo Freire (2007) no seu livro Pedagogia do Oprimido.

Essa pedagogia dominante é fundamentada em uma concepção bancária de educação, onde predominam o discurso e a prática, na qual, quem é o sujeito da educação é o educador, sendo os educandos, como "vasilhas a serem enchidas"; o educador deposita informações que os educandos recebem, memorizam e repetem. 
No caminho contrário, a escola Manoel da Costa Cirne evidencia a pedagogia transformadora de Freire, que tem sido vivida através de projetos com cunhos pedagógicos que visam fornecer um desenvolvimento dos educandos, compreendendo sua realidade e, através do conhecimento apreendido, podendo contribuir com sua comunidade.

0 diretor da escola diz ter um projeto piloto no qual denominou de "Lugar de criança é na escola”, onde através de subprojetos financiados, ou com a ajuda de voluntários, torna-se uma realidade que a comunidade está buscando, a cada dia, e a própria escola tem se equipado em conhecimento para atrair essas crianças no contra turno de aula delas.

Mesmo sem apresentar tantos atributos em se tratando de estrutura e espaços, o diretor está atraindo as crianças com projetos e atividades que trazem crescimento para a escola e que despertam os interesses das crianças, como um projeto que a escola propôs e que foi aprovado pelo MEC, através do PROINFO - Programa Nacional de Informática na Educação, conseguiu o laboratório de informática que vem com dez computadores. 0 diretor deseja que, a cada dia, as crianças sejam contempladas com atividades esportivas e através disso, movimentar, socializar os alunos além da sala de aula.

A discussão das festividades, a confecção de adereços, fantasias e organização dos eventos são outras ações que têm dado muito certo. O lazer aí presente, tende a afastar o sentido de cumprir a atividade apenas por construir, vivenciando prazerosamente a arte de adquirir conhecimentos e desenvolvendo a sociabilidade. Fator considerado essencial pelo diretor que afirma ser o social mais importante do que a aprendizagem.

Associando os dois fatores, obtemos benefícios imensuráveis, como tirar as crianças das ruas e alimentá-las com conhecimentos e interações sociais, diminuindo a criminalidade, o tráfico, a violência, o trabalho infantil, formando jovens e adultos conscientes e influenciadores de seu meio.

0 autor Norbert Elias (1996) defende que o jogo ${ }^{2}$ é um modelo metodológico que ajuda na compreensão das configurações e interde-

2 Elias, na maioria dos seus estudos, tem focado sua atenção nos aspectos do esporte e do jogo como um processo civilizador. 
pendências numa sociedade. 0 lazer tem este aspecto de sociabilidade, que não lhe é exclusivo, onde vão aflorar ações motoras, o imaginário e o emocional humano.

Muitos desejos se realizam no momento de descontração (ELIAS, 1996), desta forma, muitas crianças do bairro procuram estar presentes, na escola, envolvendo-se com as atividades oferecidas por ela, o que agrada muito aos pais. Eles têm colaborado com a escola por reconhecerem que as crianças encontram o que fazer participando nos projetos, preocupando menos em casa ${ }^{3}$, pois os pais vão ter a certeza de que seus filhos estão protegidos.

Além das atividades na escola, os pais encontram, na Universidade Estadual da Paraíba - UEPB, uma oportunidade educativa para os seus filhos através do Projeto Escolinha ${ }^{4}$, oferecido gratuitamente, com aulas de diversas modalidades esportivas e artístico - cultural.

Porém uma minoria consegue desfrutar desse projeto pelo motivo dos pais terem que trabalhar no horário da realização do projeto e assim não conseguem levar seus filhos. De um total de 339 (trezentos e trinta e nove) alunos inscritos no projeto, apenas 23 (vinte e três) são do Pedregal, um número muito pequeno considerando a proximidade do bairro e a importância do Projeto de tirar as crianças das ruas para educar através do esporte e das atividades artísticas - culturais afastando-as da violência, um dos pontos críticos do bairro.

A sociedade está educando as crianças no lugar dos pais, como bem entende. Milton Santos (2001) trata da violência e diz: "A violência dá impressão de ser incontrolável, mas não é irreversível". E afirma que "a globalização também contribui para o aumento da violência. Sua idéia parte do princípio de que as pessoas sejam competitivas. Ao aceitarem a competição, elas são naturalmente estimuladas a ter um comportamento violento".

A escola está tentando mudar essa história, na comunidade do Pedregal, com atitudes consideradas pelos próprios pais dos alunos de revolucionárias. E nessa relação de segurança e violência, a escola bus-

3 Percebe-se que os pais acabam passando a responsabilidade de educar os filhos para a escola. 4 Laboratório pedagógico: Saúde, Esporte e Lazer. Departamento de Educação Física da Universidade Estadual da Paraíba. 
cou aliar-se àqueles que tentavam impedir o crescimento da mesma chamando-os para mostrar a importância da escola na vida deles e de seus filhos. Essas pessoas, mesmo sendo usuárias de drogas e agentes da criminalidade, estão apresentando preocupações com seus filhos, pois não querem o mesmo caminho para eles.

Sendo assim, ajudam a proteger a escola incentivando seus projetos e mostrando à comunidade o valor da educação. Hoje, muitas das pessoas que interferiram no crescimento da escola já colaboram na segurança da mesma que busca retribuir com atividades que possam trazer um conhecimento para as pessoas do bairro, incentivando a diminuição da violência.

Sendo assim, a escola sente liberdade de realizar seus eventos com manifestações culturais existentes na comunidade, referentes às datas festivas. Por exemplo, no carnaval, a escola realiza atividades que trazem a história da festa. Os professores ensinam às turmas a história da festa, com as marchinhas (músicas da época do carnaval dos anos 20 aos 60), com decorações carnavalescas e ainda a formação de blocos de carnaval em cada turma.

A figura característica desse evento é o boi-de-carnaval que é vivenciado com entusiasmo, pois já é uma tradição da cidade de Campina Grande. Quase todas as crianças do bairro têm um boi-de-carnaval que elas mesmas fabricam com a ajuda dos irmãos e pais.

Essa atividade desperta três dos interesses culturais do lazer classificados por Dumazedier (1980), o manual, o artístico e o social. Onde o manual expressa a atividade em que o trabalho com as mãos é observado de forma plena, o social quando os sujeitos se propõem a estar juntos, desfrutando de um prazer proporcionado pelo convívio e o artístico enquanto expressão da cultura local.

Quando um boi aparece na rua logo aparece uma grande quantidade de crianças ao redor dele que é acompanhado por uma batucada feita por elas. Cada boi tem o seu próprio nome. Os bois andam, nas ruas do bairro, levando alegria, cultura e tradição, e quando um boi encontra outro na rua pode surgir uma briga para mostrar quem é o boi mais forte. Isso movimenta a comunidade nas ruas. 


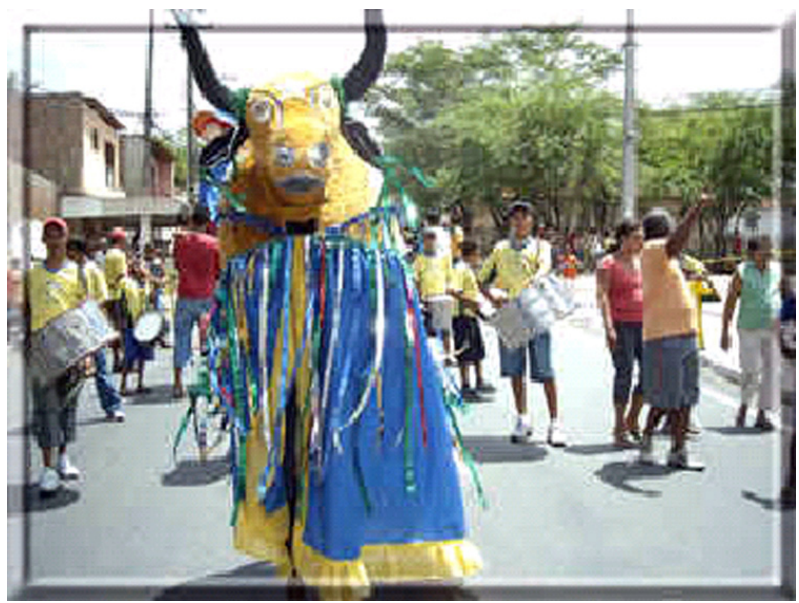

Imagem 05: Boi do carnaval seguido pela batucada

Fonte: www.carnavaldecampinagrande.com.br

Na época Junina, a escola realiza um desfile de carroças de burro, a "Burreata Neco Cirne", a festividade faz parte dos festejos de São João da cidade. $O$ evento é coordenado pelo diretor da escola e trouxe uma renovação cultural ao bairro. A "burreata” ocupa as principais ruas do bairro. Todas as carroças são ornamentadas pelos alunos e familiares.

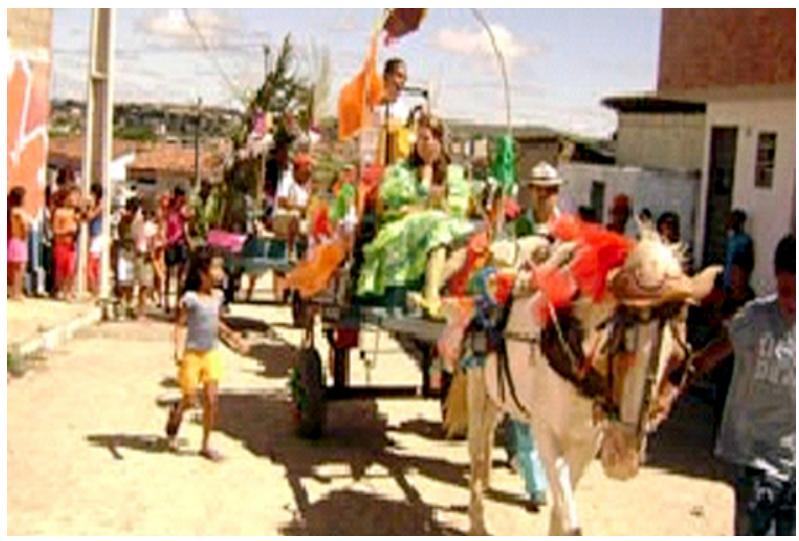

Imagem 06: Burreata nas ruas do bairro

Fonte: g1.globo.com/Noticias/Brasil 
A comunidade tem interagido com a escola por meio destes eventos promovidos por ela que traz parte dos moradores para dentro da mesma e isso é de grande benefício, por contribuir para uma política de boa vizinhança, diminuindo a violência, provocando uma melhor relação social e fornecendo aos pais o acompanhamento do processo educacional que seus filhos estão recebendo. Além de transformar as ruas do bairro em palco de apresentação cultural.

A realização de manifestações culturais e a tentativa de preencher o tempo livre dessas crianças têm ajudado os pais na educação dos filhos e mostrado aos alunos caminhos para uma vida sem a violência, o tráfico, a prostituição, etc. Mas a escola não pode tomar o lugar dos pais e nem da comunidade, por isso se faz necessário uma busca de um melhor relacionamento entre pais e filhos e um investimento na comunidade, que deve contar com a ajuda da SAB, que foi construída para melhorar suas condições sociais.

\section{SAB - Sociedade de Amigos do Bairro}

A SAB do bairro do Pedregal surgiu, no ano de 1980, e acompanhou toda a disputa política vivenciada pelo bairro na sua construção. A política partidária ainda está em vigor, pois o presidente atual não exerceu o mandato, no ano de 2008, por ser candidato ao cargo de vereador do município de Campina Grande. Nesse período, ficou sendo administrada por um responsável, que foi o fundador da SAB no bairro. Ela tem mais de 1.500 (um mil e quinhentos) sócios, com uma faixa de 2.000 (duas mil) famílias dentro do bairro, mas só que entre 40 (quarenta) e 50 (cinquenta) pessoas não estão, em dia, com a mensalidade. Isso pode prejudicar o andamento das funções da $S A B$, pois ela necessita de dinheiro para quitar as dívidas da instituição e o único fundo de rendas é por intermédio dos associados.

Existem, no local, parcerias para promover cursos para a comunidade. Um exemplo é o SENAI que, junto a Prefeitura da cidade, oferece cursos de qualificação profissional. A parceria oferece cursos que fazem parte das ações e atividades do eixo geração de trabalho e renda, 
no trabalho, de participação comunitária do Programa Habitar Brasil, do Município, com co-execução pela Caixa Econômica Federal, através de recursos provenientes da União (Governo Federal).

Entre os cursos oferecidos estão corte e escova, pedreiro, instalador de água e esgoto, marceneiro, corte e costura, montagem e manutenção de computador, uso de materiais recicláveis, confeccionador de calçados e artefatos de couros, mecânico de automóveis/injeção eletrônica, mecânico de motocicletas, padeiro e outros.

Outra ação da SAB junto à comunidade foi a realização de um abaixo assinado com 1960 (um mil novecentos e sessenta) assinaturas e um ofício direcionado ao prefeito da cidade de Campina Grande-PB, para trazer uma farmácia popular para o bairro. 0 projeto já foi aprovado pela câmara de vereadores, mas falta ser aprovado em Brasília para poder ser liberado e chegar até o bairro. Também já tentaram implantar uma biblioteca pública dentro da $\mathrm{SAB}$, mas o projeto não foi aprovado pela prefeitura, porém ela continua buscando benefícios para a comunidade, pois reconhece que a sua função é fornecer subsídios para o desenvolvimento do bairro.

A SAB tem realizado eventos que trazem informações básicas de saúde e de comércio, assim como festividades: Dia das Mães, Dia das Crianças, Dia dos Pais, mas é necessário que a comunidade compareça, não só nas festividades, reclama o atual dirigente. As assembleias realizadas uma vez a cada mês, são importantes para discutir as necessidades da comunidade. Na época da entrevista, somente uma média de 30 (trinta) pessoas estava comparecendo. No entanto, a SAB conquistou uma vitória para a comunidade, mesmo essa não se fazendo tão presente, foi a construção da creche pública Cotinha Carvalho com capacidade para 180 crianças, mantida pelo governo municipal.

A comunidade do Pedregal reconhece, através da influência da escola municipal, que o esporte, a cultura e o lazer são influentes para o crescimento de uma comunidade e busca, no bairro, espaços e equipamentos que favoreçam a prática desses elementos.

Porém, esses espaços se resumem a creche Cotinha Carvalho, a Casa da Ciranda e o Clube de Mães que apresentam boas condições de uso. No entanto, o bairro do Pedregal possui apenas uma praça e 
uma quadra que não apresentam boas condições. A comunidade ainda dispõe de uma praça no bairro Centenário, outra no Conjunto dos Professores e um campo no bairro Bodocongó, que são bairros vizinhos.

Um grande problema encontrado, no bairro, é a questão da saúde pública. Um levantamento feito pela Fapesq (Fundação de Apoio à Pesquisa do Estado da Paraíba), no local, confirmou o Pedregal como uma situação de calamidade pública: vários focos de mosquito, terrenos baldios usados como lixão e ruas com esgoto a céu aberto. Os moradores solicitaram que fossem colocados depósitos de lixo, nas ruas, que não são beneficiadas com a passagem do carro de lixo.

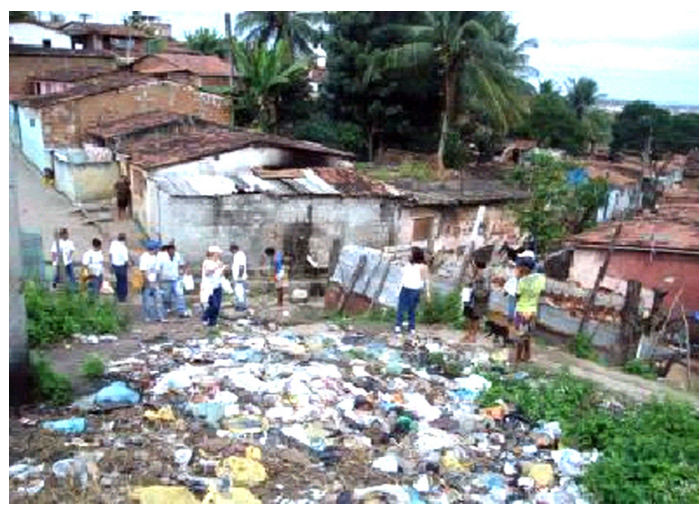

Imagem 07: Um dos terrenos públicos utilizados como depósito de lixo

Fonte: www.paulodetarsomedeiros.com.br/noticias25.html

A estrutura do bairro dificulta a passagem do carro do lixo, por ser constituído por muitos becos e vielas, além de um amontoado de gente vivendo em condições sub-humanas em barracos sem nenhuma estrutura de sustentação.

O tecido urbano do bairro do Pedregal é geograficamente denominado como caótico que é característica das áreas ocupadas desordenadamente, onde há ausência de lógica na disposição de quarteirões e traçados das ruas. (Atlas Geográfico do Estado da Paraíba, 2002), tal realidade destaca a falta de uma política urbana efetiva. 
Cerca de 150 famílias foram deslocadas, no ano de 2008, para bairros circunvizinhos como: Bela Vista, Monte Santo, Jeremias, Centenário, dentre outros para que pudesse ocorrer um trabalho de urbanização, com pavimentação das ruas que estão precárias, reforma do canal que tem mais de $1 \mathrm{~km}$ (um quilômetro) de extensão e a construção de saneamento básico para o bairro que apresenta esgotos a céu aberto, com córregos cortando as ruas e até casas.

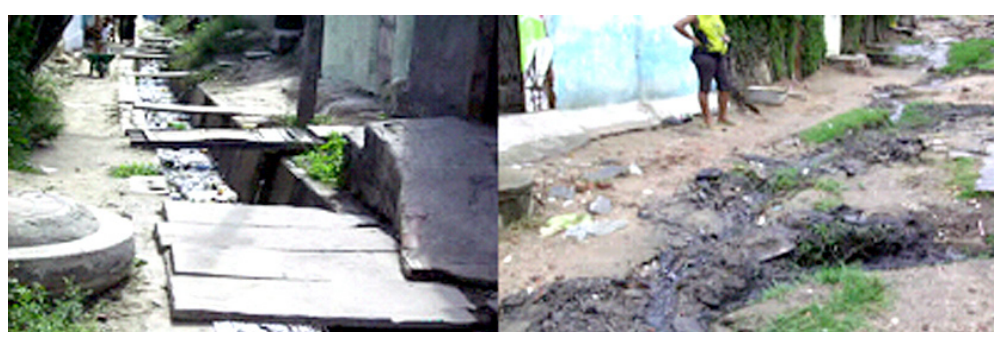

Imagem 08: Canal e esgoto a céu aberto

Fonte: www.paulomedeiros.com.br/noticias25.html.

Uma das justificativas apresentadas pela escolha de bairros vizinhos para o deslocamento das famílias, segundo o coordenador da Defesa Civil, é a de dar continuidade, sem maiores prejuízos, à rotina cotidiana dos moradores referente à escola das crianças e a ida para os locais de trabalho. Esse deslocamento é necessário, pois estas famílias estavam localizadas em áreas consideradas de risco nas proximidades do Canal do Pedregal.

Além da urbanização do canal do Pedregal, que será beneficiado com serviços de cobertura e elevação das paredes, o bairro estará recebendo outros benefícios como drenagem pluvial e esgotamento sanitário. Foram prometidas reformas a serem realizadas na SAB, no Posto Policial e no Clube de Mães.

Para melhorar a situação do bairro, está projetada a construção de uma escola padrão com capacidade para 320 (trezentos e vinte) alunos por turno, com 08 salas de aula, refeitório, banheiros, cozinha e uma área de recreio coberta, segundo informações do engenheiro da SOSUR (Secretária de Obras e Serviços Urbanos) responsável pelas obras. 
Mesmo sem prazo determinado, este mesmo engenheiro falou ${ }^{5}$ que através do Programa Habitar Brasil do governo federal, cerca de 70 unidades habitacionais serão construídas, além da recuperação de mais 420 unidades habitacionais em todo o bairro, incluindo a já concluída construção de uma quadra esportiva, no grupo novo, buscando incentivar a prática esportiva no bairro.

A prática esportiva da comunidade se resume ao futebol tanto masculino, quanto feminino praticado no mesmo campo de "várzea", que é o campo localizado no bairro Bodocongó. A SAB não tem envolvimento esportivo com a comunidade, não realiza campeonatos e nem investe em escolinhas esportivas, como não existem campos, no bairro, e as quadras são dentro das escolas, tudo fica por conta delas.

Em relação à segurança, a SAB trouxe para a comunidade, através de ofícios, a presença de dois soldados da polícia militar para fazer a ronda do bairro que, durante vinte e quatro horas, revezam com outros policiais do batalhão. Isso tem garantido uma segurança parcial da comunidade, pois o nível de criminalidade presente, no Pedregal, ainda é considerado pelas autoridades militares como altíssimo.

0 responsável pela $\mathrm{SAB}$ reconhece que há muito ainda para se fazer pela comunidade, pois sabe quais são as obrigações da SAB para com a comunidade, mas relata sentir dificuldades para trabalhar por se ver sozinho em busca de um bairro melhor.

\section{Conclusões}

A escola municipal Manoel da Costa Cirne foi motivo de satisfação para a nossa pesquisa, pois tem colaborado para o entendimento da comunidade de que se pode crescer através da cultura, do esporte e do lazer, e isso foi constatado em suas ações que influenciam o bairro nos aspectos educacional, cultural e social. Em seus estudos, na década de 1970, Dumazedier (1999, p.166) afirmou:

5 Entrevista dada à Coordenação de Comunicação da Prefeitura Municipal de Campina Grande, http://www.snn.com.br/noticia/6558/14. Acessado em 18 junho 2009. 
Hoje, a população urbana tomou consciência do papel, no desenvolvimento cultural das cidades, da escolarização; acabamos de evocar as dimensões na 'explosão escolar' deste último decênio. Mas a escolarização não é hoje senão uma parte, cada vez mais contestada, do desenvolvimento cultural de uma cidade.

Desta forma, a escola não é a única instituição em condições de participar de mudanças na vida dessa comunidade, mas a parceria com outras instituições dos diversos setores sociais, e a própria representatividade comunitária são essenciais.

De acordo com o apresentado, na pesquisa, podemos notar a precariedade dos espaços de lazer existentes na comunidade, mesmo tendo presente, na constituição brasileira de 1988, que é direito do cidadão o acesso ao lazer. "Como direito social, o lazer deve constituir-se em demanda da população. Isto é, a população deve pautar o lazer como um dos aspectos importantes para a sua vida, o que normalmente se chama de bem-estar social" (SUASSUNA, et al, 2007; p.91).

$\mathrm{Na}$ análise do bairro do Pedregal, fica notório que o lazer apenas ganhará foco em algum programa de governo ou como uma ação específica, quando as necessidades básicas da comunidade, como: moradia, saneamento básico, saúde, educação, etc., forem realmente contemplados. Contudo, as poucas iniciativas, promovidas pela escola e pela $\mathrm{SAB}$, estão levando à comunidade a conscientização de que precisam se unir e se respeitarem, dando um primeiro passo para uma vida melhor, num processo de construção de valores, encontrando, na função social da escola, um alicerce para essa construção.

\section{Referências}

ALVES JUNIOR, Edmundo de Drummond; MELO, Victor Andrade de. Introdução ao Lazer. Barueri: Manole, 2003.

BOURDIEU, P. A economia das trocas simbólicas. In: Miceli, S. (Org.) A economia das trocas simbólicas. 3 ed. São Paulo: Perspectiva, 1987. 
. O Poder Simbólico. 3 ed. Trad de Fernando Tomaz. Rio de Janeiro: Bertrand Brasil, 2000.

BRAMANTE, Antonio Carlos. Transversalidade do Lazer na Educação e Cultura. Encontro Nacional de Recreação e Lazer., 18., 2006, Curitiba. Anais... Curitiba, 2006. CD-ROM

BRUHNS, Heloisa Turini. Introdução aos Estudos do Lazer. Campinas: Editora da Unicamp, 1997.

COLETA SELETIVA. Disponível em: <www.ufcg.edu.br/.../COLETA\%20 SELEYIVA\%20NOS\%20BAIRROS\%20...>. Acesso em: 03 fev 2009.

BRASIL. Constituição (1988). Título II, Cáp. II, Dos Direitos Sociais. 1988.

DUMAZEDIER, Joffre. Sociologia Empírica do Lazer. São Paulo: 3ํㅡㄹção. Perspectiva S. A., 1999. . Valores e conteúdos culturais. São Paulo: Sesc, 1980.

ELIAS, Norbert. O processo civilizador. Rio de Janeiro: Zahar, ,1996.

FREIRE, Paulo. Pedagogia do Oprimido 46.ed. São Paulo: Paz e Terra, 2007.

ATLAS Geográfico do Estado da Paraíba. João Pessoa: Governo do Estado da Paraíba. 2002.

MARCELLINO, Nelson Carvalho. Lazer e Educação. Campinas: Editora Papirus, 2007,

PEDREGAL - CAMPINA GRANDE. Dispoínivel em: < http://pt.wikipedia. org/wiki/Pedregal_(Campina_Grande)>. Acesso em: 07 mar 2009. 
PREFEITURA MUNICIPAL DE CAMPINA GRANDE. Disponível em: < www.pmcg.pb.gov.br/transparencia/eixos/cidadania/91.php >. Acesso em: 18 jun 2009.

SANTOS, Milton. Entrevista à Folha de São Paulo; Revista Riopharma. São Paulo: maio/junho de 2001.

SOUZA, Thayze Barbosa de. Lazer, Trabalho e Educação: Percepções e Possibilidades de Emancipação Social dos Catadores de Lixo. Campina Grande: 2008.

STUCCHI, Sérgio. Espaços e equipamentos de recreação e lazer. In Bruhns, Heloísa Turini. Introdução aos Estudos do Lazer (Org). Campinas,SP: Ed. Unicamp, 1997.

SUASSUNA, Dulce Maria F. de A.; AZEVEDO, Aldo Antonio de. Política e Lazer: interfaces e perspectivas. Brasília: Thesaurus, 2007. 